\title{
PROCESSAMENTO E PROPRIEDADES DE COMPÓSITOS DE POLIAMIDA 6.6 REFORÇADA COM PARTÍCULAS DE VIDRO RECICLADO
}

Dissertação apresentada a Escola Politécnica da Universidade de São Paulo para obtenção do Título de Mestre em Engenharia.

Área de concentração: Engenharia de Materiais

São Paulo 
IRINA MARINHO FACTORI

\title{
PROCESSAMENTO E PROPRIEDADES DE COMPÓSITOS DE POLIAMIDA 6.6 REFORÇADA COM PARTÍCULAS DE VIDRO RECICLADO
}

\author{
Dissertação apresentada a Escola \\ Politécnica da Universidade de São Paulo \\ para obtenção do Título de Mestre em \\ Engenharia.
}

Área de concentração: Engenharia de Materiais

Orientador:

Prof. Dr. Samuel Marcio Toffoli

São Paulo

2009 
Ficha Catalográfica

Factori, Irina Marinho

Processamento e propriedades de compósitos de poliamida 6.6 reforçada com vidro reciclado. São Paulo, 2009.

$66 \mathrm{p}$.

Dissertação (Mestrado) - Escola Politécnica da Universidade de São Paulo. Departamento de Engenharia Metalúrgica e de Materiais.

1. Materiais compósitos poliméricos. 2. Vidro reciclado I.Universidade de São Paulo. Escola Politécnica. Departamento de Engenharia Metalúrgica e de Materiais. II. Título. 
"Verdade é a faculdade soberana da alma, a força espiritual por excelência, e pode mesmo dizer-se que é a essência da sua personalidade".

Léon Denis 


\section{Agradecimentos}

Ao meu esposo Edson, que sempre me incentivou e me apoiou e ao meu filho Arthur que é a minha motivação para caminhar sempre em frente.

Ao meu orientador e amigo Prof. Dr. Samuel Marcio Toffoli por toda a ajuda e pela oportunidade de poder fazer parte do seu grupo de pesquisas e assim poder desenvolver este trabalho.

À Saint Gobain Vidros do Brasil, especialmente a Mauro Arkeman que forneceu as amostras do vidro.

À Rhodia Poliamida e Especialidades Ltda. (Unidade de São Bernardo do Campo), especialmente a Gisela Perez Gesteira, pela utilização dos recursos disponíveis nos seus laboratórios.

Ao Núcleo de Tecnologia em Cerâmica da escola SENAI especialmente a Mauricio Batista de Lima.

Aos professores Hélio Wiebeck e Nicole R. Dermaquette pelas valiosas críticas e sugestões durante a qualificação.

Aos meus queridos amigos e colaboradores Adevaldo Rodrigues, Cleverson Vanzin, Daniela Gomes, Enos Coutinho, João Paulo Morgueto e Talita Mosaner pelo apoio e dedicação.

Aos meus pais Roberto e Irene e a minha irmã Carina, por estarem sempre ao meu lado.

À minha amiga Jupira que sempre acreditou no meu sucesso.

A todos que contribuíram direta ou indiretamente. 


\section{Resumo}

A poliamida 6.6 é um dos mais importantes membros da família das poliamidas, principalmente pelas excelentes propriedades de engenharia, como desempenho mecânico e térmico. A sua área de aplicação é ampliada pela adição de cargas inorgânicas. Dentre estas cargas podemos destacar as fibras de vidro, talco, wollastonita e micro esferas de vidro, cargas estas industrialmente conhecidas. Por outro lado, partículas de vidro reciclado provenientes de descarte nunca foram estudadas como reforço de poliamida 6.6, em especial as partículas menores, que são rejeitadas na reciclagem pela indústria do vidro por apresentarem dificuldade de transporte para os fornos, podendo depositar-se nos refratários (fenômeno de arraste), aumentando sua taxa de corrosão, assim reduzindo a vida útil dos fornos. Além disso, essas partículas têm formato irregular. Desse modo, compósitos de poliamida 6.6 reforçados com porcentagens variadas de vidro reciclado e cargas usualmente empregadas pela indústria foram processados em laboratório, com o auxílio de uma extrusora dupla-rosca e as amostras avaliadas foram obtidas por injeção. As seguintes propriedades dos compósitos foram avaliadas: resistência à tração, alongamento na ruptura, módulo na tração, resistência ao impacto Charpy sem entalhe, estabilidade dimensional e microscopia eletrônica de varredura. Os resultados indicam que é possível utilizar-se partículas de vidro reciclado numa matriz de PA-6.6 uma vez que as propriedades do compósito final são compatíveis com aquelas proporcionadas pelas cargas comerciais usualmente empregadas. 


\begin{abstract}
Polyamide 6.6 is one of the most important members of the polyamide family, mainly for its excellent engineering properties such as good mechanical and thermal performances. Its application area is enlarged by the addition of inorganic fillers. Among these fillers, glass fibers, talc, wollastonite and glass microspheres could be highlighted, which are industrially known fillers. On the other hand, glass particles from glass cullet have never been studied as a polyamide reinforcement, specially the smaller particles, which are rejected by the glass industry because of the carry-over phenomenon, increasing the cost of the smoke washing, as well as the possibility of increasing refractory corrosion, therefore reducing the useful life of the furnaces. Furthermore, these particles present irregular shapes. In this research, polyamide 6.6 composites, reinforced with different percentages of recycled powder glass and other common fillers used by the industry, were processed in laboratory scale with the help of a doublescrew extruder. Specimens for testing were obtained by injection, and the following composite properties were evaluated: tensile strength, elongation at rupture, elastic modulus, notchless Charpy impact strength, and dimensional stability. The specimens were also observed in a scanning electron microscope. The results indicated that it is possible to use particles of recycled glass in a PA6.6 matrix, once the final composite properties are compatible to the ones of composites containing usual commercial fillers.
\end{abstract}




\section{SUMÁRIO}

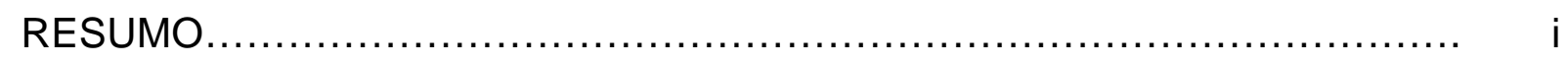

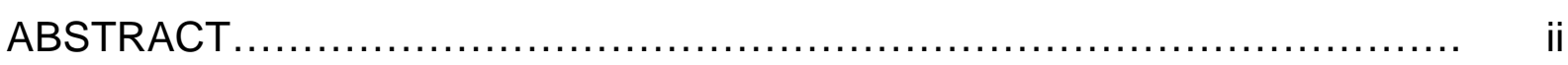

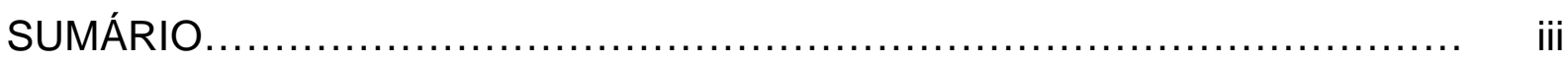

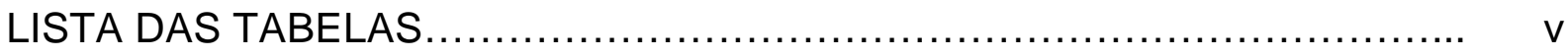

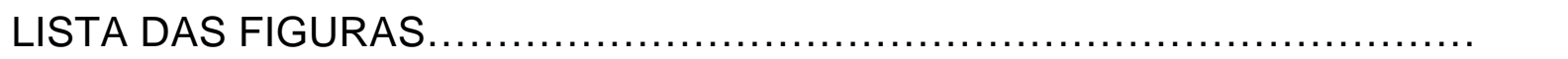

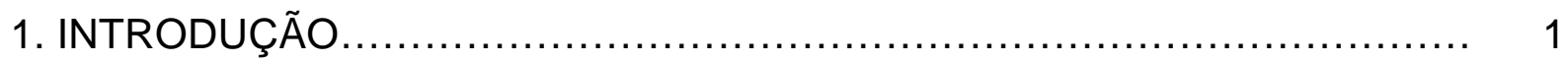

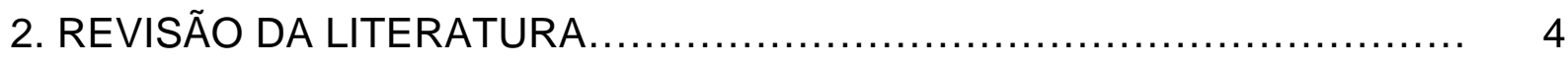

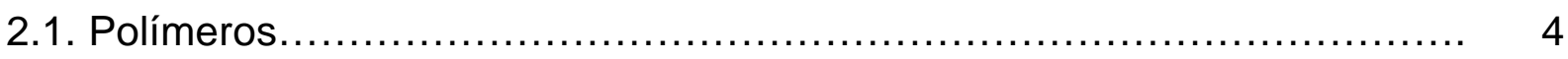

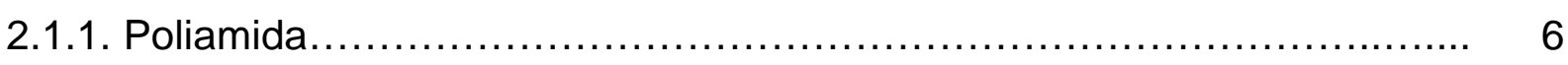

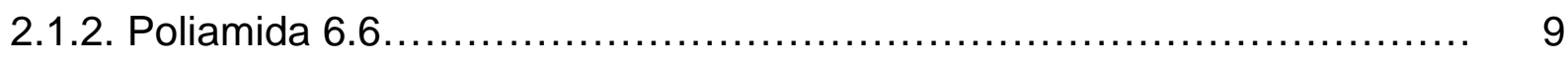

2.2. Cargas e reforços...................................................... 12

2.2.1. Talco

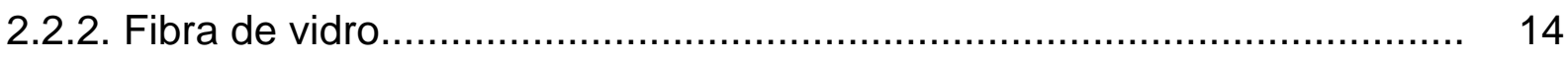

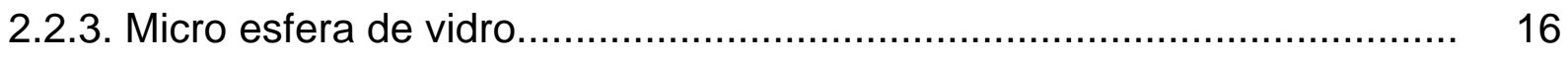

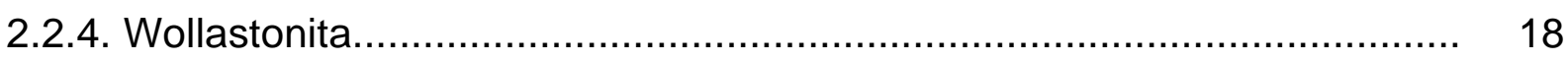

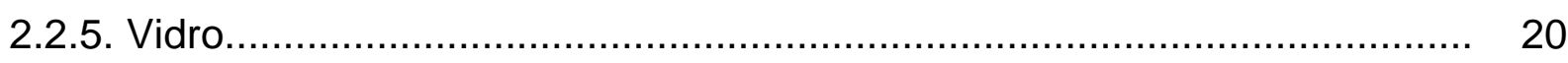

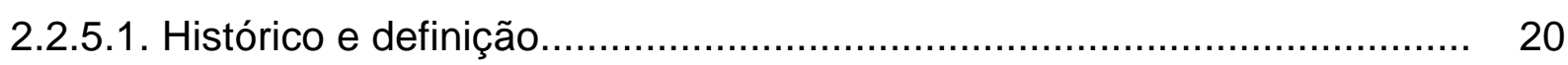

2.2.5.2. Composição e propriedades........................................................... 21

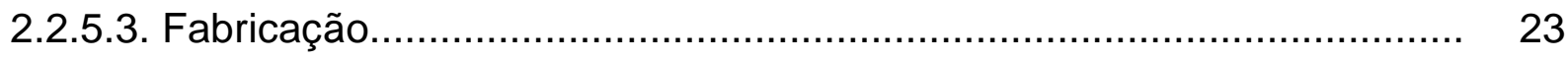

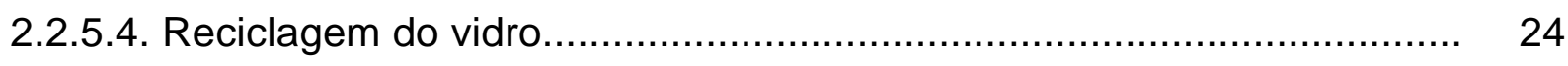

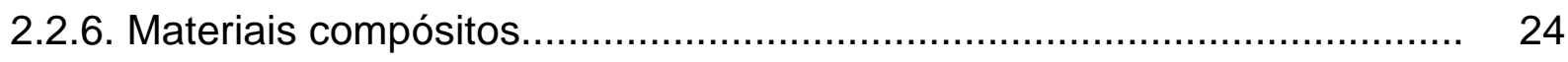

2.2.6.1. Compósitos poliméricos................................................................ 25

2.2.6.2. Preparação de compósitos termoplásticos.......................................... 26

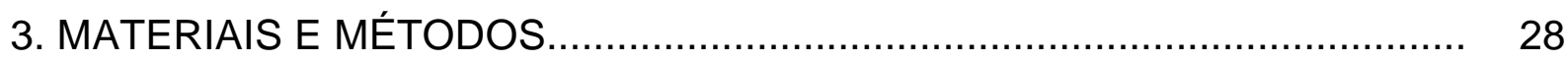

3.1. Descrição dos materiais..................................................................... 28

3.1.1 Poliamida 6.6 - Technyl A200 Natural............................................... 28

3.1.2. Cargas e reforços comerciais........................................................... 28

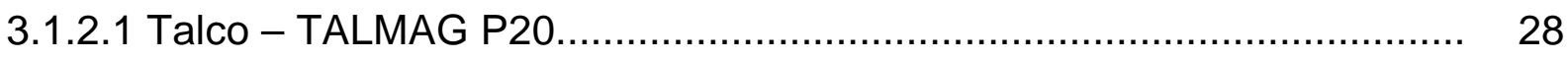

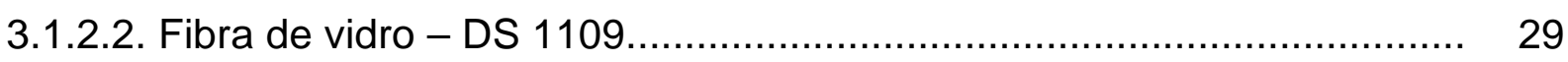

3.1.2.3. Micro esfera de vidro -3000 CP0302 ........................................... 29

3.1.2.4. Wollastonita - 10 WOLLASTOCOAT ............................................... $\quad 30$ 
3.1.2.5. Caco de vidro.

3.2. Descrição dos métodos.......................................................................... 31

3.2.1 Obtenção e moagem do caco de vidro.................................................. 31

3.2.2. Preparação dos compósitos (Extrusão)................................................ 32

3.2.3. Injeção dos corpos de prova............................................................ 34

3.3. Técnicas de Caracterização........................................................ 35

3.3.1. Análise de distribuição do tamanho de partículas........................... 35

3.3.2. Avaliação da interação da poliamida 6.6 e carga mineral por microscopia eletrônica de varredura (MEV) .........................................

3.3.3. Propriedades mecânicas........................................................... 36

3.3.3.1. Ensaios de resistência à tração, módulo de elasticidade na tração e alongamento........................................................................... 36

3.3.3.2. Ensaios de resistência ao impacto.............................................. 38

3.3.4. Determinação do teor de carga..................................................... 38

3.3.5. Determinação da estabilidade dimensional.......................................... 38

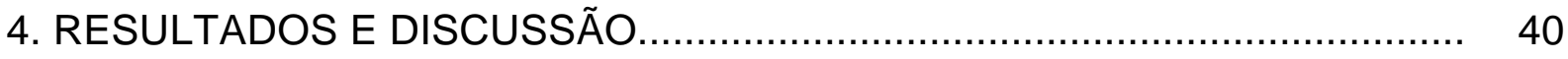

4.1. Análise do caco moído............................................................................ 40

4.2. Determinação do teor de carga ......................................................... 41

4.3. Avaliação de propriedades mecânicas....................................................... 42

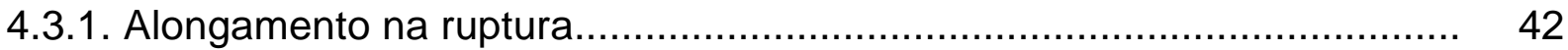

4.3.2. Resistência à tração na ruptura ...................................................... 44

4.3.3. Módulo de elasticidade na tração...................................................... 45

4.3.4. Resistência ao impacto Charpy (sem entalhe) ..................................... 47

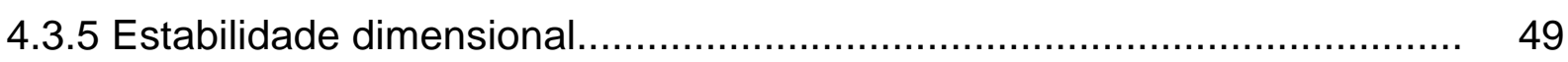

4.3.6 Microscopia Eletrônica de Varredura (MEV)........................................... 52

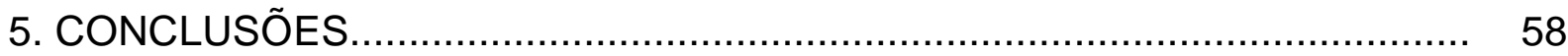

6. REFERÊNCIAS BIBLIOGRÁFICAS........................................................ 59 


\section{LISTA DAS TABELAS}

Tabela 2.1: Classificação das cargas ou reforços .......................................... 12

Tabela 2.2: Composições típicas de diversos vidros comerciais ...................... 23

Tabela 3.1: Características do polímero empregado ....................................... 28

Tabela 3.2: Valores típicos de composição do Talco TALMAG P20 ................. 29

Tabela 3.3: Valores típicos de granulometria do Talco TALMAG P20 ............. 29

Tabela 3.4: Propriedades típicas da fibra de vidro DS 1109 ............................ 29

Tabela 3.5: Propriedades típicas da micro esfera de vidro 3000 CP0302 ........ 30

Tabela 3.6: Valores típicos de diâmetro das partículas da micro esfera de vidro 3000 CP0302 ….............................................................. 30

Tabela 3.7: Composição química típica da wollastonita 10 Wollastocoat .......... 30

Tabela 3.8: Propriedades típicas da wollastonita 10 Wollastocoat ...................... 31

Tabela 3.9: Composição química do vidro ................................................. 31

Tabela 3.10: Composição dos compósitos poliméricos obtidos na primeira

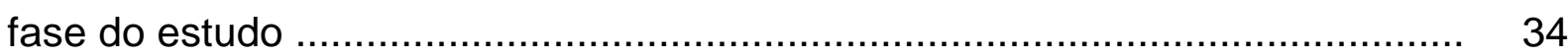

Tabela 3.11: Composição dos compósitos poliméricos obtidos na segunda fase do estudo

Tabela 4.1: Distribuição do tamanho de partícula do caco de vidro moído em moinho de facas

Tabela 4.2: Tamanhos médios das partículas do vidro em pó, obtidos com o equipamento Coulter LS 100Q, após moinho de bolas

Tabela 4.3: Teor de carga das formulações utilizadas neste estudo

Tabela 4.4: Determinação do alongamento na ruptura (\%) para o polímero puro e os compósitos

Tabela 4.5: Determinação da resistência à tração (MPa) para o polímero puro e os compósitos

Tabela 4.6: Determinação do módulo de elasticidade na tração (MPa) para o polímero puro e os compósitos

Tabela 4.7: Determinação da resistência ao impacto Charpy $\left(\mathrm{KJ} / \mathrm{m}^{2}\right)$ sem entalhe para o polímero puro e os compósitos

Tabela 4.8: Estabilidade dimensional média paralela ao fluxo (\%) 49

Tabela 4.9: Estabilidade dimensional média perpendicular ao fluxo (\%) 


\section{LISTA DAS FIGURAS}

Figura 2.1: Curva típica de distribuição de massa molar de uma amostra polimérica

Figura 2.2: Representação da poliamida 6 (nylon-6) e da poliamida 6.6 (nylon-

Figura 2.3: Modelo de um polímero semicristalino

Figura 2.4: Obtenção da poliamida 6 a partir do ácido $\varepsilon$ aminocapróico 9

Figura 2.5: Obtenção da poliamida 6 a partir da caprolactama

Figura 2.6: Obtenção da poliamida 6.6 10

Figura 2.7: Representação da reação de formação da poliamida 6.6 11

Figura 2.8: Estrutura da forma $\alpha$ da poliamida 6.6

Figura 2.9: Micrografia por MEV de uma amostra de talco com ampliação de 5.000 vezes

Figura 2.10: Reação de um agente de acoplagem na interface fibra de vidro polímero

Figura 2.11: Micrografia por MEV de uma superfície fraturada de poliamida 6.6 com $30 \%$ de fibra de vidro

Figura 2.12: Micrografia por MEV da fratura de um compósito de polisulfona e micro esfera de vidro

Figura 2.13: Micrografia por MEV da fratura de um compósito de poliamida 6.6 e micro esfera de vidro

Figura 2.14: Estrutura cristalina da wollastonita

Figura 2.15: Micrografia por MEV da wollastonita com ampliação de 1000 vezes

Figura 2.16: Tetraedro de $\mathrm{SiO}_{4}$

Figura 2.17: Representação bidimensional

Figura 2.18: Estrutura do vidro-sílica

Figura 2.19: Ilustração de parte de um conjunto rosca co-rotacional

Figura 3.1: Agitador eletromagnético (tipo Granutest)

Figura 3.2: Conjunto de peneiras Tyler

Figura 3.3: Corpo de prova de resistência à tração conforme norma ASTM

Figura 3.4: Exemplo das placas utilizadas para as medidas de contração 
Figura 4.1: Representação do alongamento médio na ruptura (\%).................. 43

Figura 4.2: Representação da resistência à tração média na ruptura (MPa).... 45

Figura 4.3: Representação do módulo de elasticidade médio na tração (MPa) . 46

Figura 4.4: Representação da resistência ao impacto Charpy sem entalhe $\left(\mathrm{KJ} / \mathrm{m}^{2}\right)$

Figura 4.5: Representação da estabilidade dimensional média paralela ao fluxo $(\%)$

Figura 4.6: Representação da estabilidade dimensional média perpendicular ao fluxo (\%)

Figura 4.7: Micrografia por MEV da fratura do compósito de poliamida $6.6 \mathrm{com}$ $15 \%$ de talco

Figura 4.8: Micrografia por MEV da fratura do compósito de poliamida $6.6 \mathrm{com}$

$15 \%$ de fibra de vidro

Figura 4.9: Micrografia por MEV da fratura do compósito de poliamida $6.6 \mathrm{com}$ $15 \%$ de micro esfera de vidro

Figura 4.10: Micrografia por MEV da fratura do compósito de poliamida $6.6 \mathrm{com}$ $15 \%$ de wollastonita

Figura 4.11: Micrografia por MEV da fratura do compósito de poliamida $6.6 \mathrm{com}$ 15\% de vidro moído 


\section{INTRODUÇÃO}

Os polímeros que ocorrem naturalmente - aqueles derivados de plantas e animais - têm sido usados durante muitos séculos; estes materiais incluem madeira, borracha, algodão, lã, couro e seda. Outros polímeros naturais tais como proteínas, enzimas, amidos e celulose são importantes em processos biológicos e fisiológicos em plantas e animais. No início do século XIX, ferramentas científicas tornaram possível a determinação de estruturas moleculares deste grupo de materiais e o desenvolvimento de numerosos polímeros que são sintetizados a partir de pequenas moléculas orgânicas. Desde o fim da Segunda Guerra Mundial, o campo de materiais tem sido virtualmente revolucionado pelo advento de polímeros sintéticos. Os sintéticos podem ser produzidos economicamente e suas propriedades podem ser administradas a um grau tal que muitos são superiores às suas contrapartidas naturais. Em algumas aplicações partes de metal e de madeira foram substituídas por plásticos, que têm propriedades satisfatórias e podem ser produzidos a um custo mais baixo [1].

Sistemas poliméricos são amplamente utilizados devido a algumas características particulares: facilidade de produção, baixo peso e freqüentemente natureza dúctil. Entretanto, os polímeros apresentam baixa resistência à tração e módulo de elasticidade quando comparados aos materiais cerâmicos e metálicos. Um modo de aumentar essas propriedades é a utilização de materiais de reforço, tais como fibras, esferas ou partículas originando os materiais compósitos poliméricos [2].

Materiais compósitos são materiais projetados de modo a conjugar características desejáveis de dois ou mais materiais. A grande expansão no desenvolvimento e no uso dos materiais compósitos se iniciou na década de 1970 [3].

Compósitos poliméricos (também denominados plásticos reforçados) são materiais formados por uma matriz polimérica e um reforço (fase descontínua, freqüentemente uma fibra). Entre as vantagens dos compósitos poliméricos estão: baixo peso, resistência à corrosão e a temperaturas 
elevadas e ótimas propriedades mecânicas, quando comparados aos materiais convencionais de engenharia [4].

O vidro é um ótimo agente de reforço porque tem uma alta resistência à tração e um alto módulo de elasticidade. As fibras de vidro têm uma boa estabilidade dimensional, não sofrem fluência e essas características são repassadas para o compósito reforçado com essas fibras, enquanto a matriz polimérica é responsável pela flexibilidade [3,5].

As composições individuais dos vidros variam muito, pois pequenas alterações são feitas para proporcionar propriedades específicas, tais como cor e transparência, por exemplo. Apesar de apresentar o aspecto de um sólido amorfo (sem estrutura cristalina), o vidro apresenta características de um líquido em sua ordenação atômica, mesmo em temperatura ambiente e é uma substância de alta viscosidade [6]. O vidro comum se obtém por fusão em torno de $1.550{ }^{\circ} \mathrm{C}$ da sílica, $\left(\mathrm{SiO}_{2}\right)$, carbonato de sódio $\left(\mathrm{Na}_{2} \mathrm{CO}_{3}\right)$ e carbonato de cálcio $\left(\mathrm{CaCO}_{3}\right)$, entre outras matérias-primas [7]. Sua manipulação só é possível enquanto fluído, pois se torna quente e maleável.

É importante ressaltar que o montante de vidro descartado (garrafas, vasilhames diversos, vidros planos da construção civil, etc.) representava em 2006, em nível mundial aproximadamente 7,5\% em peso do total de lixo doméstico gerado [8]. No Brasil, jogam-se no lixo cerca de 40 bilhões de garrafas e objetos de vidro por ano. O lixo de vidro deve ser separado e direcionado às usinas de reciclagem [9].

As poliamidas ou nylons são plásticos semicristalinos e pertencem a uma classe de polímeros atraente para aplicações em engenharia devido à combinação de propriedades como: estabilidade dimensional, boa resistência ao impacto sem entalhe, excelente resistência química e fácil processamento [19].

Por outro lado, as poliamidas são altamente higroscópicas e sensíveis ao entalhe, isto é, são dúcteis quando não entalhados, mas fraturam de maneira frágil quando entalhados, devido a sua baixa resistência à propagação da trinca [41].

Além disso, a adição de reforços inorgânicos confere ao compósito obtido aumento da propriedade de resistência ao impacto, módulo de 
elasticidade e boa estabilidade dimensional devido à redução da absorção de água.

A proposta deste estudo é investigar a utilização de pó de vidro como reforço da poliamida 6.6 de forma a obter um compósito que possa ser processado industrialmente e apresente propriedades mecânicas satisfatórias para a indústria de transformação.

\section{Objetivos}

> Fabricar compósitos de poliamida 6.6 e vidro reciclado (caco) sem tratamento químico utilizando técnicas de processamento convencionais;

Estudar o processamento e propriedades do compósito obtido;

Comparar as propriedades de compósitos obtidos com vidro reciclado e com as cargas convencionais, após o processo de mistura e injeção; 


\section{REVISÃO DA LITERATURA}

Neste capítulo será apresentada uma breve abordagem sobre os conceitos necessários para a elaboração e preparação do compósito de poliamida 6.6 com vidro moído reciclado. A seqüência adotada foi: polímeros, poliamidas, poliamida 6.6, compósitos, compósitos poliméricos, cargas e vidro.

\section{$2.1 \quad$ Polímeros}

De acordo com alguns autores, macromolécula é um termo geral que enquadra todas as moléculas de tamanho elevado e polímero é o termo específico utilizado para aquelas moléculas grandes que são formadas por repetições de estruturas pequenas (poli = muitos e meros = repetição) [10].

Outros autores, entretanto, afirmam que os polímeros orgânicos são geralmente constituídos de macromoléculas, ou seja, a união de átomos de massa elevada, ligados entre si por ligações covalentes e as macromoléculas, por sua vez, se associam por ligações secundárias muito mais fracas. A estrutura molecular é a principal determinante das propriedades tecnológicas dos polímeros [11].

Os polímeros são quase que totalmente originários da indústria petroquímica e apesar da crise do petróleo em 1973, observou-se neste período o desenvolvimento deste material, com uma utilização cada vez maior nas áreas de aeronáutica, automobilística, eletrônica e eletrotécnica.

Este desenvolvimento industrial impulsionou a produção dos polímeros técnicos, ou polímeros de engenharia, ou ainda, plásticos de engenharia como: policarbonatos, poliamidas, poliésteres, poliétersulfonas, poliimidas, etc. e também dos polímeros de uso corrente como: polietileno, polipropileno, PVC, ABS, etc. [11].

Os polímeros foram originalmente classificados por Carothers (1929) em polímeros de adição e polímeros de condensação com base na diferença de composição entre o polímero e os monômeros de onde 
foi sintetizado. De acordo com ele, polímeros de condensação eram aqueles polímeros formados por monômeros polifuncionais através de várias reações de condensação com a eliminação de moléculas pequenas tal como a água. Um exemplo deste tipo de reação é a obtenção das poliamidas formada a partir de diaminas e diácidos com a eliminação de uma molécula de água $[14,73]$. Já os polímeros de adição são aqueles formados a partir de monômeros sem a perda de moléculas pequenas. Diferentemente dos polímeros de condensação a unidade de repetição de um polímero de adição tem a mesma composição do monômero. A maior parte dos polímeros de adição é formada pela polimerização de monômeros que contém uma dupla ligação carbonocarbono (monômeros vinílicos) [73].

Por outro lado, Flory (1953) reforça a importância significativa da diferença no mecanismo pelo qual as moléculas do polímero são formadas. Apesar de continuar usando os termos adição e condensação em suas discussões sobre mecanismos de polimerização, a terminologia mais recente utiliza a classificação de polimerização em cadeia e em etapas [73].

Durante o processo de polimerização são formadas cadeias longas, mas de tamanhos diferentes, esse tamanho pode variar apresentando uma distribuição de peso molecular típica para cada processo, uma vez que nem todos os polímeros crescem do mesmo modo. Esse fenômeno é conhecido como polidispersão. As propriedades únicas dos polímeros são resultado, em primeiro lugar, do alto peso molecular que possuem. Flexibilidade molecular, ligações de hidrogênio, cristalinidade, ligações cruzadas etc. têm participação complementar nessas propriedades. O termo mais usado é o de peso molecular [3, 10, 11,16], mas trata-se na verdade de massas molares, e, portanto será esta a nomenclatura que será adotada neste trabalho.

Existem várias formas de determinar a massa molar média de um polímero [16].

Uma curva típica (Figura 2.1) é formada pela seguinte distribuição de massas molares [16]: 
> Massa Molar Numérica Média $\left(M_{n}\right)$ : que é sensível à concentração das espécies de baixa massa molar;

> Massa Molecular Ponderal Média $\left(M_{w}\right)$ : que é sensível às moléculas de maior massa molar;

> Massa Molecular Viscosimétrica Média $\left(M_{v}\right)$ : é uma medida de viscosidade de soluções poliméricas diluídas que permite o cálculo de uma massa molar média. Esta medida produz um valor de massa molar que está mais próximo de $M_{w}$ do que do $M_{n}$ para um polímero polidisperso.

A distribuição de massa molar, ou polidispersão é determinada a partir da razão $M_{w} / M_{n}$. Para amostras monodispersas esta razão é igual a uma unidade.

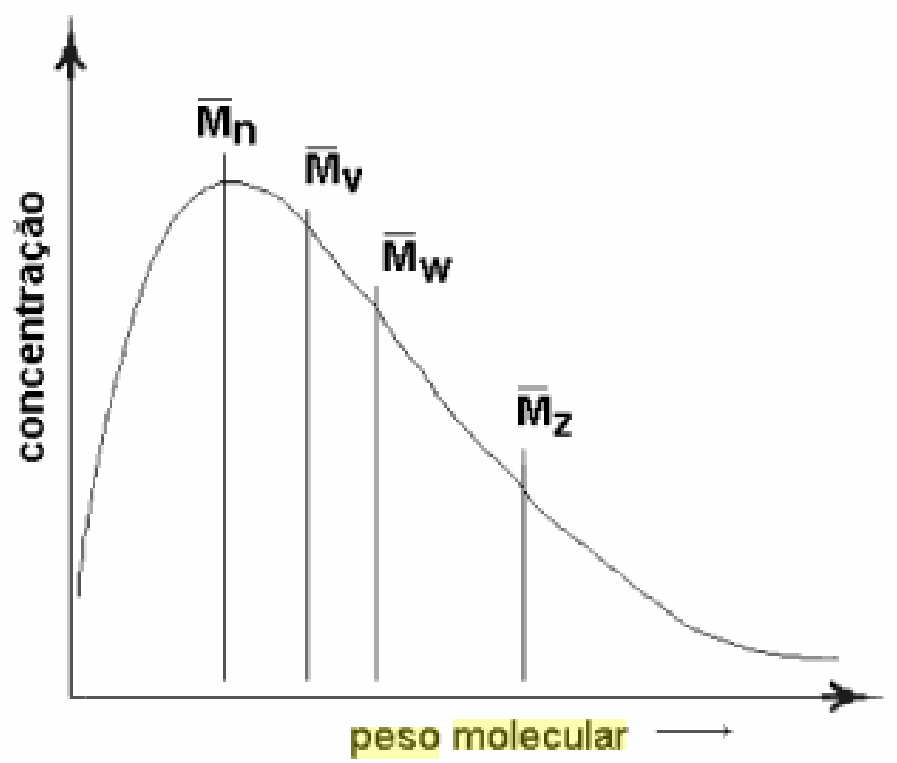

Figura 2.1: Curva típica de distribuição de massa molar de uma amostra polimérica [10].

\subsubsection{Poliamida}

De acordo com vários autores [17, 18,19], as poliamidas constituem uma classe de polímeros bastante atraentes para aplicações de engenharia devido à combinação de propriedades boa resistência química e a abrasão, elevada resistência à tensão e à flexão, estabilidade dimensional e fácil processamento. Por outro lado, as poliamidas são bastante sensíveis ao entalhe, por apresentarem alta resistência à iniciação de trinca, ou seja, são dúcteis quando não 
entalhados, mas fraturam de maneira frágil quando entalhados [18]. Além disso, devido ao seu caráter hidrofílico, propriedades como estabilidade dimensional, densidade, resistência mecânica, elétrica variam de acordo com a umidade [17, 20,21].

A primeira poliamida sintética foi comercializada em 1935 pela empresa DuPont e batizada com o nome de Nylon [27]. Ela se apresentava sob a forma de fibras e foi utilizada para a fabricação de meias.

As poliamidas consistem de segmentos de polietileno $\left(\mathrm{CH}_{2}\right)_{\mathrm{n}}$ separados por unidades de peptídeos $(\mathrm{NH}-\mathrm{CO})$ que estão tanto paralelos como antiparalelos. Estas unidades de peptídeos possibilitam a ligação do hidrogênio com a cadeia do polímero (Figura 2.2), proporcionando ao Nylon algumas propriedades típicas [22].

nylon-n: -[-( $\left.\mathrm{NH}-\mathrm{CO})-\left(-\mathrm{CH}_{2}\right)_{\mathrm{n}-1-1}\right]-(1)$

nylon-m,n:-[-(NH-CO)-($\left.\left(\mathrm{CH}_{2}\right)_{\mathrm{n}-2}-(\mathrm{CO}-\mathrm{NH})-\left(\mathrm{CH}_{2}\right)_{\mathrm{m}}-\right]-(2)$

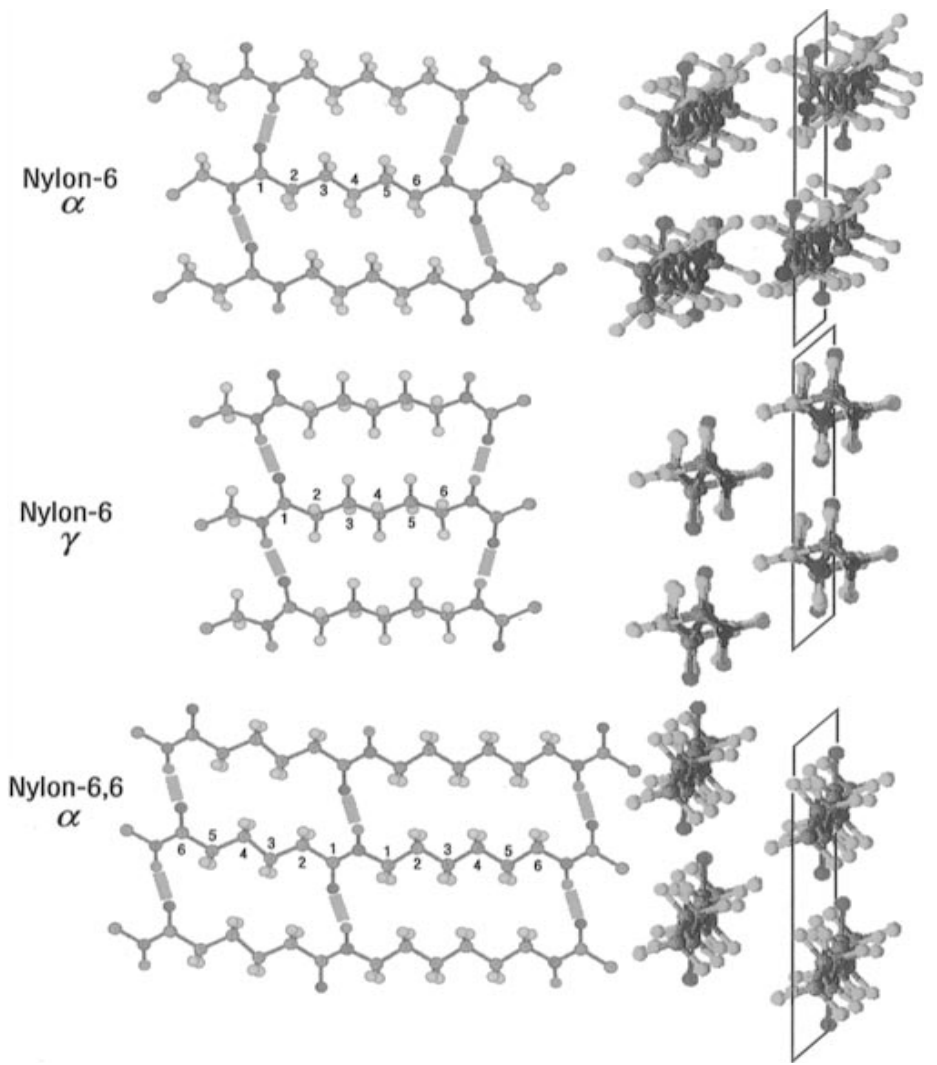

Figura 2.2: Representação da poliamida 6 (nylon-6) e da poliamida 6.6 (nylon-6.6) [22]. 
Em contraste com polímeros altamente cristalinos como o polietileno, as poliamidas, que são semicristalinas, podem ter seu grau de cristalinidade controlado em larga escala [22,23].

A alteração da densidade da amida pode implicar na mudança de propriedades como a temperatura de fusão, módulo, resistência ao impacto à baixa temperatura, absorção da umidade, e resistência química a sais e ácidos.

A Figura 2.3 apresenta o modelo de um polímero semicristalino.

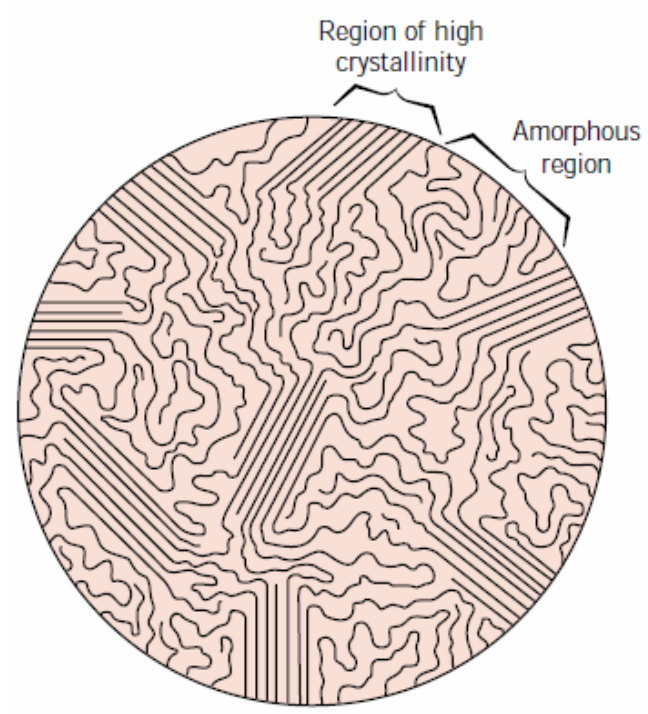

Figura 2.3: Modelo de um polímero semicristalino [1].

Existem diferentes tipos de poliamidas, porém as mais representativas deste grupo são a poliamida 6 e a poliamida $6.6[22,24]$, apresentam estrutura linear e conformação das cadeias em zigue-zague com pontes de hidrogênio entre grupos funcionais [25]. São amplamente utilizadas na produção de carpetes e peças de vestuário. Apresentam também custo relativamente competitivo em virtude da grande capacidade de produção mundial de seus monômeros [26].

A poliamida 6 foi produzida originalmente a partir do aquecimento do ácido $\varepsilon$-aminocapróico e a eliminação da água entre as moléculas de natureza idênticas formava as cadeias de poliamida [13] (Figura 2.4). 


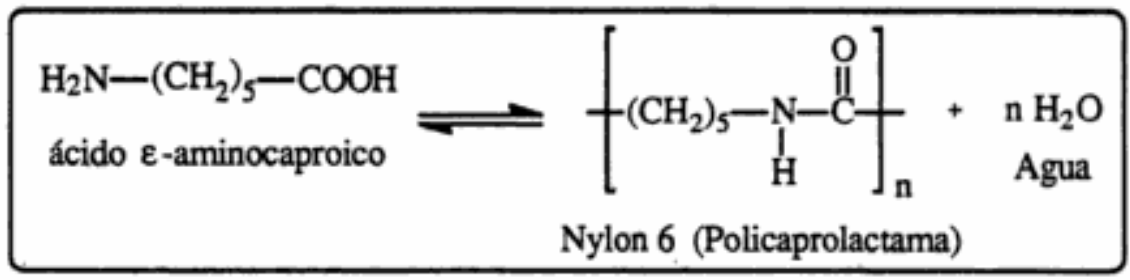

Figura 2.4: Obtenção da poliamida 6 a partir do ácido $\varepsilon$ - aminocapróico [15]

Descobriu-se mais tarde que era possível a obtenção do mesmo produto pela abertura do anel e polimerização da caprolactama, uma amida interna (Figura 2.5).

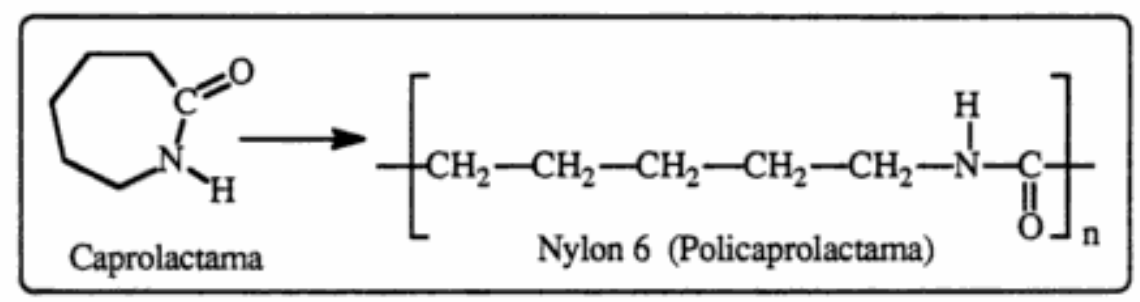

Figura 2.5: Obtenção da poliamida 6 a partir da caprolactama [15].

A poliamida 6.6, outra componente importante do grupo das poliamidas e que é um dos objetos deste estudo, será discutida a seguir.

\subsubsection{Poliamida 6.6}

O desenvolvimento da poliamida 6.6., tem sua origem no ano de 1927, com a implantação pela empresa norte americana, E. I. DuPont de Nemours de um programa de pesquisa em química orgânica para 0 desenvolvimento de processos e produtos químicos. Em 1928 o Dr. Wallace Hume Carothers, da Universidade de Harvard, assume a direção das pesquisas, sendo que em 1929, o objetivo dos trabalhos direcionava-se na obtenção de novas fibras para aplicação têxtil e no desenvolvimento de polímeros por policondensação.

O primeiro processo de síntese de um polímero a partir da hexametilenodiamina e do ácido adípico foi realizado em laboratório, em 28 de fevereiro de 1935 e denominado inicialmente de polímero 6.6.

Em 1938 foram iniciados os testes para produção industrial em uma unidade da DuPont em Seaford, Delaware e em 1940 o fio denominado de 
nylon, foi lançado comercialmente na produção de meias femininas. A Figura 2.6 apresenta o fluxo do processo de obtenção da poliamida 6.6 a partir do benzeno [27].

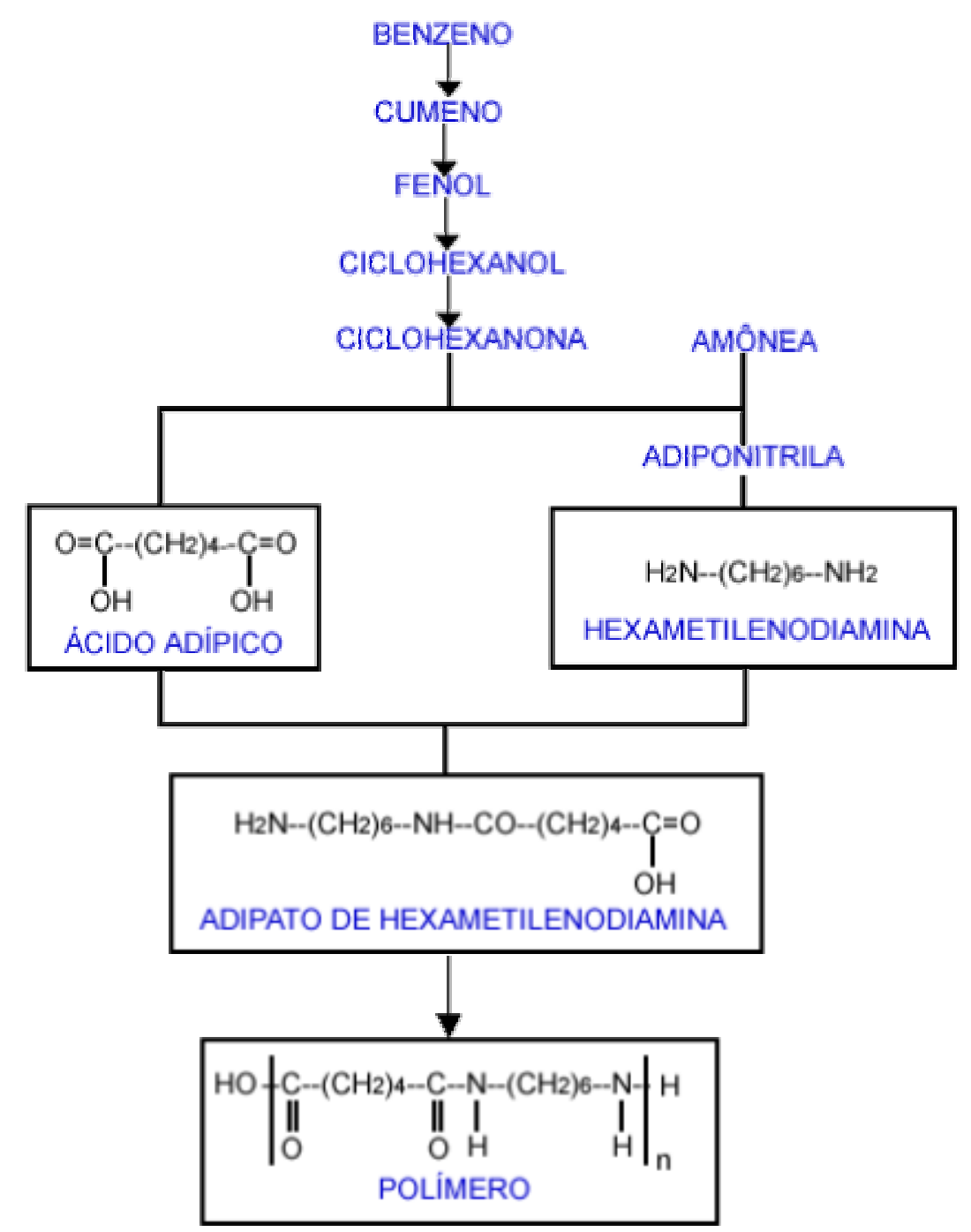

Figura 2.6: Obtenção da poliamida 6.6

Conforme já mencionado, a poliamida 6.6 é obtida a partir de um ácido dicarboxílico, o ácido hexanodióico (ácido adípico) que possui seis átomos de carbono, e uma diamina o hexano-1,6-diamina (hexametileno diamina) que também possui seis átomos de carbono (Figura 2.7). O aquecimento da mistura dos dois compostos leva a eliminação de uma molécula de água entre um grupo amina e um grupo carboxílico e a formação de uma amida. A reação se repete um grande número de vezes formando um polímero de cadeia longa que pode ser utilizado em inúmeros processos de fabricação. Pode-se fiá-la para a 
obtenção de fibras que serão empregadas na produção de carpetes, ou ainda moldá-la para a obtenção de peças rígidas que serão utilizadas como engrenagens diversas ou ainda em peças para a indústria automobilística [13].

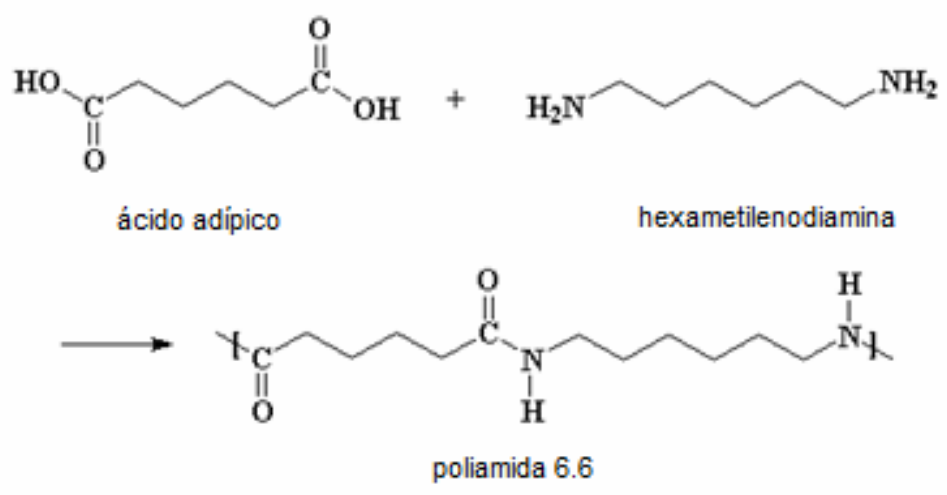

Figura 2.7: Representação da reação de formação da poliamida 6.6 [28].

Para a produção da poliamida 6.6 não é necessário o uso de catalisadores, pois o ácido (monômero) age como catalisador [28].

Relata-se que existem fortes interações entre moléculas que contém ligações que apresentam um momento dipolar permanente, normalmente associadas à presença de grupos $\mathrm{Cl}, \mathrm{CN}$ ou $\mathrm{OH}$. Estas ligações são um fator importante na cristalização das poliamidas, sendo que na poliamida 6.6 as pontes de hidrogênio intermoleculares se estabelecem entre os grupos amida e os grupos $\mathrm{OH}$ (Figura 2.8).
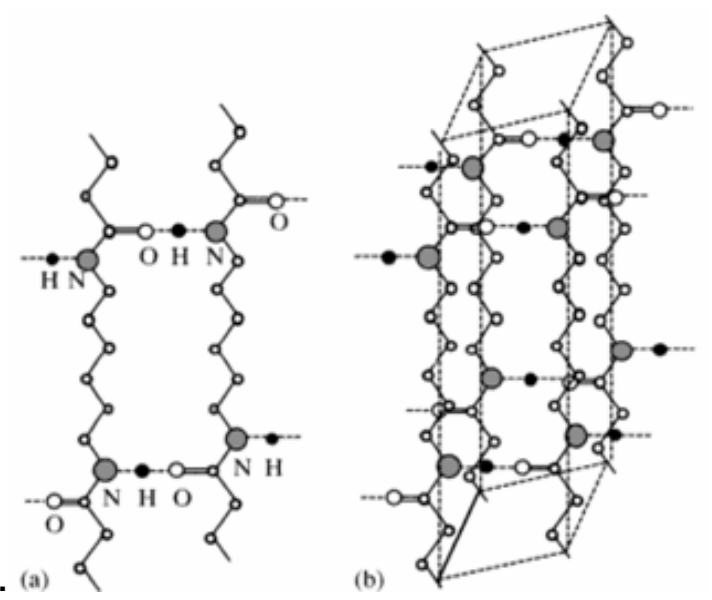

Figura 2.8: Estrutura da forma $\alpha$ da poliamida 6.6: (a) camada contendo as pontes de hidrogênio e (b) malha elementar (os hidrogênios que não formam pontes são omitidos) [29]

A poliamida 6.6 possui limitações de estabilidade dimensional 
durante o processo de resfriamento de peças moldadas por injeção. Este efeito pode ser corrigido com a adição de cargas à base de silicatos, como o talco [34].

\subsection{Cargas e Reforços}

Chama-se de carga ou reforço todo componente insolúvel que quando é adicionado ao polímero modifica uma ou mais propriedades do polímero puro. Estes reforços são freqüentemente classificados segundo sua forma: grãos ou esferas, lamelas, agulhas ou fibras (Tabela 2.1) [30].

Tabela 2.1: Classificação das cargas ou reforços [30].

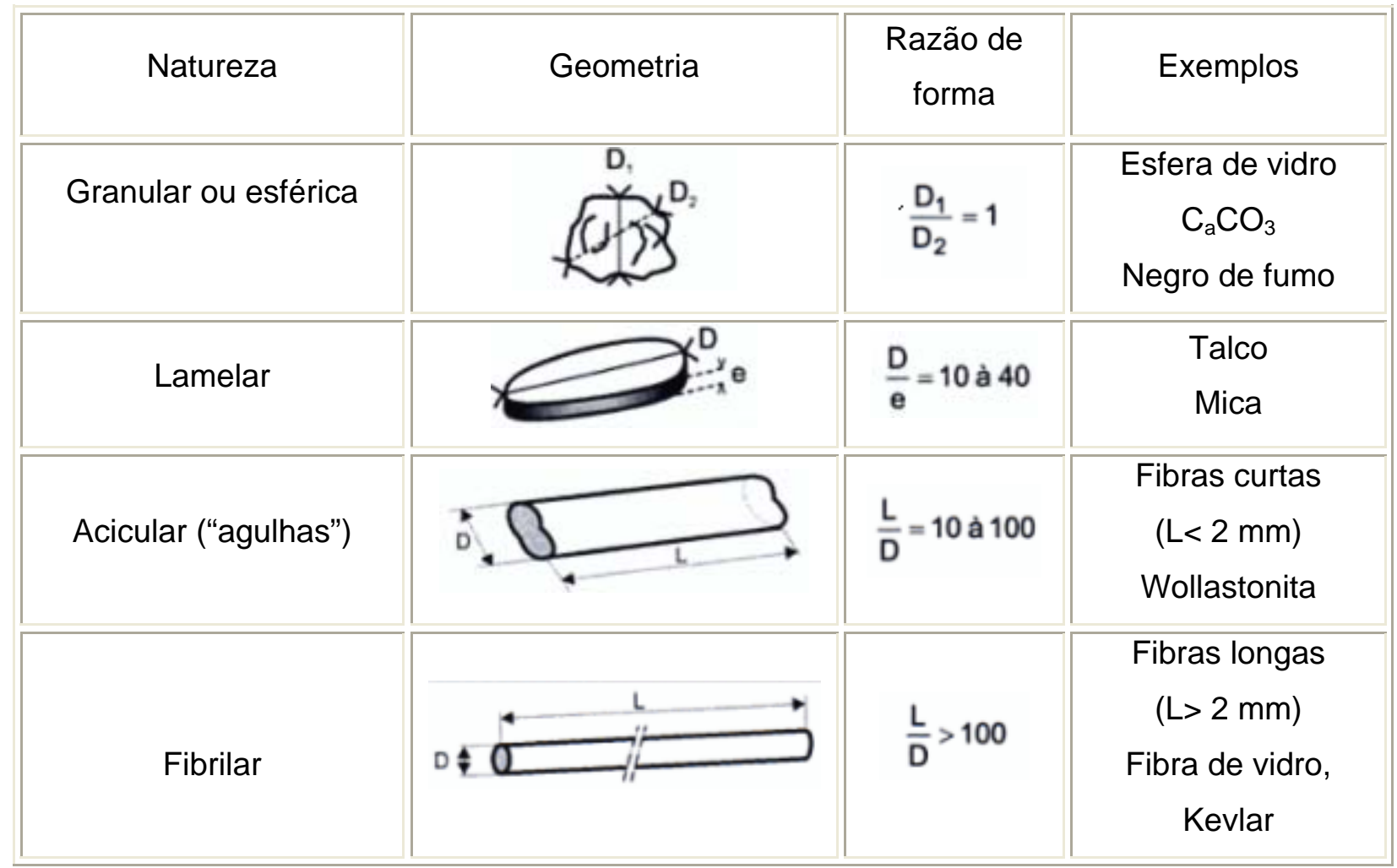

As funções básicas das cargas minerais ou sintéticas em compostos termoplásticos são estratégicas e econômicas, substituindo parcialmente as matrizes poliméricas, ampliando suas aplicações com a incorporação ou promoção de propriedades físicas, químicas e de processamento desejáveis no plástico [12,31].

Uma das primeiras etapas de um projeto de desenvolvimento de um novo compósito polimérico é a escolha dos tipos de cargas a 
serem testadas, ou suas combinações, que misturadas ao polímero e demais aditivos, assegurem as especificações técnicas propostas a um custo desejado. Esta escolha não pode ser arbitrária, ela deve ser baseada em critérios técnicos e econômicos previamente estabelecidos, a partir de um profundo conhecimento das propriedades de cada componente [31].

As cargas são aditivos sólidos, geralmente inorgânicos, que são incorporados em uma matriz polimérica e podem ser classificados de acordo com o efeito com o seu efeito nas propriedades mecânicas da mistura resultante. Além de proporcionar redução de custo estas cargas podem proporcionar o aumento da densidade do composto, reduzir a estabilidade dimensional, além de aumentar a dureza e a temperatura de deflexão sob carga. Em alguns casos, forma-se uma ligação química entre a carga e o polímero e em outros casos o volume ocupado pela carga afeta as propriedades do termoplástico [12].

Dentre as cargas disponíveis, utilizamos neste trabalho, para efeito de comparação com o caco de vidro, aquelas que são mais utilizadas industrialmente: talco, wollastonita, micro esfera de vidro e fibra de vidro e serão descritas a seguir.

\subsubsection{Talco}

O talco é uma matéria prima mineral amplamente utilizada na indústria moderna podendo ser empregado em vários segmentos [32].

Dentre estes segmentos pode-se destacar o de compósitos termoplásticos, inclusive o de engenharia sendo que neste caso ele é utilizado como carga mineral, para redução da quantidade de matriz polimérica em até 40\%, ou como mineral funcional, para a promoção de propriedades físicas, químicas e de processamento, propriedades estas desejáveis no plástico. Sua estrutura cristalina, a textura lamelar e o comportamento reológico explicam as propriedades mais notáveis dos compósitos termoplásticos carregados com talco: rigidez e estabilidade térmica e dimensional, entre outras. Este mineral pode ocorrer em uma variedade de ambientes geológicos, associado a inúmeras impurezas minerais [31]. 
A composição química do talco, expressa pela fórmula de óxidos, é $3 \mathrm{MgO} 4 \mathrm{SiO}_{2} \cdot \mathrm{H}_{2} \mathrm{O}$. A fórmula da célula unitária, que é o dobro da fórmula de óxidos, é $\mathrm{Mg}_{6} \mathrm{Si}_{8} \mathrm{O}_{20}(\mathrm{OH})_{4}$. Os cristais de talco são formados pelo empilhamento de camadas 2:1, cada uma sendo constituída por uma folha octaédrica de brucita $\left[\mathrm{Mg}(\mathrm{OH})_{2}\right]$ no meio de duas folhas tetraédricas de $\mathrm{SiO}_{2}$. A carga elétrica da célula unitária é neutra. Os cristais de talco clivam facilmente, gerando cristais menores, de forma lamelar e com perfil ou contorno irregular. Desse comportamento decorrem as propriedades lubrificantes do talco em pó [74].

A Figura 2.9 apresenta uma micrografia de uma amostra de talco [35].

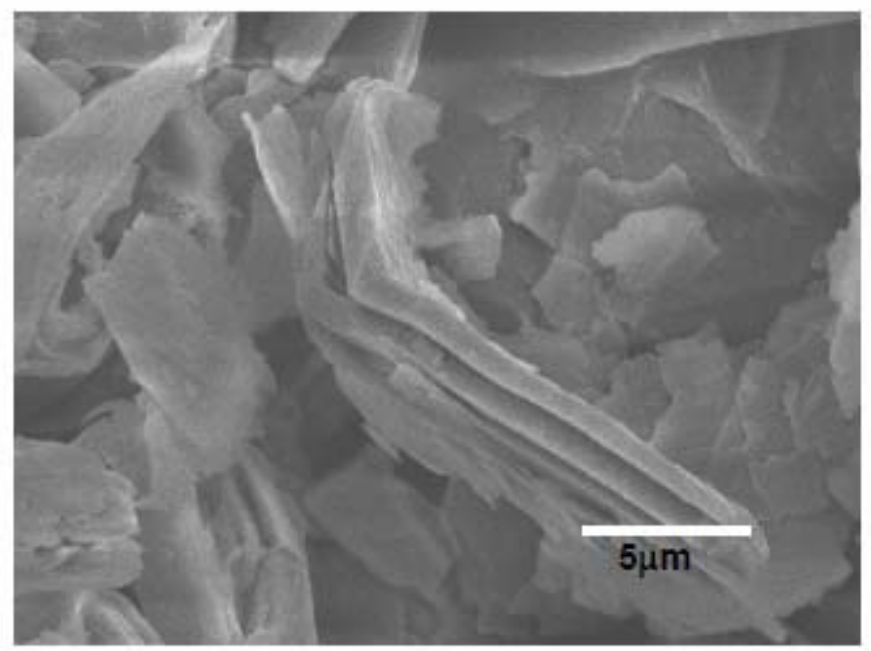

Figura 2.9: Micrografia pó MEV de uma amostra de talco com ampliação de 5.000 vezes [35]

\subsubsection{Fibra de Vidro}

Apesar das fibras serem comuns há 3000 anos, suas propriedades como reforços só foram conhecidas durante este século [36].

A fibra de vidro é atualmente o agente de reforço mais utilizado em virtude de suas características mecânicas e custo acessível [37]. A grande maioria ( $95 \%)$ é de borosilicato de alumínio contendo pequenas quantidades $(\sim 1 \%)$ de fundentes $\left(\mathrm{Na}_{2} \mathrm{O}+\mathrm{K}_{2} \mathrm{O}\right)$ e são conhecidas como fibras de vidro tipo E. Esses fundentes reduzem a viscosidade do vidro permitindo a obtenção das fibras em temperatura mais baixa.

As fibras de vidro tipo E são fiadas a uma temperatura de $1250^{\circ} \mathrm{C}$ a 
elevadas velocidades (várias dezenas de metros por segundo) resfriadas a ar e em seguida em água [38]. Após receber a ensimagem, os filamentos que possuem diâmetro entre 5 a $25 \mu \mathrm{m}$ são unidos para formar o fio de base. Esta ensimagem é responsável pela adesão química da fibra de vidro na matriz polimérica e sua composição varia de acordo com o tipo de polímero presente na matriz [7]. Os agentes de acoplagem mais utilizados são os silanos e o mecanismo está representado na Figura 2.10.

(a)

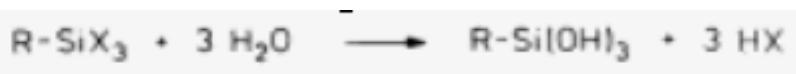

(b)

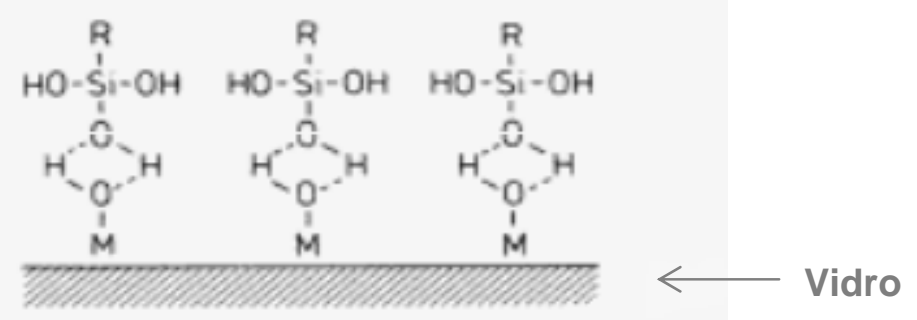

(c)
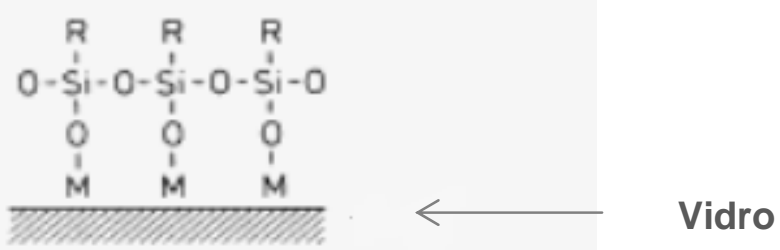

(d)
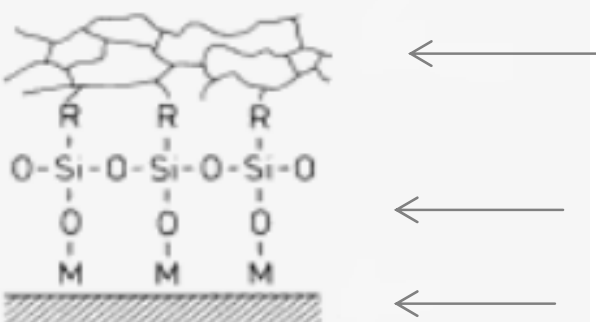

Polímero

Agente de Acoplagem

Vidro

Figura 2.10: Reação de um agente de acoplagem na interface fibra de vidro polímero: (a) hidrólise do agente de acoplagem com a formação de silanóis; (b) formação da ligação do hidrogênio entre o silanol e a superfície do vidro; (c) formação de um a ligação química na superfície do vidro e (d) com o polímero, onde $\mathrm{Cl}$ representa um halogênio e $\mathrm{M}$ um cátion metálico [7].

Ao longo das últimas décadas, compósitos de matriz polimérica reforçados com fibra de vidro foram bem aceitos como materiais de engenharia para aplicações automobilísticas, indústrias aeroespacial e naval, em ambientes corrosivos, necessidade de alta resistência mecânica (módulo) e em aplicações em temperaturas abaixo de $0^{\circ} \mathrm{C}[39,43]$. Porém quando 
processadas, as fibras se tornam mais curtas especialmente no caso de moldagem por injeção na qual uma grande tensão é aplicada para fundir [40].

A Figura 2.11 apresenta uma micrografia de um compósito de poliamida 6.6 com $30 \%$ de fibra de vidro [41].

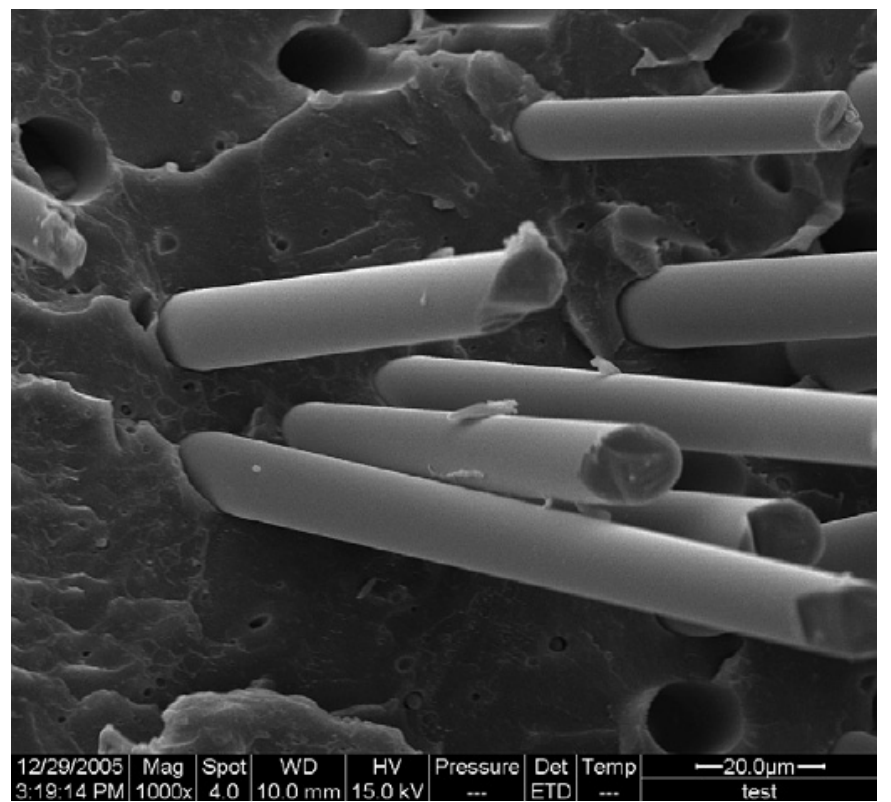

Figura 2.11: Micrografia por MEV de uma superfície fraturada de poliamida 6.6 com $30 \%$ de fibra de vidro. [41].

\subsubsection{Micro Esfera de Vidro}

A micro esfera de vidro vem sendo largamente utilizada para melhorar propriedades mecânicas e térmicas de polímeros comerciais [23]. Apresenta várias diferenças em relação a outras cargas não esféricas, tais como fibras, grânulos, flocos e irregulares, como, por exemplo, a razão entre a área e o volume é a menor dentre todas as mencionadas o que resulta em uma viscosidade menor quando comparada à adição do mesmo volume de outra carga [30, 43].

As Figuras 2.12 [43] e 2.13 [72] apresentam micrografias obtidas com auxílio de um MEV, para uma amostra de micro esfera de vidro em polisulfona e para outra em poliamida 6.6. 


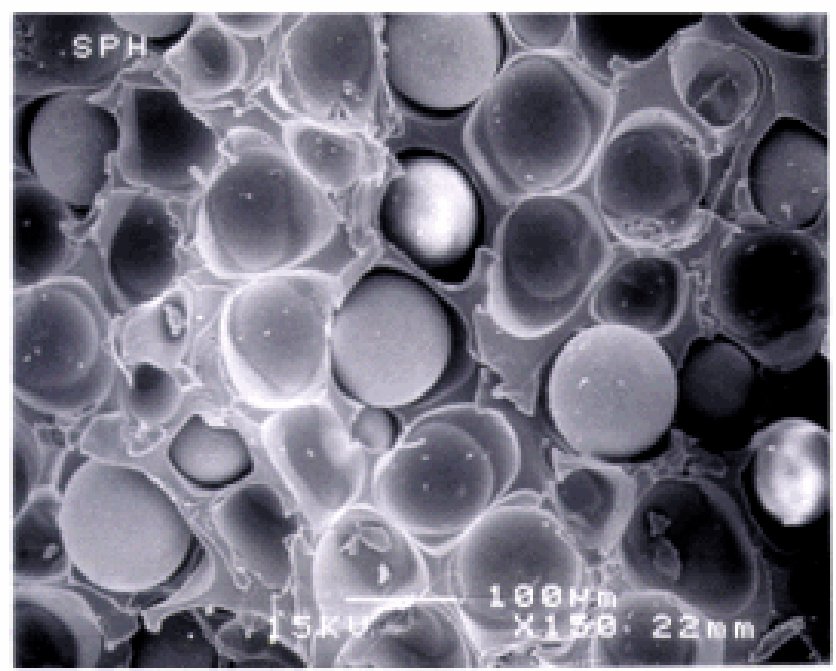

Figura 2.12: Micrografia por MEV da fratura de um compósito de polisulfona e micro esfera de vidro [43].

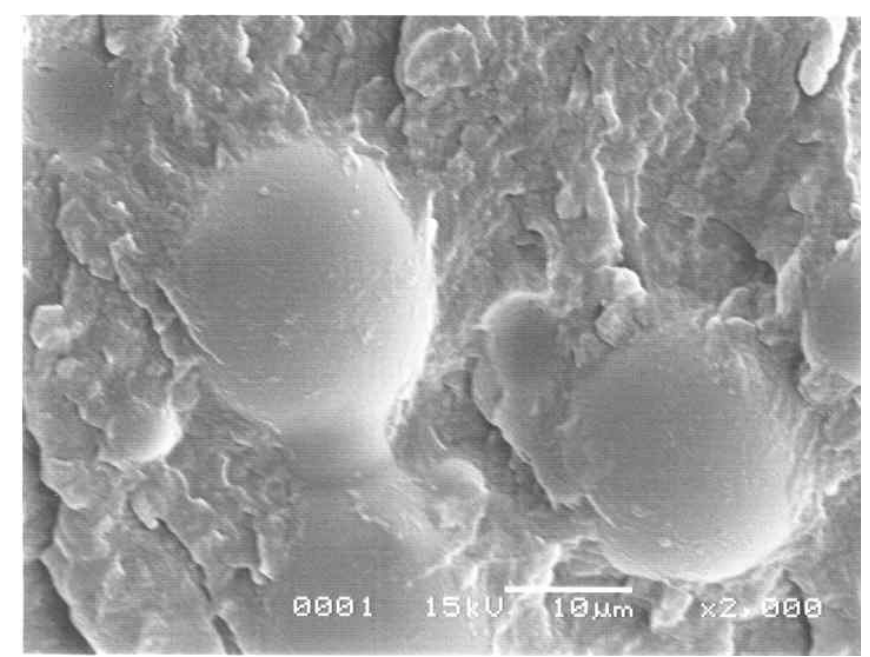

Figura 2.13: Micrografia por MEV da fratura de um compósito de poliamida 6.6 e micro esfera de vidro [72].

Os múltiplos benefícios para o processo e qualidade das peças acabadas podem ser resumidos, como se apresenta a seguir [44]:

\section{Melhor dispersão:}

- Melhora a distribuição das fibras nas resinas;

- $\quad$ Permite produzir peças mais complexas - peças de alta qualidade;

- $\quad$ Possibilita qualidade uniforme de produção, havendo menos rejeição. 


\section{$>\quad$ Maior fluidez (Efeito Rolamento)}

- Menor viscosidade do sistema de resinas;

- Melhor enchimento dos moldes;

- $\quad$ Aumento de produção.

\section{$>\quad$ Forma esférica}

- $\quad$ Comportamento isotrópico;

- $\quad$ Contrações uniformes em todas as direções;

- Menos deformações, ocorrendo maior estabilidade dimensional.

\subsubsection{Wollastonita}

A wollastonita, nomeada devido a W.H. Wollaston, um mineralogista e químico inglês, é um metasilicato de cálcio com formula química $\mathrm{CaSiO}_{3}$. É o único mineral natural acicular, não metálico. Esta acicularidade é a principal razão de sua ascendência no final da década de 70 e 80 , como substituto do amianto e fibra de vidro. Sua composição teórica é de $48,3 \%$ de óxido de cálcio e 51,7\% de dióxido de silício, mas pode conter impurezas como Al, Fe, Mg, Mn, $\mathrm{K}$ e Na. As duas formas de formação deste mineral envolvem metamorfismo (calor e pressão) do calcário. A sílica (quartzo) e o calcário reagem para formar a wollastonita, isto ocorre normalmente através de contato metamórfico como resultado de atividade ígnea intrusiva. Pode se formar também pela passagem de soluções hidrotérmicas com alto teor de sílica através de leitos de calcário em um processo chamado metasomatismo. O mineral é usualmente branco, mas pode ser cinza, marrom ou vermelho de acordo com as impurezas.

A wollastonita sintética é preferida em função do baixo nível de impurezas e propriedades físico-químicas constantes. Ela existe em três tipos cristalinos diferentes: 1A (wollastonita, triclínica), 2M (Parawollastonita, monoclínica) e 7M (Pseudowollastonita, triclínica). O tipo 1A é a forma predominante, sendo os outros dois muito raros na natureza. A sua aplicação como carga em compósitos poliméricos é devida a baixa absorção de água, boa estabilidade térmica, pureza química e propriedades de reforço [45]. 
A Figura 2.14 apresenta a estrutura cristalina da wollastonita.

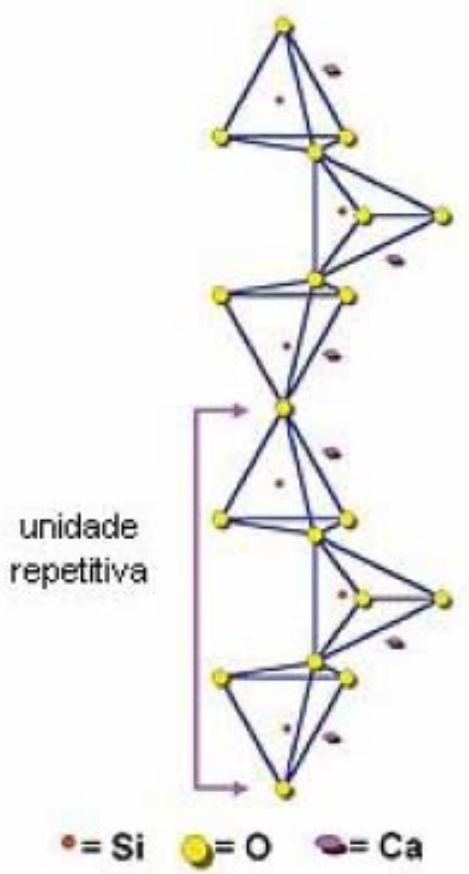

Figura 2.14: Estrutura cristalina da wollastonita [45].

A Figura 2.15 apresenta uma micrografia (MEV) da wollastonita com ampliação de 1000 vezes [62].

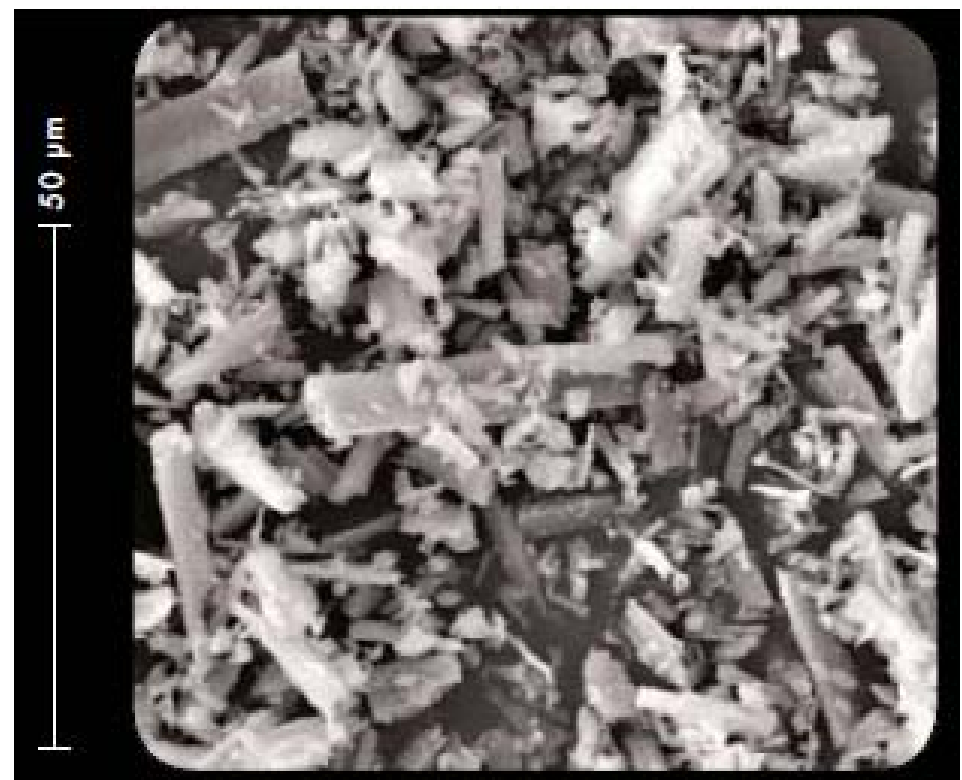

Figura 2.15: Micrografia por MEV da wollastonita - ampliação de 1000 vezes [62] 


\subsubsection{Vidro}

\subsubsection{Histórico e Definição}

O vidro é um dos materiais mais versáteis e também um dos mais antigos, pois nem sempre foram fabricados pelo homem $[46,47]$. Os chamados vidros naturais podem ser formados quando alguns tipos de rochas são fundidos a elevadas temperaturas e, em seguida, solidificadas rapidamente (erupções vulcânicas) [6].

Os primeiros vidros incolores surgiram por volta de 100 d.C., em Alexandria, graças à introdução de óxido de manganês nas composições e de melhoramentos importantes nos fornos, como a produção de altas temperaturas e o controle da atmosfera de combustão. A composição desta época era basicamente misturas de sílica, cal e soda. A adição de baixos teores de íons de cobalto, cromo, cobre, manganês e ferro promovem mudanças de cor, como por exemplo, a adição de 0,15\% de CoO confere ao vidro de carbonato de sódio a cor azul escura [3,6].

No Brasil a produção do segmento de vidros está concentrada na região Sudeste, em torno de $86,4 \%$ da capacidade instalada. Nessa indústria se destacam os segmentos de embalagens $(47,5 \%)$, vidros planos $(37,6 \%)$ e de vidros domésticos (6,6\%), que totalizam 90,7\% da produção [48].

Os primeiros estudos sobre vidro foram realizados por Michael Faraday, em 1830, que definiu o vidro como sendo "materiais mais aparentados a uma solução de diferentes substâncias do que um composto em si" [6].

O vidro inorgânico é definido como uma substância amorfa (não apresenta ordem de longo alcance), transparente ou translúcida à luz visível, com propriedades isotrópicas. É isolante térmico e elétrico, amolece antes de fundir permitindo a conformação por sopro de formas intrincadas que consiste de uma mistura óxidos sempre com o $\mathrm{SiO}_{2}$ (silicatos) como predominante, ou ainda de boratos e fosfatos, formados pela fusão de silicatos, ou óxidos de boro ou fósforo dentro de uma massa que resfria em uma condição rígida sem cristalização. Podem ser formulados para absorver ou transmitir determinados comprimentos de onda $[3,8,49,50]$.

Pode ser definido ainda como um material inerte, mas que apresenta a capacidade de estabelecer interações com diversas substâncias (água, 
aminas, ácidos carboxílicos, mercaptanas, etc.). Essas interações podem ser através de ligações de van der Waals, ligações de hidrogênio, ataque nucleófilo e eletrofílico. Assim, tratamentos químicos e a introdução de grupos funcionais são facilitados devido ao caráter reativo da estrutura vítrea, principalmente pelos grupos silanóis $(\mathrm{Si}-\mathrm{OH})$ da superfície [8].

\subsubsection{Composição e Propriedades}

O principal componente do vidro é o tetraedro de $\mathrm{SiO}_{4}$ (Figura 2.16) e os vidros tradicionais devem ser classificados como materiais cerâmicos [3, $8,79]$.
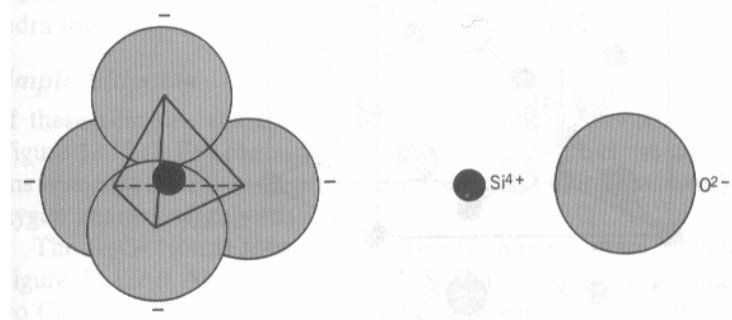

Figura 2.16 - Tetraedro de $\mathrm{SiO}_{4}[1]$

A base estrutural para a formação de vidros por fusão/resfriamento foi firmada por Zachariasen (Figura 2.17), que propôs que o arranjo atômico em vidros é caracterizado por uma rede tridimensional estendida que apresenta ausência de simetria e periodicidade e este é o fator que diferencia o vidro do cristal $[6,75]$.

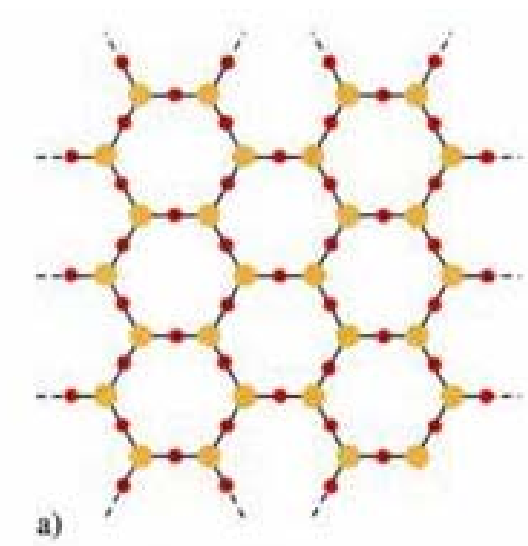

a)

t.

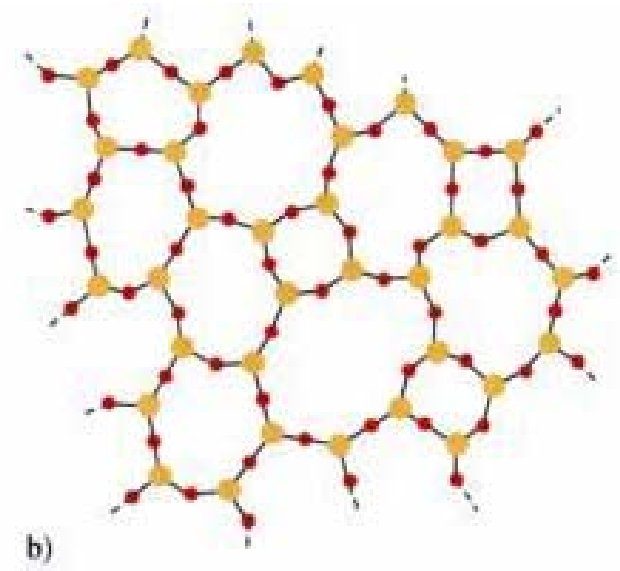

b)

a) de um cristal de quartzo; b) do vidro [75].

A Figura 2.18 apresenta esquematicamente a estrutura do vidro sílica, que é um sólido acima de $1000^{\circ} \mathrm{C}$ devido à ligação covalente entre os 
átomos de Si e O. A adição de soda $\left(\mathrm{Na}_{2} \mathrm{O}\right)$ rompe a estrutura e abaixa a temperatura de amolecimento (temperatura de trabalho) para próximo dos $600^{\circ} \mathrm{C}$. O vidro-soda resultante é utilizado na fabricação de garrafas e janelas. Com a adição de óxido de boro $\left(\mathrm{B}_{2} \mathrm{O}_{3}\right)$ obtém-se o vidro boro - silicato, sendo o pyrex um tipo, que trabalha em altas temperaturas [50].

(a)

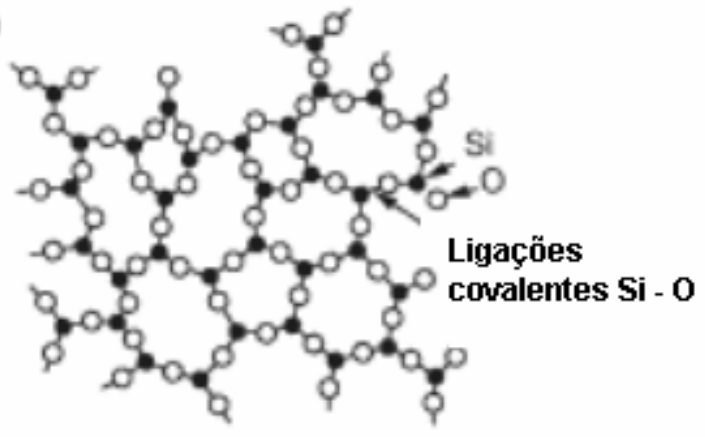

(b)

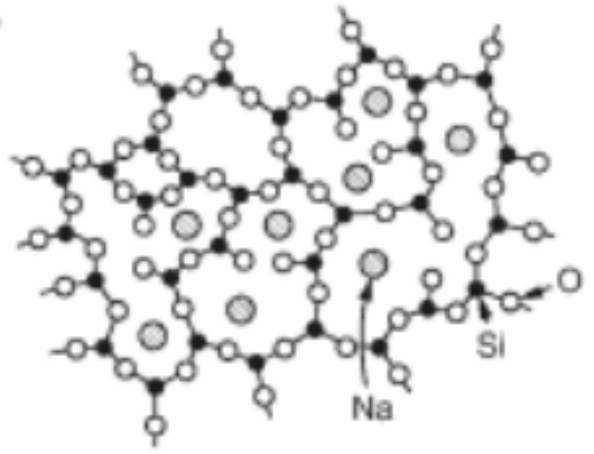

Figura 2.18: Estrutura do vidro-sílica - a) Átomo na sílica amorfa e b) Como a adição de soda rompe a ligação da sílica amorfa resultando no vidro-soda [50].

Além do óxido de sódio, pode-se introduzir óxido de cálcio e chumbo para reduzir a temperatura de fusão da sílica e a viscosidade do líquido. Além disto, os cátions $\mathrm{Na}^{+}$dificultam a cristalização e facilitam a formação de fase vítrea. Os compostos $\mathrm{SiO}_{2}, \mathrm{~B}_{2} \mathrm{O}_{3}, \mathrm{GeO}_{2}$ e $\mathrm{P}_{2} \mathrm{O}_{5}$ apresentam alta energia de ligação $(80 \mathrm{kcal} / \mathrm{mol})$ e são denominados formadores de rede. Os óxidos $\mathrm{Na}_{2} \mathrm{O}$, $\mathrm{K}_{2} \mathrm{O}, \mathrm{CaO}$ e $\mathrm{MgO}$ apresentam baixa energia de ligação ( $<40 \mathrm{kcal} / \mathrm{mol}$ ) e são denominados modificadores de rede [6]. A Tabela 2.2 apresenta as composições típicas de diversos vidros comerciais. 
Tabela 2.2: Composições típicas de diversos vidros comerciais [76]

\begin{tabular}{|c|c|c|c|c|c|c|c|c|c|c|}
\hline & & $\mathrm{SiO}_{2}$ & $\mathrm{Al}_{2} \mathrm{O}_{3}$ & $\mathrm{~B}_{2} \mathrm{O}_{3}$ & $\mathrm{Na}_{2} \mathrm{O}$ & $\mathrm{K}_{2} \mathrm{O}$ & $\mathrm{CaO}$ & $\mathrm{MgO}$ & $\mathrm{PbO}$ \\
\hline \multirow{3}{*}{ sodo-cálcicos } & & & & & & & & \\
\hline \multirow{3}{*}{ Borossilicato } & Elano & 71,0 & 1,0 & - & 13,5 & 0,5 & 10,0 & 4,0 & - \\
& Lâmpada & 73,0 & 1,0 & - & 16,5 & 0,5 & 5,0 & 4,0 & - \\
\hline \multirow{3}{*}{ Chumbo } & Pyrex & 79,0 & 2,0 & 13,0 & 5,5 & - & - & - & - \\
& Fibra isolação & 66,0 & 1,5 & 3,5 & 15,5 & 1,0 & 8,0 & 4,0 & - \\
\hline \multirow{3}{*}{ Aluminoborossilicato } & Cristal & 56,0 & - & - & 4,0 & 12,0 & 2,0 & 2,0 & 24,0 \\
& Néon & 63,0 & 1,0 & - & 8,0 & 6,0 & - & - & 22,0 \\
& Lente & 32,0 & - & - & 1,0 & 2,0 & - & - & 65,0 \\
\hline & Farmacêutico & 72,0 & 6,0 & 11,0 & 7,0 & 1,0 & 1,0 & - & - \\
& Fibra reforço & 55,0 & 15,0 & 7,0 & - & - & 19,0 & 4,0 & - \\
& Tubo & 62,0 & 17,0 & 5,0 & 1,0 & - & 8,0 & 7,0 & - \\
& combustão & & & & & & & & \\
\hline
\end{tabular}

Apesar das composições individuais variarem muito, a sílica constitui a base do vidro, é comum em todos os tipos e tem função vitrificante. A alumina $\left(\mathrm{Al}_{2} \mathrm{O}_{3}\right)$ aumenta a resistência mecânica, o MgO garante resistência ao vidro para suportar mudanças bruscas de temperatura e o $\mathrm{CaO}$ proporciona estabilidade contra ataques de agentes atmosféricos [76].

\subsubsection{Fabricação}

Na produção de vidros, as matérias primas tais como: areia especial, sulfato, calcáreo, dolomita, barrilha, feldspato e hematita são misturadas e levadas ao forno de fusão por correias transportadoras. Um forno de fusão de vidros tem várias zonas de aquecimento, na faixa de 1500 a $1200^{\circ} \mathrm{C}$. $\mathrm{Na}$ produção de vidros planos, a temperatura de saída do material do forno está entre 1100 e $1000^{\circ} \mathrm{C}$. Uma camada fluida de vidro flutua ("floating") sobre estanho líquido. A temperatura de saída da zona de "floating" situa-se por volta de $600^{\circ} \mathrm{C}[3]$. 


\subsubsection{Reciclagem do vidro}

O vidro é $100 \%$ reciclável e que pode ser reprocessado infinitas vezes. O vidro reciclado além de ser utilizado para fabricar o produto original tem outras aplicações, entre elas a fibra de vidro [51].

Mundialmente, está aumentando o uso de vidro reciclado em substituição à matéria prima mineral virgem nos diversos tipos de vidro, exceto nos vidros planos [48].

Através do processo de moagem o vidro é triturado e se obtém o vidro particulado que pode ser diretamente reaproveitado pela indústria vidreira. No entanto se produz também o vidro particulado mais fino, com granulometria abaixo de $150 \mu \mathrm{m}$, que é indesejável neste tipo de indústria, uma vez que nos grandes fornos de fusão de vidro o uso desse material é evitado de modo a impedir o fenômeno de arraste de pó pela chaminé, além da possível deposição acelerada do vidro fundido nas paredes internas do forno, o que acarreta corrosão e o conseqüente desgaste precoce dos refratários do forno $[52,53]$.

\subsubsection{Materiais Compósitos}

Os materiais compósitos podem ser definidos como misturas (ao nível macroscópico) não solúveis de dois ou mais constituintes com distintas composições, estruturas e propriedades que se combinam e que têm funções distintas, sendo um deles responsável por suportar os esforços mecânicos (reforço) e o outro (matriz) por transferir os esforços mecânicos externos para o reforço [38].

Esses materiais vêm sendo usados desde o início dos anos 1960 nos segmentos de materiais de alta-performance. Os polímeros reforçados com fibra de vidro começaram a ser estudados vinte anos mais tarde [54].

São geralmente usados porque têm propriedades desejáveis que não podem ser alcançadas por quaisquer um dos materiais individualmente, dentre elas temos:

$>$ Baixa condutibilidade elétrica;

> Alta resistência à corrosão química;

$>$ Alto módulo de elasticidade;

> Densidade menor que a do aço e alumínio; 
> Podem ser fabricados em diversas cores e formatos;

$>$ Alta resistência mecânica.

As propriedades dos compósitos são uma função das propriedades de suas fases constituintes e da geometria do reforço, a qual compreende forma, tamanho, quantidade, distribuição e orientação das fibras ou partículas [56].

Quatro tipos de matrizes são utilizadas em compósitos: polimérica, metálica, cerâmica e de carbono. As matrizes metálicas são recomendadas para aplicações sujeitas a altas temperaturas, aproximadamente $800^{\circ} \mathrm{C}$. Para aplicações que precisam resistir a altíssimas temperaturas, acima de $1000^{\circ} \mathrm{C}$, são usadas matrizes cerâmicas [50, 56].

\subsubsection{Compósitos Poliméricos}

Os compósitos poliméricos são materiais conjugados formados por pelo menos duas fases ou dois componentes ou ainda são misturas de materiais cerâmicos ou metálicos com uma matriz polimérica. Para a formação do material compósito ou do material conjugado é necessário haver uma interação química e/ou física entre o componente e a matriz polimérica proporcionando a transferência de esforços mecânicos. São os compósitos mais utilizados e o que os difere entre si é o tipo de arquitetura do reforço, que confere ao compósito, propriedades elásticas de resistência à deformação plástica, fluência e ao uso melhores que as do polímero sem carga [50, 57]. Em um compósito de matriz polimérica e fibra de vidro, por exemplo, a fibra confere resistência mecânica enquanto que a matriz é responsável pela flexibilidade [3].

Assim, os seguintes fatores são fundamentais para as propriedades [77]:

> Propriedades dos componentes individuais e composição;

$>$ Interação entre as fases;

> Razão de aspecto e porosidade da carga;

> Dispersão do reforço.

Ao se adicionar uma carga a um polímero, objetiva-se a obtenção de um novo material com propriedades intermediárias entre aquelas dos dois componentes. Esse comportamento é previsto para a propriedade $(P)$ de um 
compósito, através da regra das misturas. A equação geral desta regra é dada por:

$$
P=P_{a} \cdot V_{a}+P_{b} \cdot V_{b}
$$

Onde:

Os índices a e $b$ referem-se aos componentes (matriz e fase dispersa) e $V$ é a fração volumétrica [77].

Por outro lado, a previsão destas propriedades mecânicas em compósitos de fibra curta é dificultada, devido ao largo espectro de comprimentos e orientações que as fibras apresentam que é conseqüência do processamento do compósito [78].

\subsubsection{Preparação de compósitos termoplásticos}

Vários processos de transformação de termoplásticos têm sido usados na produção de compósitos poliméricos. Em se tratando de compósitos de matriz termoplástica, como neste caso, o processo de extrusão vem sendo o mais reportado em artigos científicos e utilizado industrialmente, principalmente extrusoras de dupla-rosca, onde duas roscas intercaladas giram lado a lado dentro de um cilindro de furo interno. As roscas podem ambas girar no mesmo sentido (co-rotacional) ou em sentido oposto (contra-rotacional - Figura 2.19). As principais vantagens do processamento de compósitos termoplásticos em extrusora dupla-rosca são: flexibilidade na configuração da geometria da rosca, dosagem de material em diferentes pontos da extrusora e controle preciso da dosagem através de alimentadores. A ação da mistura é mais eficiente no caso das roscas co-rotacionais que nas contra-rotacionais, devido à maior alternância de fluxo de uma rosca para outra [58].

A extrusora é caracterizada pelo diâmetro $D$ e pelo comprimento $L$ da rosca. A vazão total de uma extrusora varia conforme $D^{2}$, desde que não existam alterações de outros parâmetros. Já a capacidade de troca de calor entre o polímero e a extrusora depende do tempo de residência e, portanto do $L$, se a velocidade da rosca é constante [29]. 


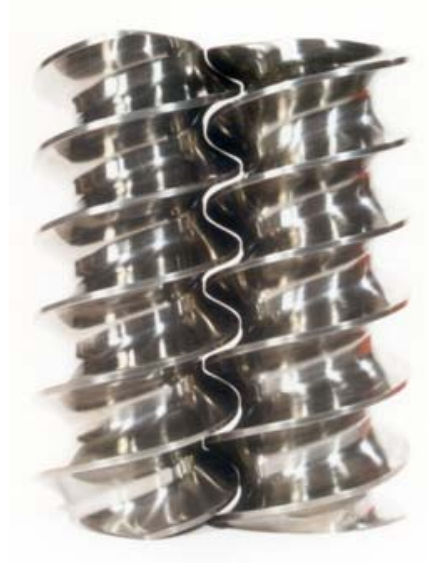

Figura 2.19 llustração de parte de um conjunto rosca co-rotacional.

Vale comentar que até o presente não foram localizados estudos que contemplassem a adição de caco de vidro moído (pó de vidro) em poliamidas 6 ou 6.6 . 


\section{MATERIAIS E MÉTODOS}

Neste estudo foram empregadas as cargas mais utilizadas na indústria de produção de compósitos a fim de compará-los em termos de propriedades e processamento com o compósito obtido com a adição de vidro em pó.

As etapas de processamento dos compósitos, a obtenção dos corpos de prova e a avaliação das propriedades mecânicas foram realizadas nos laboratórios de desenvolvimento da Rhodia Poliamida e Especialidades Ltda. (São Bernardo do Campo).

\subsection{Descrição dos materiais}

\subsubsection{Poliamida 6.6 - Technyl A200 Natural}

Foi utilizada a poliamida 6.6 (Rhodia Poliamida e Especialidades), na forma de "Pellets" (grãos), nomenclatura Technyl A 200 [59]. Na Tabela 3.1 são apresentadas as características deste polímero de maior interesse neste estudo.

Tabela 3.1: Características do polímero empregado [59].

\begin{tabular}{|c|c|c|}
\hline \multicolumn{1}{|c|}{ Propriedades Mecânicas } & Normas & $\begin{array}{c}\text { Valores } \\
(\text { Eh0 })^{(1)}\end{array}$ \\
\hline Módulo de elasticidade na tração (MPa) & ISO R527 & 3000 \\
\hline Resistência na ruptura (Mpa) & ISO R527 & 55 \\
\hline Alongamento na ruptura (\%) & ISO R527 & 40 \\
\hline Resistência ao impacto Charpy sem entalhe $\left(\mathrm{KJ} / \mathrm{m}^{2}\right)$ & ISO 179 & Não Quebra \\
\hline
\end{tabular}

${ }^{(1)}$ Material seco como moldado

\subsubsection{Cargas e reforços comerciais}

\subsubsection{Talco - TALMAG P 20}

As Tabelas 3.2 e 3.3 apresentam valores típicos de composição e granulometria para o talco TALMAG P20 produzido pela empresa Magnesita 
S.A. [60] que foi utilizado neste estudo.

Tabelas 3.2:e 3.3: Valores típicos de composição química e granulometria para o talco.

\begin{tabular}{|c|c|}
\hline Componente & $\begin{array}{c}\text { Valor Típico } \\
(\%)\end{array}$ \\
\hline $\mathrm{MgO}$ & 31,7 \\
\hline $\mathrm{SiO}_{2}$ & 63,5 \\
\hline $\mathrm{H}_{2} \mathrm{O}$ & 4,8 \\
\hline
\end{tabular}

Diâmetro das partículas

\begin{tabular}{|c|c|c|c|c|}
\hline Sedigraph & D99 & D75 & D50 & D10 \\
\hline$\mu \mathrm{m}$ (máx.) & 19 & 6,5 & 4,5 & 1,8 \\
\hline
\end{tabular}

\subsubsection{Fibra de Vidro - DS 1109}

A Tabela 3.4 apresenta as características típicas da fibra de vidro DS 1109 (Owens Corning) [61] utilizada neste estudo.

Tabela 3.4 Propriedades típicas da fibra de vidro DS 1109.

\begin{tabular}{|c|c|}
\hline Característica & Valor Típico \\
\hline Comprimento $(\mathrm{mm})$ & 4,5 \\
\hline Diâmetro do filamento $(\mu \mathrm{m})$ & 10 \\
\hline Perda ao fogo $(\%)$ & 0,65 \\
\hline Umidade (\%) & 0,10 máximo \\
\hline
\end{tabular}

\subsubsection{Micro esfera de vidro 3000 CP0302}

As Tabelas 3.5 e 3.6 a seguir apresentam algumas das propriedades típicas da micro esfera de vidro tipo 3000 CP0302, da empresa Potters Industrial Ltda. [44] que foi utilizada neste estudo. 
Tabelas 3.5 e 3.6: Propriedades típicas da micro esfera de vidro 3000 CP0302.

\begin{tabular}{|c|c|}
\hline Característica & Valores \\
\hline Composição & Vidro Borossilicato \\
\hline Densidade $\left(\mathrm{g} / \mathrm{cm}^{3}\right)$ & 2,5 \\
\hline Área superficial $\left(\mathrm{cm}^{2} / \mathrm{g}\right)$ & $4000-8000$ \\
\hline Tratamento superficial & Silano \\
\hline Constante dielétrica, $22^{\circ} \mathrm{C}, 106 \mathrm{~Hz}$ & 5,8 \\
\hline
\end{tabular}

Diâmetro das partículas

\begin{tabular}{|c|c|c|c|c|}
\hline \multicolumn{1}{|c|}{$\mu \mathrm{m}$} & $\leq 24$ & $\leq 45$ & $\leq 63$ & $\leq 100$ \\
\hline \% vol & $45-75$ & $85-100$ & $95-100$ & 100 \\
\hline
\end{tabular}

\subsubsection{Wollastonita 10 WOLLASTOCOAT.}

As Tabelas 3.7 e 3.8 apresentam uma composição química típica

(Tabela 3.7) e propriedades típicas (Tabela 3.8) da wollastonita 10 Wollastocoat da empresa NYCO Minerals utilizada neste estudo [62].

Tabela 3.7: Composição química típica da wollastonita 10 Wollastocoat.

\begin{tabular}{|c|c|}
\hline Componente & $\begin{array}{c}\text { Valor Típico } \\
(\%)\end{array}$ \\
\hline $\mathrm{CaO}$ & 46,15 \\
\hline $\mathrm{SiO}_{2}$ & 51,60 \\
\hline $\mathrm{Fe}_{2} \mathrm{O}_{3}$ & 0,77 \\
\hline $\mathrm{Al}_{2} \mathrm{O}_{3}$ & 0,34 \\
\hline $\mathrm{MnO}$ & 0,16 \\
\hline $\mathrm{MgO}$ & 0,38 \\
\hline $\mathrm{TiO}_{2}$ & 0,05 \\
\hline $\mathrm{K}_{2} \mathrm{O}$ & 0,05 \\
\hline Perda de & 0,50 \\
\hline Massa $\left(1000^{\circ} \mathrm{C}\right)$ & \\
\hline
\end{tabular}


Tabela 3.8: Propriedades típicas da wollastonita 10 Wollastocoat.

\begin{tabular}{|c|c|c|}
\hline \multicolumn{1}{|c|}{ Característica } & Valor & Método \\
\hline Brilho G.E. & 95 & ASTM E 97 \\
\hline \begin{tabular}{c|c|c|}
\hline Absorção de óleo \\
(lbs./100 lbs.)
\end{tabular} & 24 & ASTM D281 \\
\hline Densidade (g/cm $\left.{ }^{3}\right)$ & 2,9 & --- \\
\hline Tamanho médio de partícula $(\mu \mathrm{m})$ & 3 & Cilas Granulometer \\
\hline Área superficial (m²/g) (BET) & 4,1 & ASAP 2405 \\
\hline Retido em malha 200 U.S. Mesh (\%) & 100 & Alpine Jet Sieve \\
\hline Umidade (\%) & 0,15 & Karl Fischer \\
\hline Cor & Branco & ------ \\
\hline Morfologia & Acicular & ------ \\
\hline
\end{tabular}

\subsubsection{Caco de vidro}

Uma amostra de caco de vidro incolor, de aproximadamente $15 \mathrm{~kg}$, foi fornecida pela empresa Saint-Gobain Vidros Brasil e é proveniente de um lote único de garrafas para bebidas e apresenta a seguinte composição química média em massa (Tabela 3.9) [63].

Tabela 3.9: Composição química do vidro.

\begin{tabular}{|c|c|c|c|c|c|c|}
\hline $\mathrm{SiO}_{2}$ & $\mathrm{Na}_{2} \mathrm{O}$ & $\mathrm{CaO}$ & $\mathrm{MgO}$ & $\mathrm{Al}_{2} \mathrm{O}_{3}$ & $\begin{array}{c}\mathrm{FeO} / \\
\mathrm{Fe}_{2} \mathrm{O}_{3}\end{array}$ & $\mathrm{~K}_{2} \mathrm{O}$ \\
\hline $72,8 \%$ & $13,2 \%$ & $11,2 \%$ & $0,16 \%$ & $2,13 \%$ & $0,039 \%$ & $0,09 \%$ \\
\hline
\end{tabular}

\subsection{Descrição dos Métodos}

\subsubsection{Obtenção e moagem do caco de vidro}

Para a obtenção do caco de vidro, as garrafas foram lavadas, secas em estufa e manualmente fragmentadas em partículas da ordem de 1,5 cm. Esse material em seguida foi reduzido em fragmentos menores com o auxílio de um moinho de facas instalado no laboratório de Desenvolvimento da Rhodia Poliamida e Especialidades com o objetivo de reduzir e homogeneizar a granulometria. A seguir avaliamos a distribuição granulométrica deste material, 
com o auxílio de um equipamento Granutest (Figura 3.1) em quatro frações de $1 \mathrm{~kg}$ por 15 minutos e rotação 9. Utilizamos parte da série Tyler para a separação das frações (Figura 3.2).

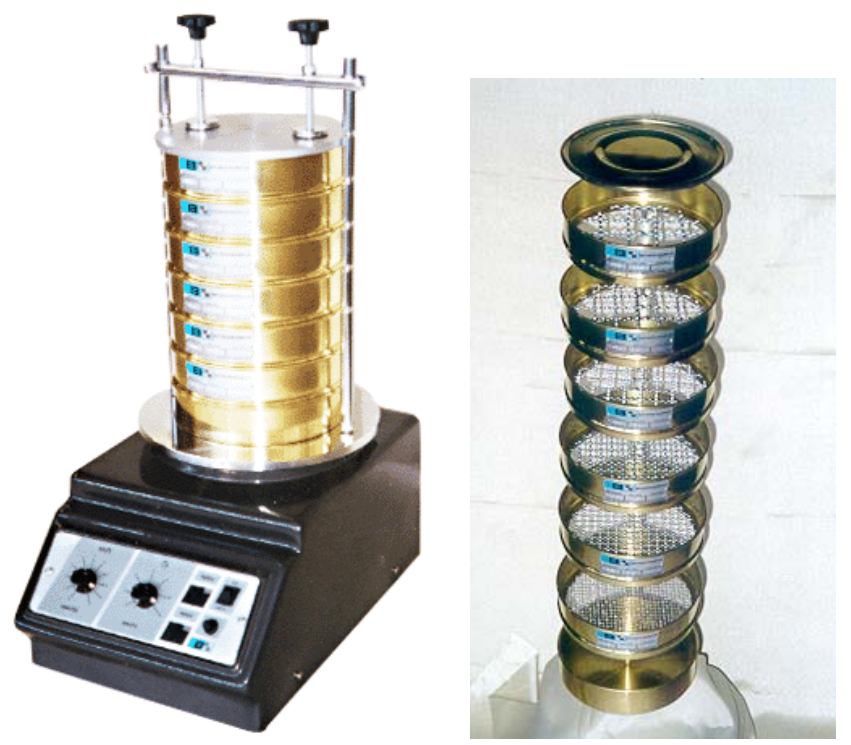

Figuras 3.1 e 3.2: Agitador eletro-magnético (tipo Granutest) e conjunto de peneiras Tyler [64]

Como ainda assim as partículas eram inadequadas para 0 processamento, decidiu-se, reduzir o seu tamanho médio com o auxílio de um moinho de bolas de porcelana por dez horas (amostra 1) e um moinho de bolas de alta alumina por doze horas e trinta minutos (amostra 2), ambos instalados no laboratório de Cerâmica da escola SENAI. Nos dois processos foram colocados $10 \mathrm{~kg}$ do caco de vidro e com aproximadamente quatro horas de moagem uma amostra foi retirada para verificação do tamanho da partícula.

Através de avaliação visual concluiu-se que o processo foi ineficiente. Retornou-se o material para moagem por mais seis horas e analisou-se o material em malha \#200 e obteve-se $20 \%$ de material retido. O processo se estendeu por mais duas horas no moinho de bolas de porcelana e por mais quatro horas e trinta minutos no moinho de bolas de alta alumina.

\subsubsection{Preparação dos compósitos (Extrusão)}

Os compósitos foram obtidos a partir de uma extrusora dupla rosca co-rotacional ZSK-30 (diâmetro $D=30$ mm e L/D=35) da marca Werner \& Pfleiderer, com cinco zonas de aquecimento, sendo quatro zonas no cilindro e 
uma no cabeçote. Possui sistema de rosca/cilindro segmentado e com alimentadores/dosadores acoplados ao longo do cilindro.

A poliamida 6.6 em grânulos foi introduzida no funil de alimentação da extrusora dupla rosca, sendo sua dosagem rigorosamente controlada por uma balança gravimétrica específica para materiais granulados ou particulados. As cargas foram introduzidas no terceiro ponto do cilindro, sendo que nessa posição o polímero já está no estado fundido o que possibilita uma melhor incorporação da mesma. Os teores de cada carga foram rigorosamente controlados por uma balança gravimétrica lateral, específica para dosagem de particulados.

O perfil de roscas contém inicialmente elementos de condução, seguidos por elementos de mistura e elementos de transporte, que se posicionam também na zona de degasagem e que vão até a matriz da extrusora.

A proposta inicial era estudar compósitos com teores de 5\% e 10\% de carga (primeira fase), no entanto, como não foi possível estabilizar a balança dosadora de cargas para a adição de 5\% de vidro moído, decidiu-se estudar também os compósitos com adição de 15 e 20\% de cada uma das cargas em uma segunda fase.

Nesta segunda fase decidi-se incluir também a obtenção de um compósito com wollastonita.

Na Tabela 3.10 é apresentada a proposta de composição de cada formulação da primeira fase. As condições de processamento para todos os compósitos foram: rotação máxima de rosca de 240 RPM e perfil de temperatura de $265^{\circ} \mathrm{C}$ (zona 1$)$ a $280^{\circ} \mathrm{C}$ (zona 5).

Foram preparados aproximadamente $5 \mathrm{~kg}$ de cada compósito. Após a extrusão, os materiais foram acondicionados em embalagens herméticas para evitar a absorção de água, que é prejudicial ao processo posterior de injeção de corpos de prova, pois a presença da água promove a degradação oxidativa da poliamida. 
Tabela 3.10: Composição dos compósitos poliméricos obtidos na primeira fase do estudo.

\begin{tabular}{|l|l|l|l|l|l|l|l|l|l|l|}
\hline Composição da Formulação (\%p/p) & 1 & 2 & 3 & 4 & 5 & 6 & 7 & $8^{*}$ & 9 \\
\hline A 200 Natural & 100 & 95 & 90 & 95 & 90 & 95 & 90 & 95 & 90 \\
\hline Talco & & 5 & 10 & & & & & & \\
\hline Fibra de vidro & & & & 5 & 10 & & & & \\
\hline Micro esfera de vidro & & & & & & 5 & 10 & & \\
\hline Vidro moído & & & & & & & & 5 & 10 \\
\hline
\end{tabular}

*não foi possível processar este compósito pela instabilidade de dosagem da balança.

Já na Tabela 3.11 é apresentada a composição das formulações da segunda fase sendo observadas as mesmas condições de processamento para todos os compósitos.

Tabela 3.11: Composição dos compósitos poliméricos obtidos na segunda fase do estudo.

\begin{tabular}{|l|l|l|l|l|l|l|l|l|l|l|l|l|}
\hline Composição da Formulação (\%p/p) & 10 & 11 & 12 & 13 & 14 & 15 & 16 & 17 & 18 & 19 & 20 \\
\hline A 200 Natural & 85 & 80 & 85 & 80 & 85 & 80 & 85 & 80 & 90 & 85 & 80 \\
\hline Talco & 15 & 20 & & & & & & & & & \\
\hline Fibra de vidro & & & 15 & 20 & & & & & & & \\
\hline Micro esfera de vidro & & & & & 15 & 20 & & & & & \\
\hline Vidro moído & & & & & & & 15 & 20 & & & \\
\hline Wollastonita & & & & & & & & & 10 & 15 & 20 \\
\hline
\end{tabular}

\subsubsection{Injeção dos corpos de prova}

A injeção dos corpos de prova para realização dos ensaios mecânicos foi realizada em uma máquina injetora Romi R65 Primax, com perfil de temperatura do cilindro de $285^{\circ} \mathrm{C}$ (zona 1) a $270^{\circ} \mathrm{C}$ (zona 4) e temperatura do molde de $80^{\circ} \mathrm{C}$.

Foram injetados corpos de prova para os ensaios de resistência à 
tração, à flexão, ao impacto Charpy e contração, conforme normas estabelecidas para cada ensaio.

Os tempos de estabilização das amostras antes da realização dos ensaios foram respeitados de acordo com as normas utilizadas.

\subsection{Técnicas de Caracterização}

\subsubsection{Análise de distribuição do tamanho de partículas}

Além do sistema de peneiras (Granutest) utilizado em uma avaliação prévia do tamanho de partículas do caco moído, analisamos a distribuição do tamanho de partículas das amostras obtidas pela moagem em moinho de bolas de alta alumina (amostra 1 equivale à dez horas de moagem) e em moinho de bolas de porcelana (amostra 2 equivale à doze horas de moagem) com o auxílio de um analisador de tamanho de partículas modelo LS 100Q - Coulter que é um aparelho utilizado para medir o tamanho das partículas, ou mais especificamente, a distribuição dos diferentes tamanhos de partículas em uma amostra através da difração de raio laser em uma unidade de dispersão aquosa. Utiliza um modelo ótico de acordo com os princípios de medidas de Mie e Fraunhofer [65].

\subsubsection{Avaliação da interação da poliamida 6.6 e carga mineral por Microscopia Eletrônica de Varredura (MEV).}

Para a análise de microscopia eletrônica de varredura foram utilizadas amostras fraturadas em temperatura ambiente, resultantes do ensaio de resistência ao impacto CHARPY devido ao caráter de fratura frágil destas amostras.

Nesta técnica um feixe de elétrons primários, com diâmetro que pode variar de alguns nanômetros a um micrometro, é focalizado sobre um ponto de uma amostra com o auxílio de lentes eletromagnéticas. A seguir, o feixe é deslocado para um ponto vizinho e assim sucessivamente na horizontal e na vertical, varrendo a superfície numa área escolhida. A intensidade dos elétrons reemitidos em cada ponto pela superfície depende da orientação e composição daquele ponto. Esses elétrons (retroespalhados ou secundários) são coletados por um detector e o sinal elétrico obtido é amplificado [79]. 
As micrografias foram obtidas utilizando-se o microscópio eletrônico de varredura marca Philips, modelo XI-30 com microssonda EDAX instalado no Laboratório de Microscopia Eletrônica do Departamento de Engenharia Metalúrgica e de Materiais da Poli-USP.

\subsubsection{Propriedades Mecânicas}

As propriedades mecânicas são parâmetros ou características do material que compreendem a resposta dos materiais às influências mecânicas externas, manifestadas pela capacidade de desenvolverem deformações reversíveis e irreversíveis, e resistirem à fratura. A natureza dessa resposta depende da temperatura e do tempo, bem como da estrutura do material, do peso molecular e das condições de ensaio e preparação da amostra [78]. Essas características dos polímeros são geralmente avaliadas por meio de ensaios, que indicam dependências tensão-deformação, que, todavia são insuficientes para descrever os materiais poliméricos, também a nível molecular. Assim, as características dos polímeros, que se refletem nas suas propriedades mecânicas, podem ser quantificadas através de métodos cujo empirismo é contrabalançando pelo rigor das condições, estabelecidas nas normas técnicas. As propriedades mecânicas mais importantes decorrem de processos onde há grandes relaxações moleculares, como relaxação sob tensão, escoamento sob peso constante e histerese. Essas relaxações dependem muito da temperatura, da capacidade de desenvolver deformações reversíveis pronunciadas, que são maiores em elastômeros, bem como da íntima correlação entre processos mecânicos e químicos, os quais se influenciam mutuamente de modo substancial [66].

\subsubsection{Ensaios de resistência à tração, módulo de elasticidade na tração e alongamento.}

A resistência à tração é um conjunto de testes realizados em laboratório para determinar resistência, elasticidade, alongamento e ponto de ruptura de diversos materiais [3].

As propriedades de tensão constituem-se nos mais importantes indicadores da resistência mecânica de um material. A força necessária para 
alongar um corpo de prova é determinada juntamente com a quantidade total de material estirada da quebra do referido corpo.

Corpos de prova para determinação de propriedade de tensão podem ser injetados ou prensados sob condições padrão. A espessura típica é de 1/8 polegada, porém as demais dimensões podem variar (Figura 3.3).

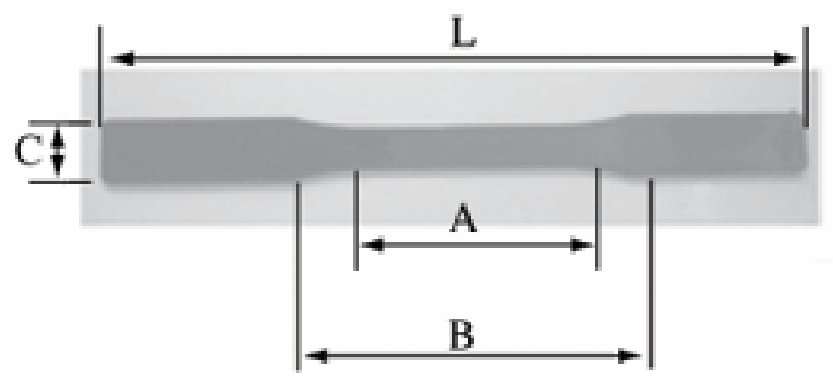

Figura 3.3: Corpo de prova de resistência à tração conforme norma ASTM D638 [67]

Onde $A=60 \mathrm{~mm} ; B=100 \mathrm{~mm} ; C=19 \mathrm{~mm}$ e espessura $=3 \mathrm{~mm}$ e $\mathrm{L}=215 \mathrm{~mm}$

O módulo de elasticidade é essencialmente uma medida da rigidez do material, sendo muito útil na escolha de um polímero para uma dada aplicação. Pode-se estabelecer que o material ideal para certo produto deva exibir comportamento, quando em uso normal, idêntico ao observado na região em que o modulo é medido. Desta forma seria possível garantir a manutenção das características elásticas (deformação proporcional à tensão), em condições de serviço.

Já o alongamento é a medida da ductilidade de um material, determinada em um teste de tração. É o aumento no comprimento útil medido após a ruptura dividido pelo comprimento útil original. Um maior alongamento indica uma maior ductilidade.

O alongamento não pode ser usado para prever o comportamento de materiais submetidos a cargas repentinas ou repetidas.

Com o objetivo de analisar o comportamento de módulo elástico na tração, resistência à tração e alongamento na ruptura em função da carga, foram utilizados corpos de prova (no mínimo dez), e a Máquina Universal de Ensaios EMIC DL 2000 conforme a Norma ASTM D638-97 [67]. 
A velocidade utilizada para estes ensaios foi de $5 \mathrm{~mm} /$ minuto, com temperatura controlada de $23^{\circ} \mathrm{C} \pm 1^{\circ} \mathrm{C}$, conforme norma e utilizou-se um extensômetro EMIC.

Nos ensaios de tração, os corpos de prova são fixados em dispositivos chamados de garras. As garras são acopladas à travessa fixa e à travessa móvel da Máquina Universal de Ensaios. A taxa de deformação de tração é controlada pelo mecanismo de direcionamento, enquanto a tensão de tração sustentada pela amostra é registrada pela célula de carga, ambos acoplados à travessa fixa. $\mathrm{O}$ extensômetro deve ser fixado corretamente, pois do contrário haverá o "escorregamento" do corpo de prova e em conseqüência a leitura incorreta da taxa de alongamento.

\subsubsection{Ensaios de resistência ao impacto}

A capacidade de um determinado material de absorver energia do impacto está ligada à sua tenacidade, que por sua vez está relacionada com a sua resistência e ductilidade.

O ensaio de resistência ao impacto dá informações da capacidade do material absorver e dissipar essa energia.

Como resultado do ensaio de choque obtém-se a energia absorvida pelo material até sua fratura, caracterizando assim o comportamento dúctilfrágil.

O ensaio de impacto CHARPY foi realizado de acordo com a Norma ISO 179 [68] Neste ensaio, utilizou-se um pêndulo de $25 \mathrm{~J}$ para o compósito sem carga e o de $5 \mathrm{~J}$ para os demais compósitos e velocidade de $2,9 \mathrm{~m} / \mathrm{s}$.

\subsubsection{Determinação do teor de carga}

A fim de garantir a dosagem das cargas foi realizada a análise do teor utilizando-se o método interno Rhodia (DCA 3J 219) que se baseia na perda de massa de um grama do compósito após a calcinação (queima) a $800^{\circ} \mathrm{C}$ por 5 minutos em forno mufla por microondas o que equivale a 30 minutos em forno mufla convencional (elétrico).

\subsubsection{Determinação da estabilidade dimensional}

Devido à natureza cristalina, os termoplásticos semicristalinos, como 
a poliamida 6.6, exibem um considerável encolhimento no resfriamento a partir da fusão e isso pode gerar problemas de qualidade nas peças. A presença de cargas reduz o nível geral de encolhimento [69].

O objetivo deste teste é verificar o grau de contração após o processo de injeção, tendo como referência as normas ASTM 955 [70] ISO 2577 [71].

Para tanto, dez plaquetas com dimensões $100 \times 100 \times 3 \mathrm{~mm}^{3}$, de cada formulação, foram preparadas. As plaquetas obtidas ficaram em repouso em uma sala climatizada a $(23 \pm 2)^{\circ} \mathrm{C}$ e $(50 \pm 5) \%$ de umidade relativa, por 48 horas. A seguir foram realizadas, com auxílio de um paquímetro, três medidas na direção paralela ao fluxo e três medidas na direção perpendicular ao fluxo de injeção, perfazendo um total de seis medidas por placa. A Figura 3.4 mostra uma foto ilustrativa dessas placas.

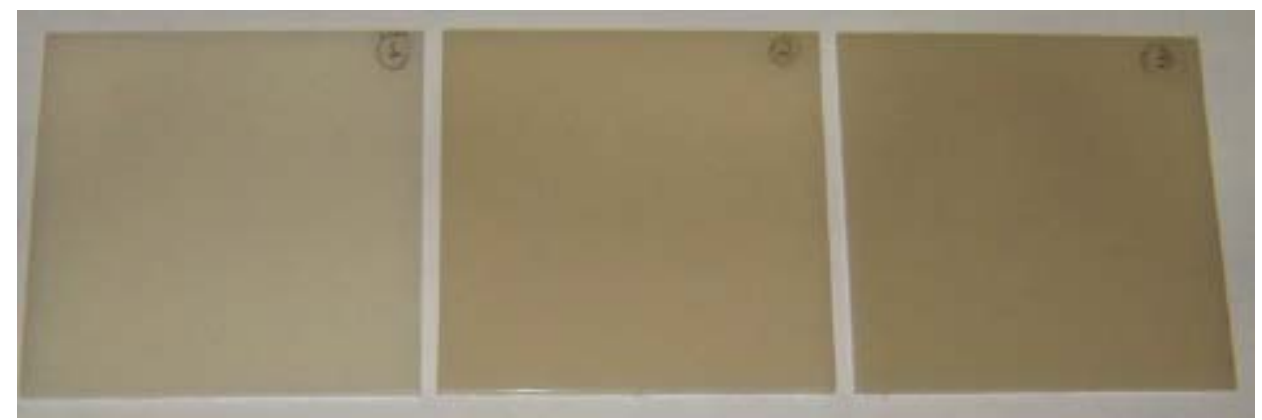

Figura 3.4: Exemplo das placas utilizadas para as medidas de contração [72]. 


\section{RESULTADOS E DISCUSSÃO}

\subsection{Análise do caco moído}

A análise da distribuição do tamanho de partículas do caco realizada nas amostras (1 a 4) após moagem em moinho de facas, mostrou a distribuição apresentada na Tabela 4.1.

Tabela 4.1: Distribuição do tamanho de partícula do caco de vidro moído em moinho de facas.

\begin{tabular}{|c|c|c|c|c|c|}
\hline $\begin{array}{c}\text { Tyler } \\
(\text { Mesh })\end{array}$ & $\begin{array}{c}\text { Abertura } \\
(\mu \mathrm{m})\end{array}$ & $\begin{array}{c}1 \\
(\% \mathrm{p} / \mathrm{p})\end{array}$ & $\begin{array}{c}2 \\
(\% \mathrm{p} / \mathrm{p})\end{array}$ & $\begin{array}{c}3 \\
(\% \mathrm{p} / \mathrm{p})\end{array}$ & $\begin{array}{c}4 \\
(\% \mathrm{p} / \mathrm{p})\end{array}$ \\
\hline 28 & 589 & 56,7 & 62,4 & 60,3 & 62,8 \\
\hline 35 & 500 & 11,6 & 10,9 & 11,0 & 10,7 \\
\hline 250 & 63 & 29,2 & 24,6 & 26,4 & 24,4 \\
\hline Fundo & ------ & 2,5 & 2,1 & 2,3 & 2,2 \\
\hline
\end{tabular}

Esta distribuição não é adequada para o preparo de amostras comparativas do compósito por extrusão, uma vez que o material moído apresentou uma quantidade de partículas de dimensões grandes, muito maior do que aquela das outras cargas comerciais, tais como a micro esfera de vidro, por exemplo, que possui diâmetro médio de partícula de apenas $63 \mu \mathrm{m}$.

Assim, uma nova etapa de moagem foi estabelecida utilizando-se moinhos de bolas.

A Tabela 4.2 apresenta os resultados da distribuição obtida para a amostra formada pela mistura em partes iguais da amostra com dez horas (amostra 1) e com doze horas e trinta minutos (amostra 2) de moagem. As amostras 1 e 2 foram homogeneizadas para a obtenção de uma amostra mista. 
Tabela 4.2: Tamanhos médios das partículas do vidro em pó, obtidos com o equipamento Coulter LS 100Q, após moinho de bolas.

\begin{tabular}{|c|c|}
\hline \multicolumn{1}{|c|}{} & Amostra Mista \\
\hline Média $(\mu \mathrm{m})$ & 34 \\
\hline D10 $(\mu \mathrm{m})$ & 2 \\
\hline D50 $(\mu \mathrm{m})$ & 20 \\
\hline D90 $(\mu \mathrm{m})$ & 89 \\
\hline
\end{tabular}

\subsection{Determinação do teor de carga}

A fim de se verificar a dosagem correta das cargas, foi determinado o teor de carga de cada uma das formulações preparadas, conforme método interno Rhodia (DCA 3J 219). Os resultados são apresentados na Tabela 4.3.

Tabela 4.3: Teor de carga das formulações utilizadas neste estudo.

\begin{tabular}{|c|c|}
\hline Formulação & Média (\%) \\
\hline sem carga & 0 \\
\hline $10 \%$ talco & 9,3 \\
\hline $10 \%$ fibra vidro & 10,5 \\
\hline $10 \%$ micro esfera & 11,4 \\
\hline $10 \%$ vidro & 10,3 \\
\hline $15 \%$ talco & 15,4 \\
\hline $20 \%$ talco & 20,5 \\
\hline $15 \%$ fibra vidro & 20,0 \\
\hline $20 \%$ fibra vidro & 19,9 \\
\hline $15 \%$ micro esfera & 13,9 \\
\hline $20 \%$ micro esfera & 19,1 \\
\hline $15 \%$ vidro & 15,3 \\
\hline $20 \%$ vidro & 18,5 \\
\hline $10 \%$ wollastonita & 10,4 \\
\hline $15 \%$ wollastonita & 14,8 \\
\hline F20 - 20\% wollastonita & 19,5 \\
\hline
\end{tabular}


Todos os resultados são provenientes do cálculo da média de no mínimo três amostras coletadas durante o processo de extrusão e se observa valores reais próximos dos valores teóricos, exceção feita à amostra com 15\% teórico de fibra de vidro.

\subsection{Avaliação de propriedades mecânicas}

Considerando que a proposta deste estudo é obter um compósito que possa ser utilizado em diversas aplicações é de fundamental importância a avaliação das principais propriedades mecânicas. Estes resultados são referentes à média de dez corpos de prova conforme recomenda a norma de cada análise.

Como já visto no capítulo 2, o desempenho de compósitos termoplásticos depende das propriedades intrínsecas e dos teores de seus componentes, da qualidade da interface fibra/matriz e das propriedades cristalinas da matriz. Uma boa adesão interfacial, influenciada pela presença de agentes de compatibilização e acoplamento ("sizing"), é normalmente observada em compósitos reforçados por fibras de vidro e micro esferas de vidro e será responsável por uma elevação das propriedades dos compósitos [5].

\subsubsection{Alongamento na ruptura}

A Tabela 4.4 apresenta os resultados obtidos para os compósitos com teores de adição de 10\%, 15\% e 20\% para cada uma das cargas em comparação com o polímero sem carga para a avaliação do alongamento na ruptura e a Figura 4.1 apresenta o gráfico que representa o comportamento deste estudo. 
Tabela 4.4: Determinação do alongamento na ruptura (\%) para o polímero puro e os compósitos.

\begin{tabular}{|l|c|c|c|c|c|c|}
\hline \begin{tabular}{l|l|l|l|l|} 
Teor \\
$(\%)$
\end{tabular} & $\begin{array}{c}\text { Sem } \\
\text { carga }\end{array}$ & Talco & $\begin{array}{c}\text { Fibra de } \\
\text { Vidro }(1)\end{array}$ & $\begin{array}{c}\text { Micro esfera } \\
\text { de Vidro }\end{array}$ & Wollastonita & Vidro Moído \\
\hline 0 & $5,3 \pm 0,8$ & ----- & ---- & ---- & ---- & ---- \\
\hline 10 & & $8,5 \pm 2,1$ & $2,4 \pm 0,1$ & $3,0 \pm 0,3$ & $12,2 \pm 3,6$ & $4,8 \pm 1,0$ \\
\hline 15 & & $5,3 \pm 0,5$ & $2,6 \pm 0,1$ & $2,9 \pm 0,3$ & $7,6 \pm 1,3$ & $6,6 \pm 1,2$ \\
\hline 20 & & $4,4 \pm 0,3$ & $2,7 \pm 0,1$ & $3,0 \pm 0,2$ & $6,0 \pm 0,4$ & $5,7 \pm 1,0$ \\
\hline
\end{tabular}

(1) A amostra com $15 \%$ teórico de fibra de vidro, apresentou teor real de $20 \%$.

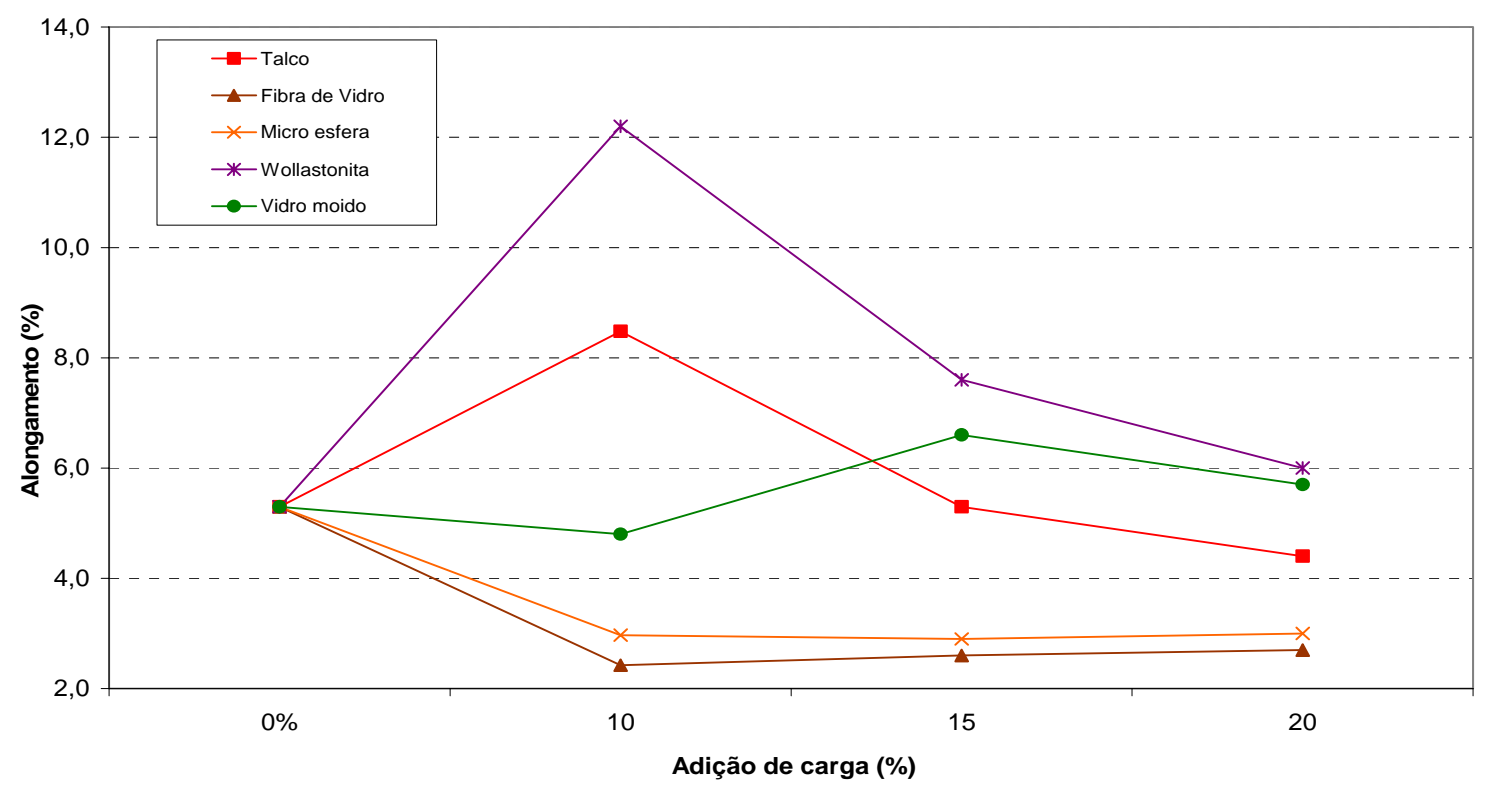

Figura 4.1: Representação do alongamento médio na ruptura (\%).

Sabe-se que, o alongamento máximo na ruptura diminui com o aumento dos teores de carga e esta tendência é causada pelo aumento do caráter quebradiço do compósito em relação ao polímero puro [5]. Entretanto, avaliando-se os resultados não se observa este efeito para os compósitos que com $10 \%$ de talco e $10 \%$ de wollastonita e a propriedade é praticamente inalterada para o aumento do teor de fibra de vidro. A origem deste comportamento talvez possa ser explicada pelo fato de que essas cargas possuem diferentes geometrias, que podem ser observadas nas micrografias apresentadas no item 4.3.6, sendo a wollastonita uma carga acicular e a fibra 
de vidro fibrilar. Para o vidro moído a geometria irregular proveniente do processo de moagem e a ausência de um sistema de acoplagem e compatibilização podem explicar a falta de linearidade dos resultados.

Sabe-se ainda que o alongamento representa o aumento linear percentual do corpo de prova sob tração no momento da ruptura e, portanto, a partir dos dados obtidos pode-se inferir que para os sistemas aqui estudados, este aumento é mais fortemente afetado pelo tipo de reforço do que pelo teor adicionado.

\subsubsection{Resistência à tração na ruptura.}

A Tabela 4.5 apresenta os resultados obtidos para os compósitos com teores de $10 \%, 15 \%$ e $20 \%$ de adição para cada uma das cargas, em comparação com o polímero sem carga, para a avaliação da resistência à tração na ruptura. Para melhor visualização e comparação, a Figura 4.2 apresenta esses mesmos resultados na forma gráfica.

Tabela 4.5: Determinação da resistência à tração na ruptura (MPa) para o polímero puro e os compósitos.

\begin{tabular}{|l|c|c|c|c|c|c|}
\hline \begin{tabular}{|l|l|l|l|l|} 
Teor \\
$(\%)$
\end{tabular} & $\begin{array}{c}\text { Sem } \\
\text { carga }\end{array}$ & Talco & $\begin{array}{c}\text { Fibra de } \\
\text { Vidro }\end{array}$ & $\begin{array}{c}\text { Micro esfera } \\
\text { de Vidro }\end{array}$ & Wollastonita & Vidro Moído \\
\hline 0 & $89 \pm 1$ & ---- & ---- & ---- & ---- & ----- \\
\hline 10 & & $77 \pm 1$ & $98 \pm 4$ & $74 \pm 2$ & $81 \pm 1$ & $78 \pm 1$ \\
\hline 15 & & $73 \pm 1$ & $120 \pm 2$ & $79 \pm 2$ & $80 \pm 1$ & $73 \pm 1$ \\
\hline 20 & & $71 \pm 1$ & $143 \pm 2$ & $83 \pm 1$ & $82 \pm 2$ & $72 \pm 1$ \\
\hline
\end{tabular}

${ }^{(1)}$ A amostra com $15 \%$ teórico de fibra de vidro, apresentou teor real de $20 \%$. 


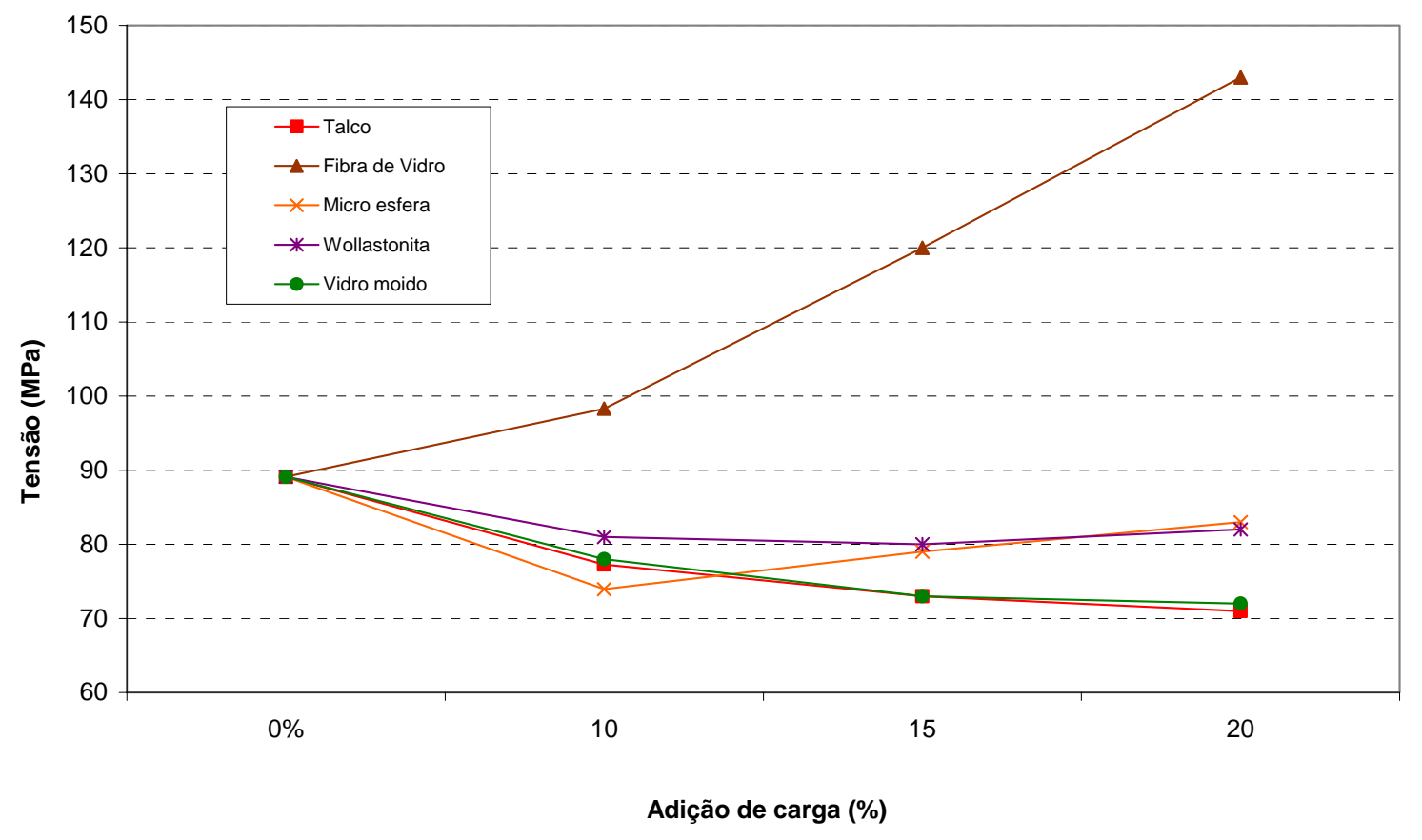

Figura 4.2: Representação da resistência à tração média na ruptura (MPa).

Como já mencionado no capítulo 2, a resistência à tração de materiais compósitos reforçados por fibras depende, principalmente, da resistência e módulo das fibras de reforço; teor, orientação e comprimento das fibras; estabilidade química e resistência da matriz e da interface fibra/matriz. Isto pode justificar o melhor desempenho da fibra de vidro em comparação aos outros tipos de reforço, uma vez que a fibra utilizada neste estudo é a indicada para o uso em poliamida 6.6, por possuir um tratamento superficial de natureza química amino-silano o que promove a interação entre o vidro e a matriz polimérica. O mesmo tipo de tratamento é utilizado na micro esfera de vidro, mas sua geometria esférica não contribui para a melhora da propriedade quando o compósito é comparado ao polímero puro. O compósito com talco pode ter seu desempenho comparado ao do vidro moído.

\subsubsection{Módulo de elasticidade na tração.}

A Tabela 4.6 apresenta os resultados obtidos para os compósitos com teores de adição de 10\%, 15\% e 20\% para cada uma das cargas em comparação com o polímero sem carga para a determinação do módulo de 
elasticidade na tração. O gráfico respectivo é apresentado na Figura 4.3.

Tabela 4.6: Determinação do módulo de elasticidade na tração (MPa) para o polímero puro e os compósitos.

\begin{tabular}{|l|c|c|c|c|c|c|}
\hline $\begin{array}{l}\text { Teor } \\
(\%)\end{array}$ & $\begin{array}{c}\text { Sem } \\
\text { carga }\end{array}$ & Talco & $\begin{array}{c}\text { Fibra de } \\
\text { Vidro }\end{array}$ & $\begin{array}{c}\text { Micro } \\
\text { esfera de } \\
\text { Vidro }\end{array}$ & Wollastonita & Vidro Moído \\
\hline 0 & $3250 \pm 69$ & ----- & ---- & ---- & ---- & ---- \\
\hline 10 & & $4140 \pm 201$ & $4936 \pm 175$ & $3334 \pm 74$ & $4039 \pm 106$ & $3676 \pm 100$ \\
\hline 15 & & $4800 \pm 385$ & $5864 \pm 236$ & $3546 \pm 66$ & $4577 \pm 83$ & $3787 \pm 85$ \\
\hline 20 & & $5171 \pm 305$ & $6833 \pm 162$ & $3732 \pm 79$ & $5339 \pm 135$ & $4340 \pm 549$ \\
\hline
\end{tabular}

${ }^{(1)}$ A amostra com $15 \%$ teórico de fibra de vidro, apresentou teor real de $20 \%$.

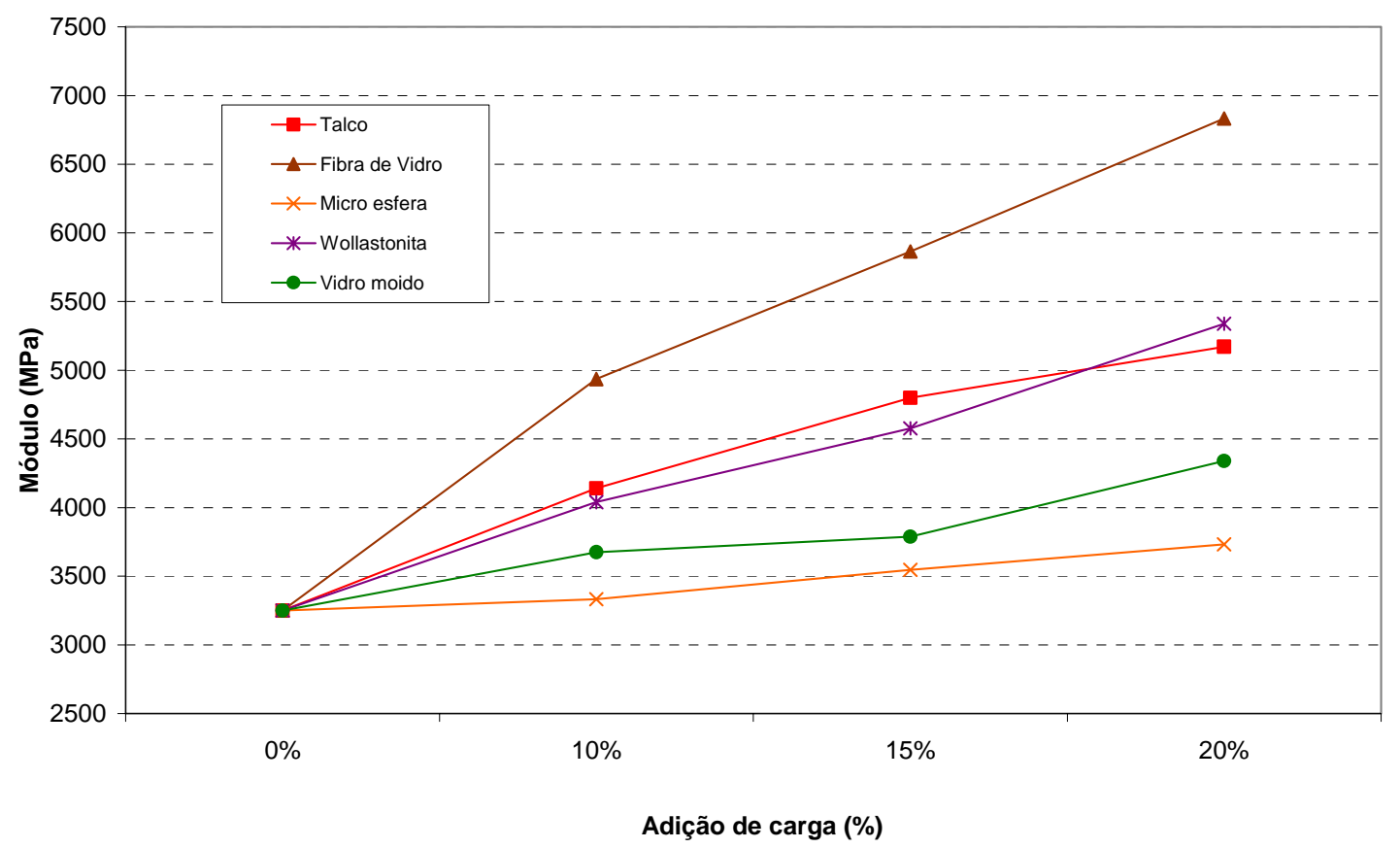

Figura 4.3: Representação do módulo de elasticidade médio na tração.

As cargas sempre aumentam os módulos elásticos de compósitos termoplásticos na medida em que estes materiais são normalmente mais rígidos que os polímeros [31] e o módulo é uma medida de rigidez. Deste modo, é correto verificar-se aumento do módulo em compósitos que apresentaram queda da porcentagem de alongamento. Observa-se que, entre 
as cargas avaliadas neste estudo, a fibra de vidro é mais eficiente, pois além de possuir uma superfície específica maior do que a micro esfera, wollastonita e vidro moído, possui também uma excelente compatibilidade com a matriz polimérica proveniente do recobrimento já mencionado neste capítulo e verificado pela análise das Figuras 4.7 e 4.8. A boa performance do talco pode ser explicada pelo fato de que possui lamelas com elevada razão de aspecto que podem se alinhar paralelamente umas às outras e à superfície moldada, e criar um bom mecanismo de transferência de carga matriz-carga. A irregularidade das partículas do vidro moído parece favorecer esta característica quando comparadas às micro esferas de vidro.

Apesar de verificar-se a diferença entre o valor teórico e o real do teor de fibra de vidro do compósito com 15\%, não foi observado, em nenhuma das propriedades, comportamento condizente com este efeito. Portanto, o mais provável é que tenha ocorrido uma falha na medição do teor das amostras com 15\% teórico e não uma falha de dosagem desta carga.

\subsubsection{Resistência ao impacto Charpy (sem entalhe).}

A Tabela 4.7 apresenta os resultados obtidos para os compósitos com teores de adição de 10\%, 15\% e 20\% para cada uma das cargas em comparação com o polímero sem carga na determinação da resistência ao impacto Charpy sem entalhe e a Figura 4.4 o gráfico que representa o comportamento deste estudo.

Tabela 4.7: Determinação da resistência ao impacto Charpy $\left(\mathrm{KJ} / \mathrm{m}^{2}\right)$ sem entalhe para o polímero puro e os compósitos.

\begin{tabular}{|l|c|c|c|c|c|c|}
\hline \begin{tabular}{l|l|c|c|c|c|} 
Teor \\
$(\%)$
\end{tabular} & $\begin{array}{c}\text { Sem } \\
\text { carga }\end{array}$ & Talco & $\begin{array}{c}\text { Fibra de } \\
\text { Vidro }\end{array}$ & $\begin{array}{c}\text { Micro esfera } \\
\text { de Vidro }\end{array}$ & Wollastonita & Vidro Moído \\
\hline 0 & $208 \pm 163$ & ----- & ---- & ---- & ---- & ---- \\
\hline 10 & & $75 \pm 4$ & $29 \pm 1$ & $20 \pm 1$ & $89 \pm 13$ & $33 \pm 13$ \\
\hline 15 & & $33 \pm 2$ & $33 \pm 2$ & $18 \pm 1$ & $79 \pm 2$ & $25 \pm 7$ \\
\hline 20 & & $47 \pm 1$ & $41 \pm 2$ & $20 \pm 1$ & $57 \pm 1$ & $25 \pm 6$ \\
\hline
\end{tabular}

${ }^{(1)}$ A amostra com $15 \%$ teórico de fibra de vidro, apresentou teor real de $20 \%$. 


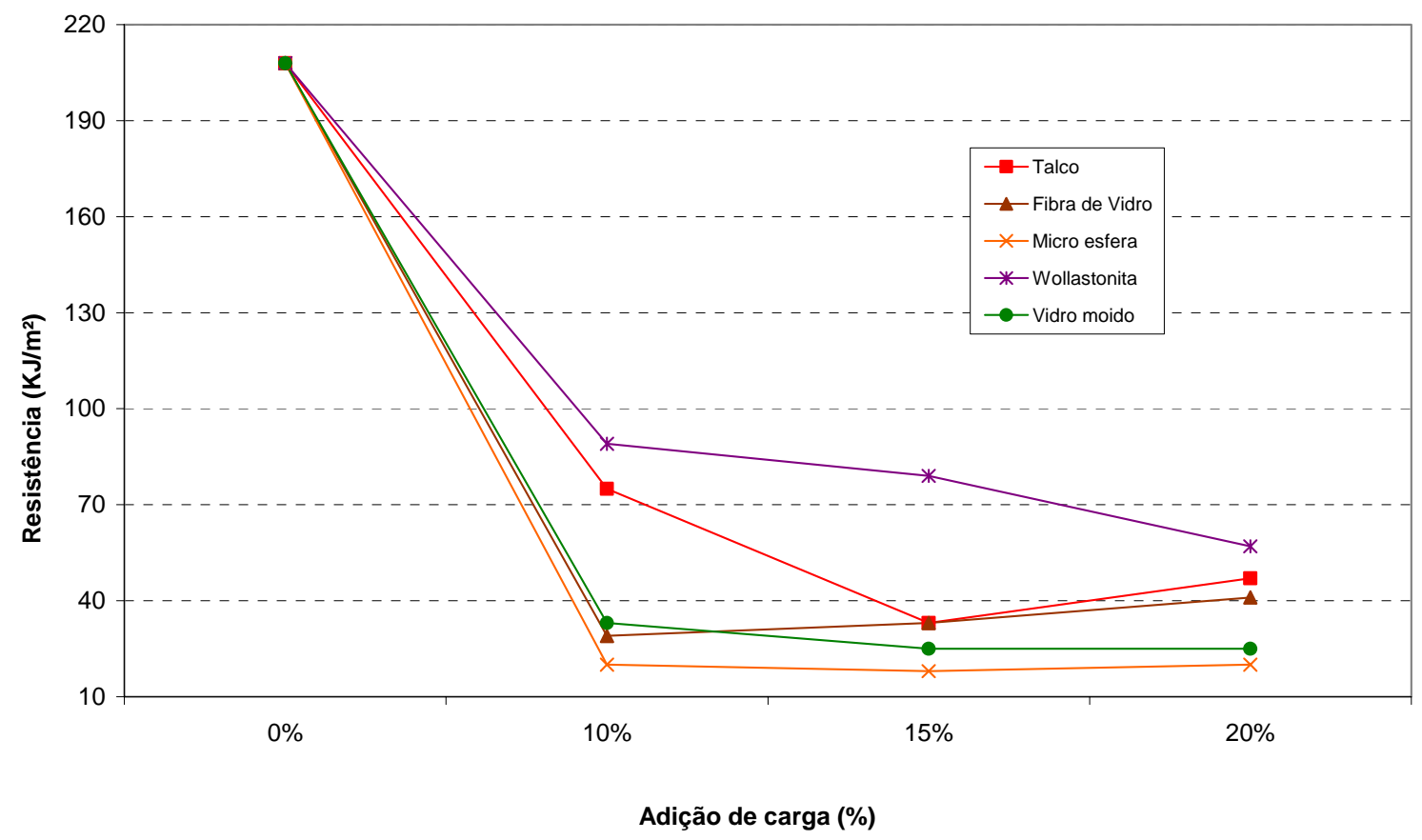

Figura 4.4: Representação da resistência ao impacto Charpy sem entalhe $\left(\mathrm{KJ} / \mathrm{m}^{2}\right)$.

Conforme já discutido no capítulo 2, a adição de cargas na poliamida produz compósitos com menores valores de resistência ao impacto. Este fenômeno pode ser explicado pelo fato de que as partículas não fibrosas funcionam como concentradores de tensão. A partir de um determinado valor de tensão, dependente da força das ligações na interface, a matriz começa a se separar da superfície da carga, criando vazios que passam a atuar como trincas na concentração de tensões até a sua propagação e efetiva fratura.

Neste estudo, porém mesmo os compósitos com fibra de vidro apresentaram este efeito, o que pode ser devido à redução do comprimento das fibras durante o processamento Já a poliamida 6.6 sem carga apresenta valores acima daqueles apresentados pelos compósitos.

A partir dos resultados verifica-se que a adição de teores diferentes de vidro moído à poliamida 6.6 praticamente manteve a resistência ao impacto apresentando-se pouco superior aos valores obtidos para a micro esfera de vidro. Para o talco observa-se um comportamento não linear, o que pode indicar problemas de dispersão nesta carga. 


\subsubsection{Estabilidade dimensional}

As Tabelas 4.8 e 4.9 apresentam os resultados obtidos para os compósitos com teores de adição de 10\%, 15\% e 20\% para cada uma das cargas, em comparação com o polímero sem carga, na determinação da estabilidade dimensional (contração) paralela e perpendicular ao fluxo de injeção e as Figuras 4.5 e 4.6 os gráficos que representam os comportamentos verificados neste estudo.

Tabela 4.8: Estabilidade dimensional média paralela ao fluxo (\%)

\begin{tabular}{|c|c|c|c|c|c|c|}
\hline $\begin{array}{l}\text { Teor } \\
(\%)\end{array}$ & $\begin{array}{l}\text { Sem } \\
\text { carga }\end{array}$ & Talco & $\begin{array}{l}\text { Fibra de } \\
\text { Vidro }^{(1)}\end{array}$ & $\begin{array}{c}\text { Micro } \\
\text { esfera de } \\
\text { Vidro }\end{array}$ & Wollastonita & $\begin{array}{l}\text { Vidro } \\
\text { Moído }\end{array}$ \\
\hline 0 & $2,7 \pm 0,1$ & ----- & ---- & ---- & ----- & ----- \\
\hline 10 & & $1,6 \pm 0,1$ & $0,9 \pm 0,1$ & $2,5 \pm 0,1$ & $2,1 \pm 0,1$ & $2,3 \pm 0,1$ \\
\hline 15 & & $1,5 \pm 0,1$ & $0,7 \pm 0,1$ & $2,5 \pm 0,1$ & $1,8 \pm 0,1$ & $2,3 \pm 0,1$ \\
\hline 20 & & $4,2 \pm 1,5$ & $0,7 \pm 0,2$ & $2,4 \pm 0,1$ & $1,5 \pm 0,1$ & $2,2 \pm 0,1$ \\
\hline
\end{tabular}

(1) A amostra com $15 \%$ teórico de fibra de vidro, apresentou teor real de $20 \%$.

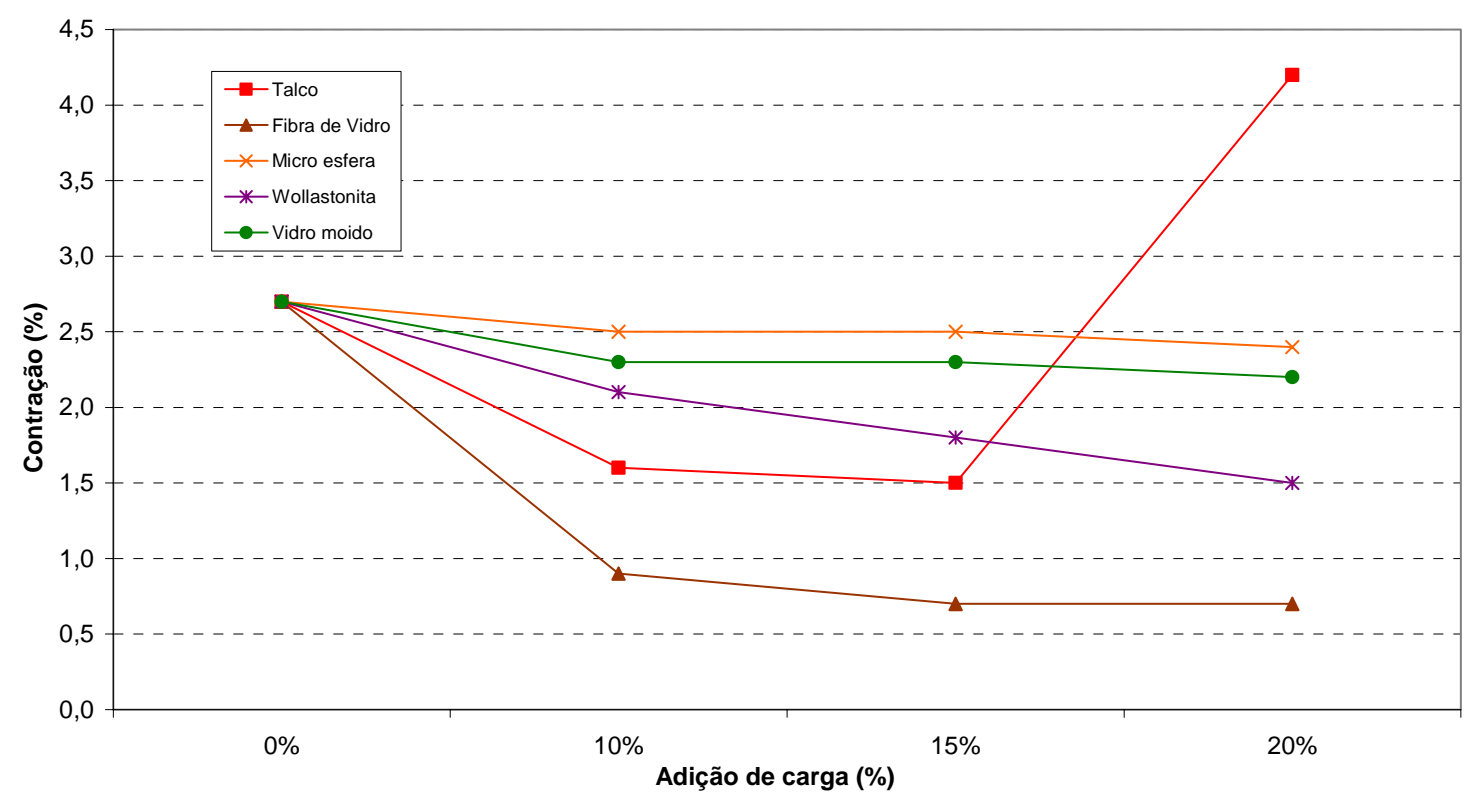

Figura 4.5: Representação da estabilidade dimensional média paralela ao fluxo (\%) 
Avaliando-se os resultados apresentados na Figura 4.5, verifica-se que os compósitos formados a partir da adição de micro esfera de vidro, e vidro moído apresentam redução da contração com o aumento do teor. O mesmo comportamento, porém mais acentuado observa-se para aqueles formados a partir da adição de fibra de vidro e de wollastonita. Já para o compósito com 20\% de talco observa-se um ponto discrepante que pode ser atribuído a um problema na medição e não na preparação, pois este efeito não se observa na Figura 4.6.

Tabela 4.9: Estabilidade dimensional média perpendicular ao fluxo (\%).

\begin{tabular}{|c|c|c|c|c|c|c|}
\hline $\begin{array}{l}\text { Teor } \\
(\%)\end{array}$ & $\begin{array}{l}\text { Sem } \\
\text { carga }\end{array}$ & Talco & $\begin{array}{l}\text { Fibra de } \\
\text { Vidro }^{(1)}\end{array}$ & $\begin{array}{c}\text { Micro } \\
\text { esfera de } \\
\text { Vidro }\end{array}$ & Wollastonita & $\begin{array}{l}\text { Vidro } \\
\text { Moído }\end{array}$ \\
\hline 0 & $2,8 \pm 0,1$ & ---- & ---- & ---- & ---- & ---- \\
\hline 10 & & $1,7 \pm 0,1$ & $1,9 \pm 0,1$ & $2,5 \pm 0,1$ & $2,2 \pm 0,1$ & $2,5 \pm 0,1$ \\
\hline 15 & & $1,6 \pm 0,1$ & $1,8 \pm 0,1$ & $2,6 \pm 0,1$ & $2,1 \pm 0,0$ & $2,4 \pm 0,1$ \\
\hline 20 & & $1,5 \pm 0,1$ & $1,7 \pm 0,1$ & $2,4 \pm 0,1$ & $2,0 \pm 0,1$ & $2,4 \pm 0,1$ \\
\hline
\end{tabular}

(1) A amostra com $15 \%$ teórico de fibra de vidro, apresentou teor real de $20 \%$.

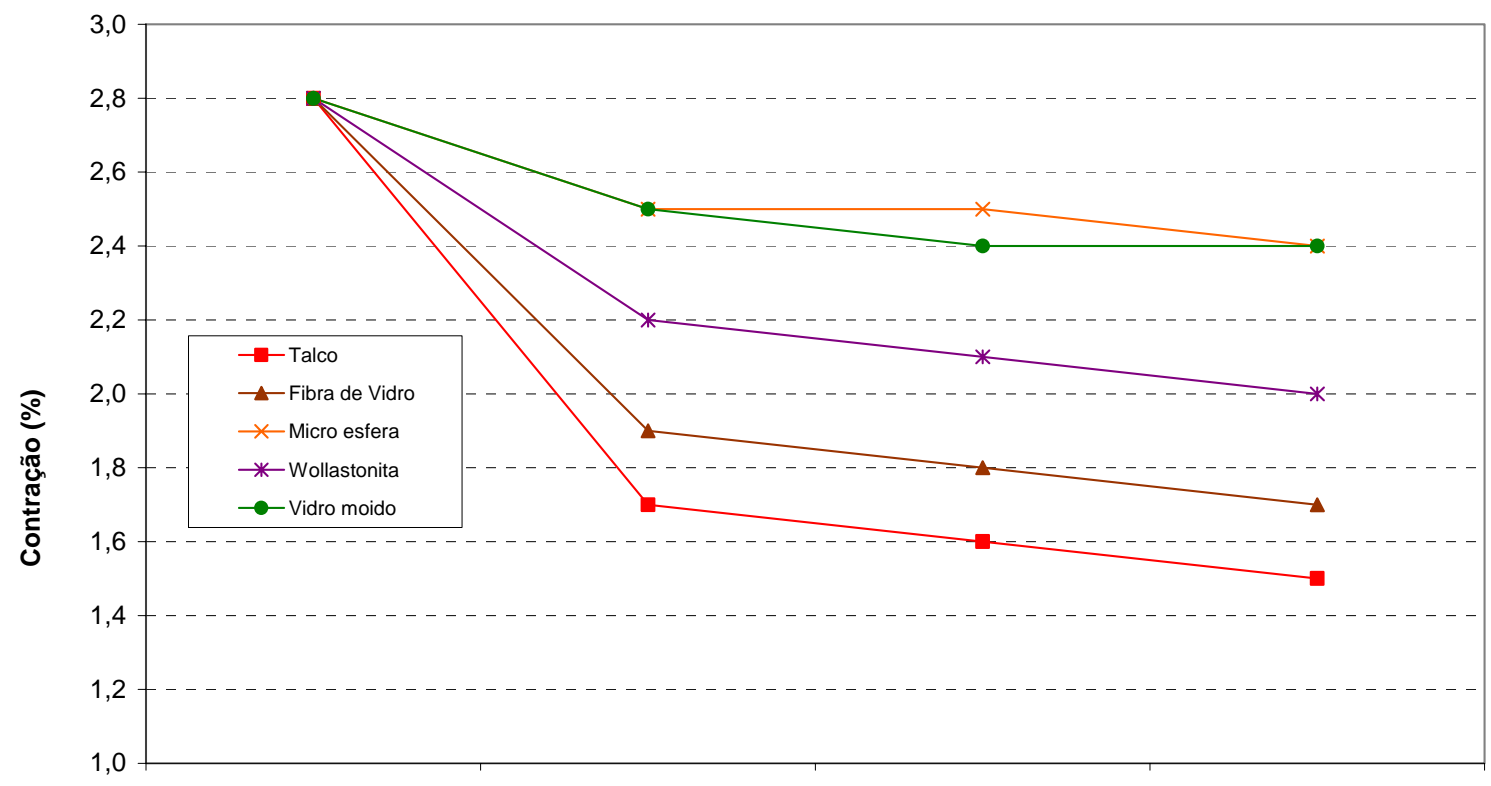

Adição de carga (\%)

Figura 4.6: Representação da estabilidade dimensional média perpendicular ao fluxo (\%). 
Para uma avaliação do comportamento de estabilidade dimensional se faz necessária a verificação da contração obtida no sentido paralelo ao fluxo e perpendicular ao fluxo, uma vez que quanto menor a diferença entre estas medidas maior será a estabilidade dimensional. Com base no exposto, pode-se afirmar que os compósitos que apresentam melhor estabilidade dimensional são aqueles à base de micro esfera de vidro e vidro moído. 


\subsubsection{Microscopia Eletrônica de Varredura (MEV).}

Todas as avaliações foram realizadas nos compósitos com 15\% de cada reforço para efeito de comparação e as Figuras 4.7, 4.8, 4.9, 4.10 e 4.11 apresentam as micrografias obtidas.

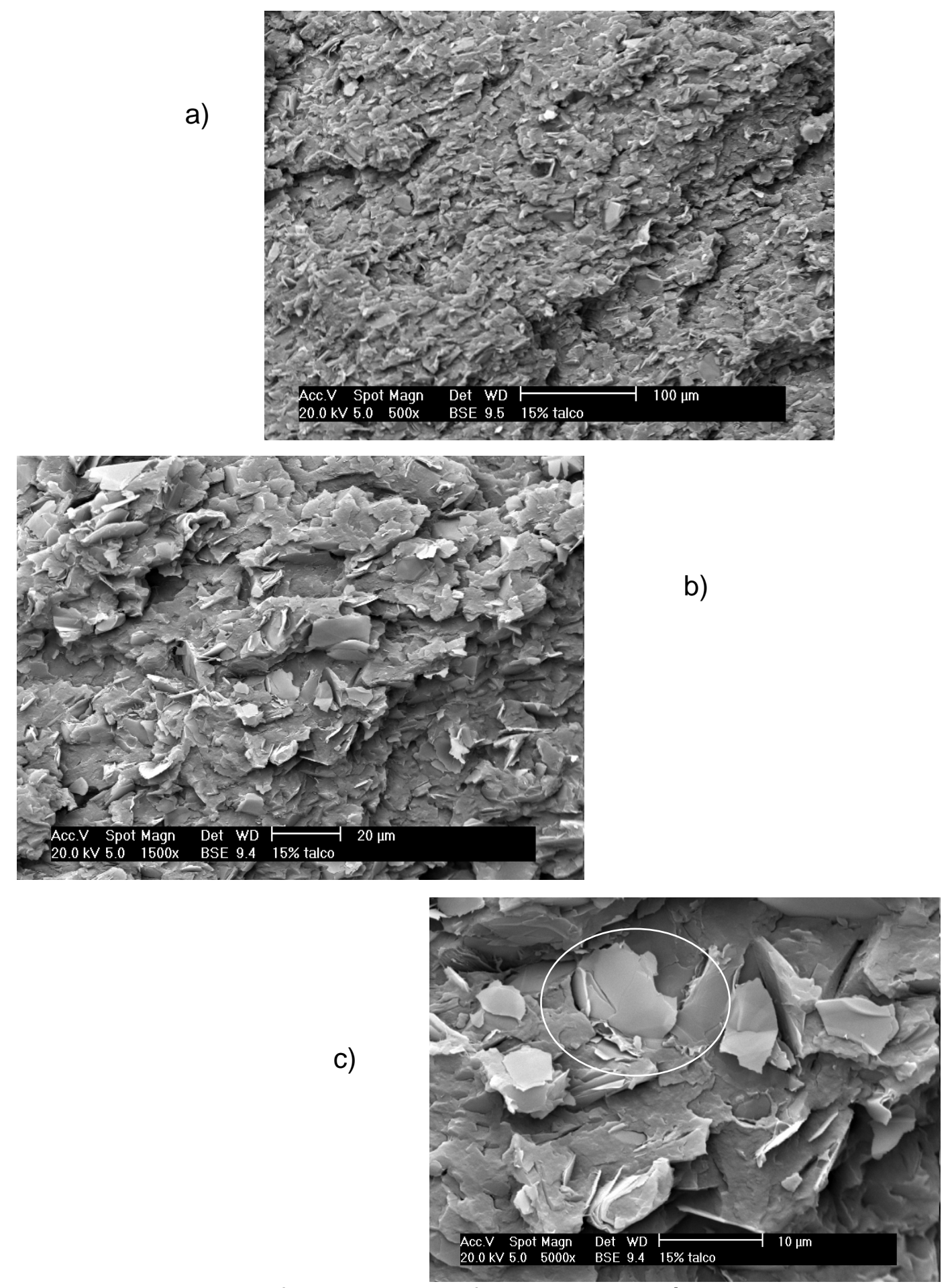

Figura 4.7: Micrografia por MEV da fratura do compósito de poliamida $6.6 \mathrm{com}$ 15\% de talco: a) ampliação de 500x; b) ampliação de 1500x; c) ampliação de 5000x com destaque para a observação de boa compatibilidade entre a matrizcarga 

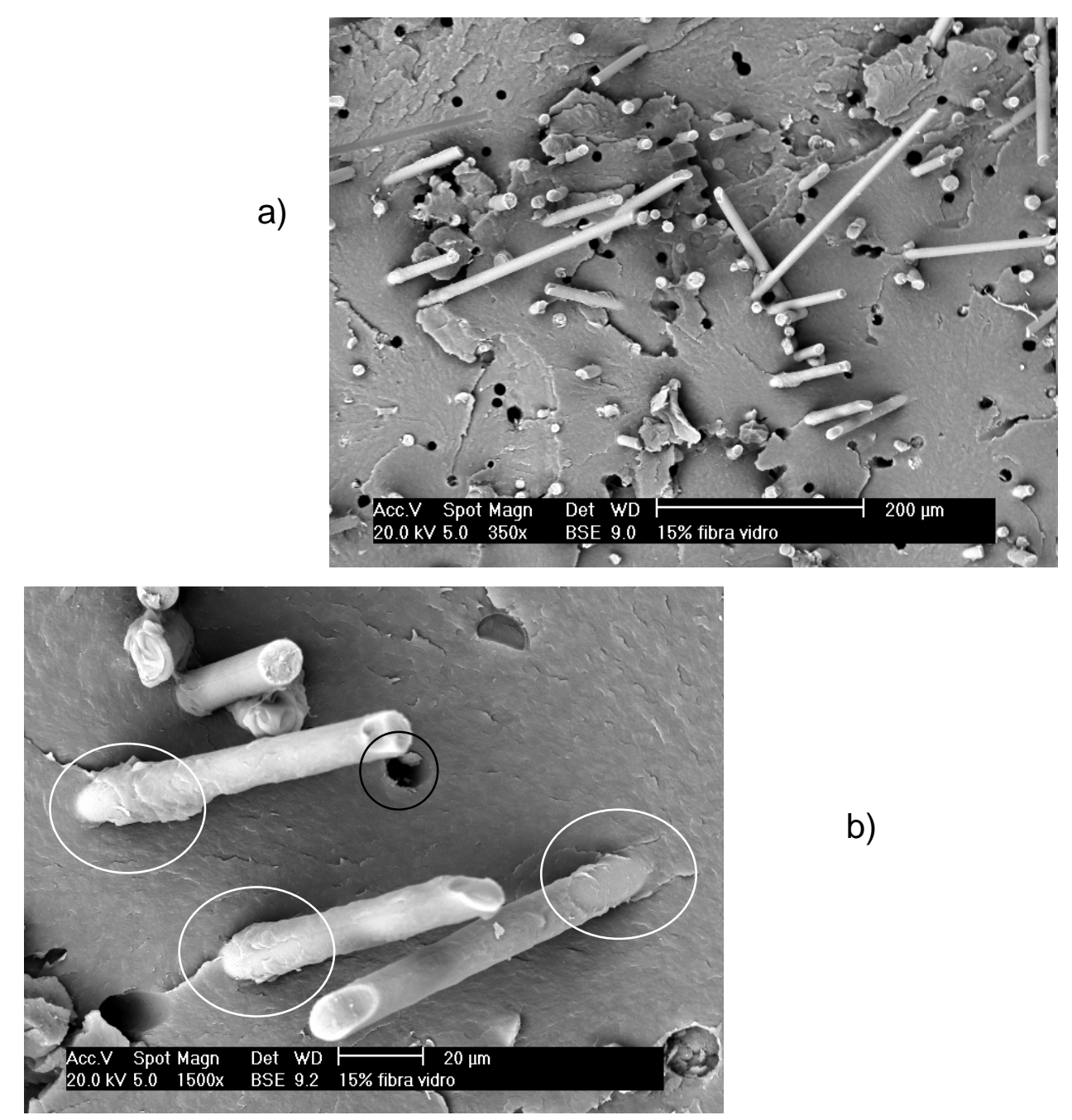

b)

c)

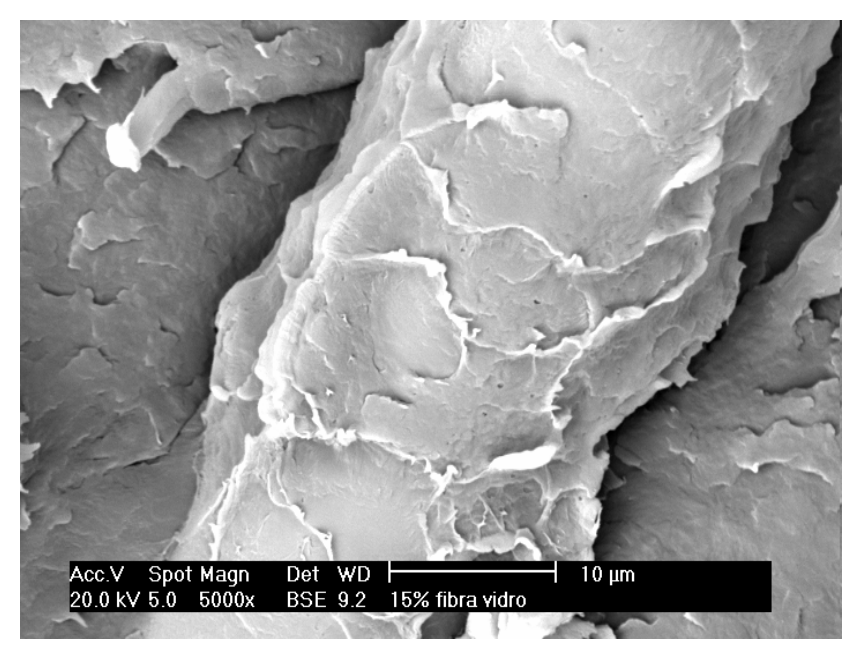

Figura 4.8: Micrografia por MEV da fratura do compósito de poliamida 6.6 com 15\% de fibra de vidro: a) ampliação de 350x; b) ampliação de 1500x com destaque para a retirada da fibra ("fiber-pullout") no momento da fratura; $c$ ) ampliação de 5000x com destaque para a observação de boa compatibilidade entre a matriz-carga 
a)
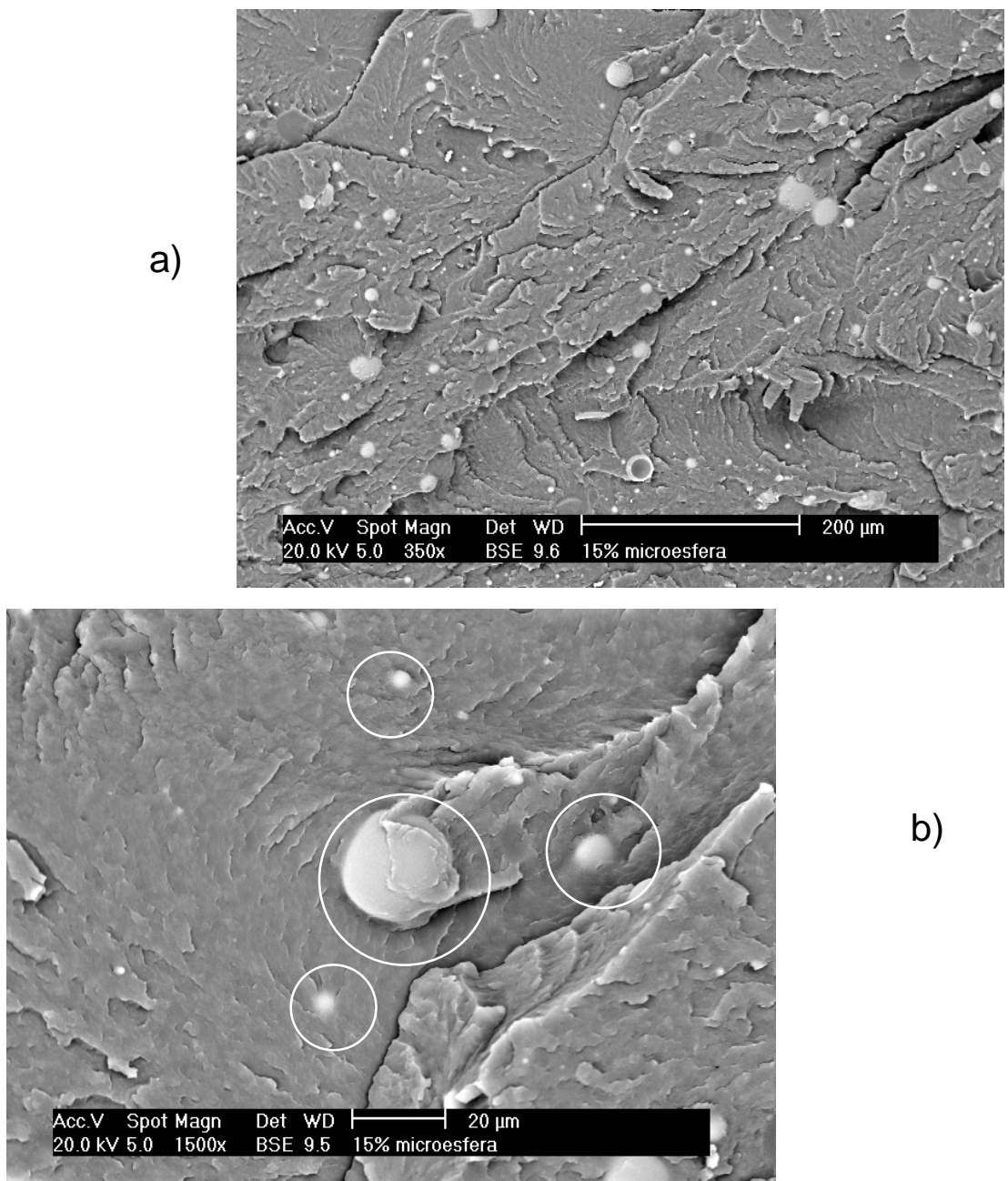

b)

c)

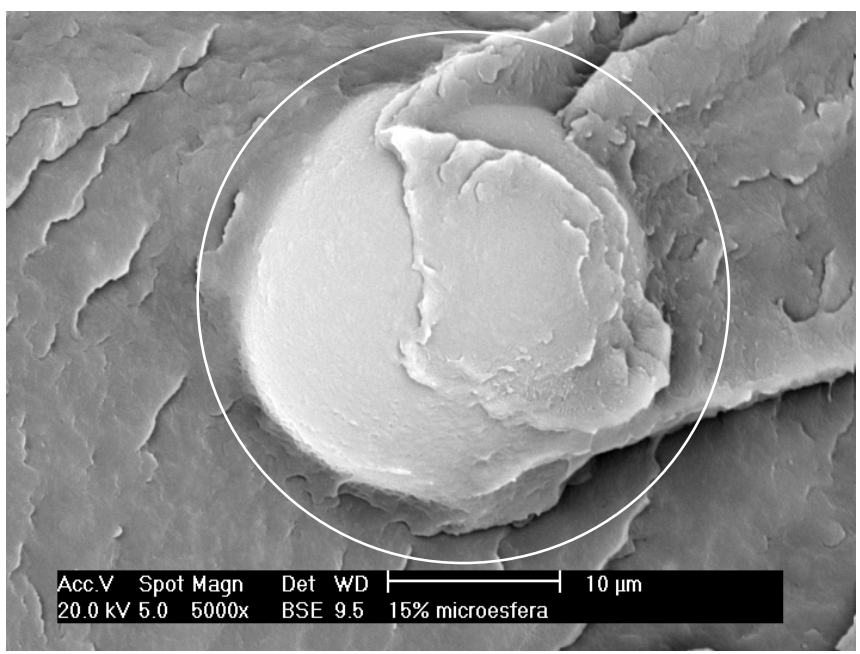

Figura 4.9: Micrografia por MEV da fratura do compósito de poliamida $6.6 \mathrm{com}$ 15\% micro esfera de vidro: a) ampliação de 350x; b) ampliação de 1500x; c) ampliação de 5000x com destaque para a observação de boa compatibilidade entre a matriz-carga 
a)
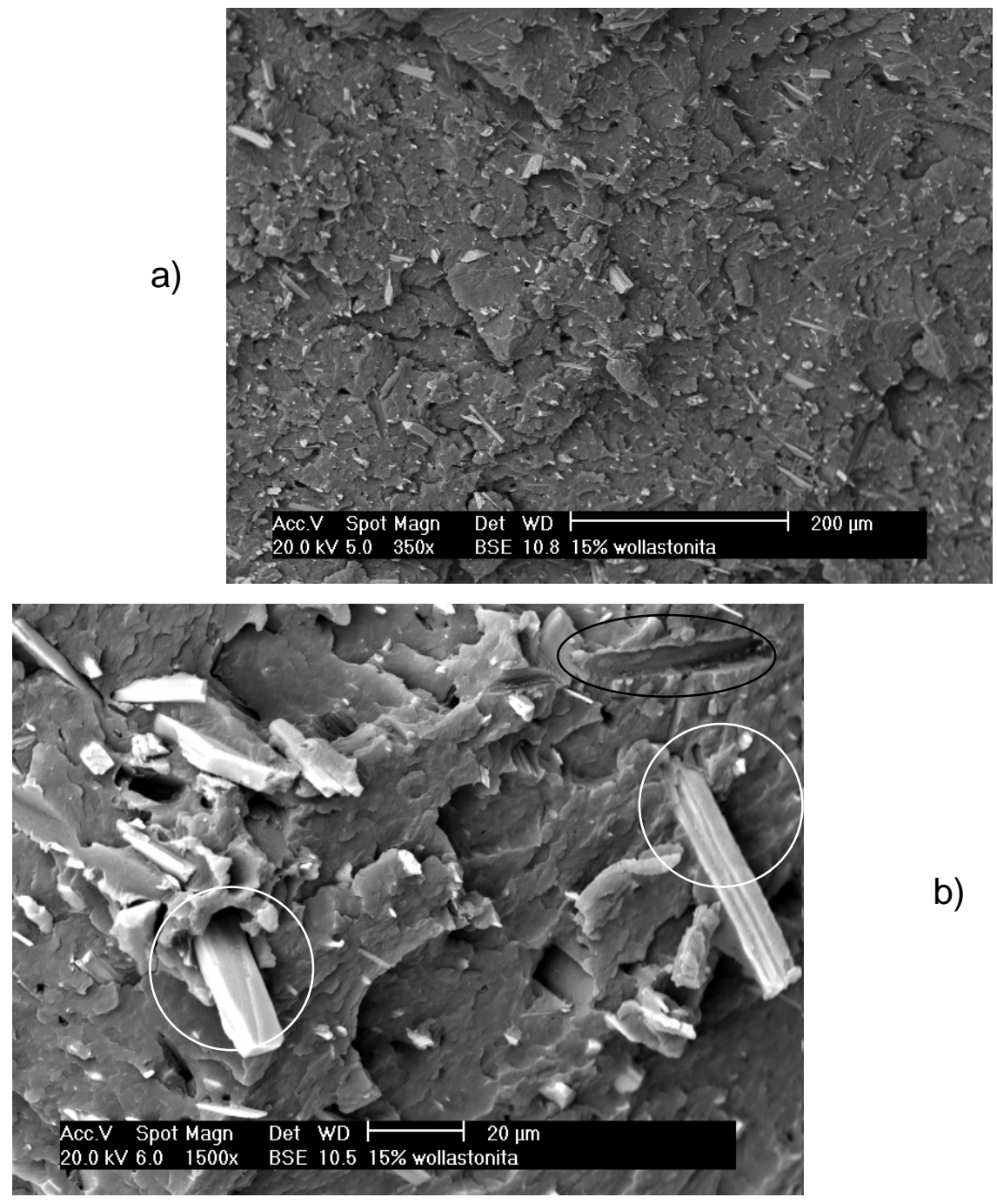

b)

c)

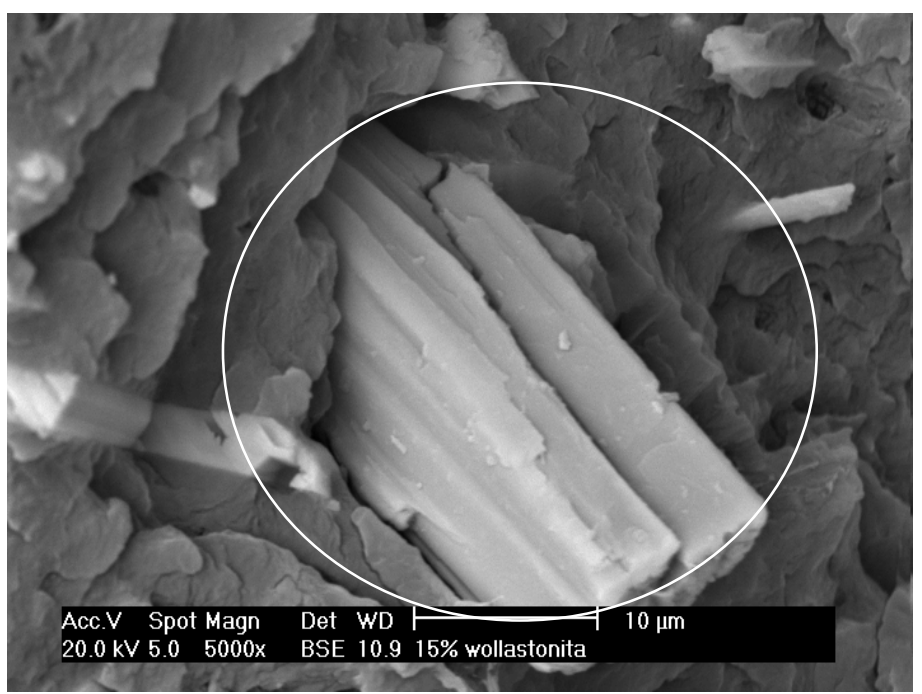

Figura 4.10: Micrografia por MEV da fratura do compósito de poliamida $6.6 \mathrm{com}$ 15\% wollastonita: a) ampliação de 350x; b) ampliação de 1500x; c) ampliação de 5000x com destaque para a observação de ausência de boa compatibilidade entre a matriz-carga 

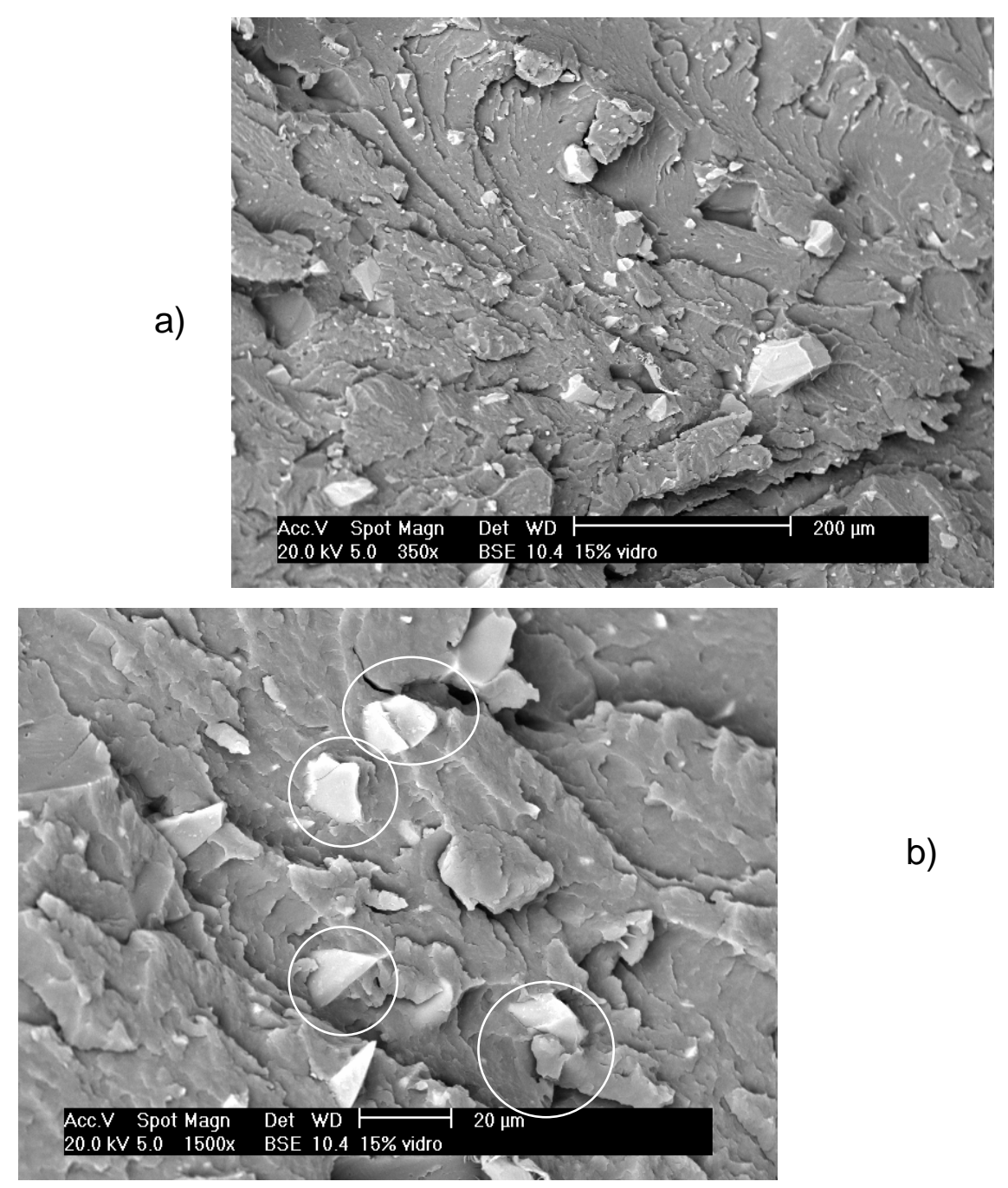

b)

c)

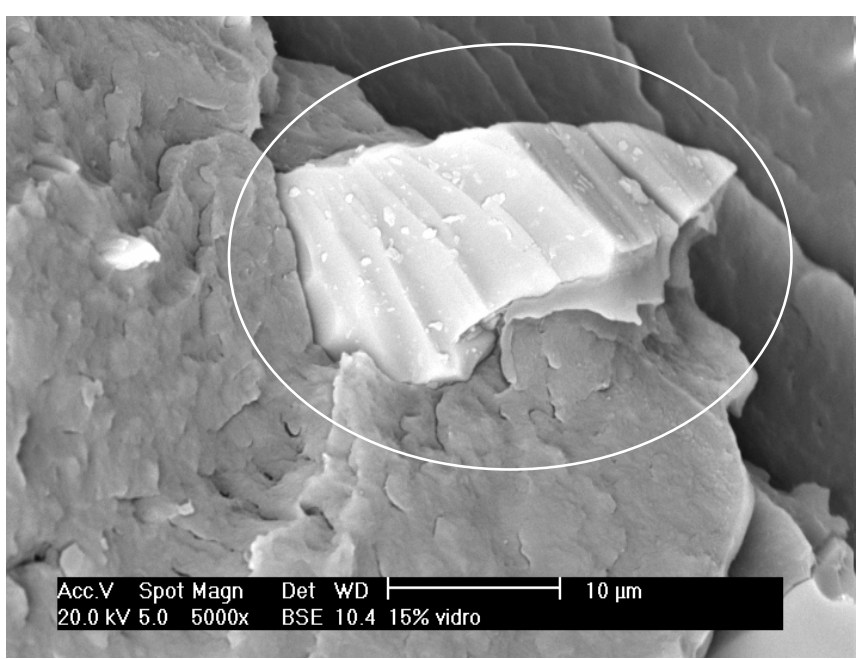

Figura 4.11: Micrografia por MEV da fratura do compósito de poliamida $6.6 \mathrm{com}$ 15\% vidro moído: a) ampliação de 350x; b) ampliação de 1500x; c) ampliação de 5000x com destaque para a observação de boa compatibilidade entre a matriz-carga

A análise das micrografias por MEV mostra uma melhor adesão da matriz e a fibra de vidro, mesmo com a presença do efeito "fiber-pullout", matriz e micro esfera de vidro, quando comparada com a matriz e wollastonita. $\mathrm{O}$ 
compósito com vidro moído apresenta boa compatibilidade entre matriz e reforço, mesmo sem o tratamento superficial com agente de acoplagem. 


\section{CONCLUSÕES}

Com base no comportamento mecânico e nas condições de processamento por extrusão e por injeção dos compósitos com diferentes teores de vidro reciclado (pó de vidro) pode-se afirmar que é possível fabricar compósitos com um conjunto interessante de propriedades com teores de carga da ordem de $10 \%$, em peso. Teores menores apresentaram dificuldade de processamento e teores maiores podem resultar em redução em algumas das propriedades.

O compósito obtido com vidro nos teores contemplados neste estudo apresenta propriedades mecânicas em faixas de valores comparáveis às cargas como talco, micro esfera de vidro e wollastonita. Em propriedades tais como resistência ao impacto, módulo de elasticidade e alongamento na ruptura, o compósito contendo vidro em pó apresenta desempenho superior àquele demonstrado pelas formulações contendo micro esferas de vidro, mesmo considerando-se que as micro esferas possuem tratamento superficial adequado para formar compósito com a matriz polimérica, poliamida 6.6. 


\section{REFERÊNCIAS BIBLIOGRÁFICAS}

[1] CALLISTER JR.,W.D Ciência e engenharia de materiais. Uma introdução, 5 ed., Rio de Janeiro; LTC, 589p, 2002.

[2] JORDAN, J.; JACOB, K.; TANNENBAUM, R.; SHARAF, A. M.; JASIUK, I.: Experimental trends in polymer nancomposites - a review. Materials Science and Engineering, A 393, p. 1-11, 2005.

[3] PADILHA, A.F. Materiais de engenharia: Microestrutura e propriedades, São Paulo, Helmus, 343p, 1997.

[4] CONTANT, S.; LONA, L. M. F: Predição do comportamento térmico de tubos compósitos através de redes neurais. Polímeros: ciência e tecnologia, vol. 14, n5, p. 295-300, 2004.

[5] OTA, W. N. Análise de compósitos de polipropileno e fibras de vidro utilizadas pela indústria automotiva nacional. 2004. Dissertação (mestrado) - Universidade Federal do Paraná.

[6] ALVES, O. L.; GIMENEZ, I.F.; MAZALL, I. O.; Vidros. Cadernos temáticos de química nova na escola, p. 13-24, 2001.

[7] MERCIER, J. P.; KURZ, W.; ZAMBELLI, G. Introduction à la science des matériaux. 3 ed., PPUR presses polytechniques, 499p, 1999.

[8] ASSIS, O. B. G.: O uso do vidro reciclado na confecção de membranas para micro filtração. Cerâmica, 52, p. 105-113, 2006.

[9] VIDRO. Disponível em <http://www.cebrace.com.br>. Acesso em 12 fev. 2009.

[10] LUCAS, E. F.; SOARES, B. G.; MONTEIRO, E. E. C. Caracterização de polímeros: determinação de peso molecular e análise térmica. Rio de Janeiro. e-papers, 366p, 2001.

[11] MERCIER, J. P.; MARÉCHAL, E. Chimie des polymères : synthèses, réactions, dégradations. PPUR presses polytechniques, 448p, 1993.

[12] HARPER, C. A. Handbook of plastics, elastomers and composites. 4 ed. New York, McGraw- Hill Companies Ltd, 884p, 2002.

[13] JOHNSON, W. A. Invitation à la chimie organique. De Boeck Université, $784 p, 2002$.

[14] BILLMEYER JR., F. W. Textbook of polymer science. 3 ed., New York: John Wiley \& Sons, 578p, 1984

[15] PAINTER, P. C.; COLEMAN, M. M.; IRUIN, J. J; BERRIDI, M. J. F. Fundamentals de ciencia de polímeros. CRC Press, 473p. 1996. 
[16] LISBÃO, A. S. Estrutura e propriedade dos polímeros. São Carlos, EdUFSCar, 168p, 2002.

[17] MURASE, S.; INOUE, A.; MYASHITA, Y.; KIMURA, N.: Structural characteristics and moisture sorption behavior of nylon 6/Clay hybrid films. Journal of polymer science, part B: polymer physics, vol. 40, p. 479-487, 2002.

[18] BASSANI, A.; PESSAN, L. A.; HAGE JR., E.: Propriedades Mecânicas de Blendas de Nylon-6/ Acrilonitrila-EPDM-Estireno (AES) Compatibilizadas com Copolímero Acrílico Reativo (MMA-MA). Polímeros: ciência e tecnologia, vol. 12, n², p. 102-108, 2002.

[19] HUANG, X.; LI, B.; SHI, B.; LI, L. : Investigation on interfacial interaction of flame retarded and glass fiber reinforced PA 66 composites by IGC/DSC/SEM. Polymer, 49, p 1049-1055, 2008.

[20] MITSUBISHI GAS CHEMICAL COMPANY, INC. K. Tanaka. Solid-phase drying and solid-phase polymerization of polyamide. EP 1347007 A1, 24 sept. 2003.

[21] AGUIAR, G. I. L.; YOSHIDA, I. V. P.: Modificação da poliamida $6.6 \mathrm{com}$ aminossilicona. Anais do $7^{\circ}$ congresso brasileiro de polímeros, 9-13 novembro, 2003, Belo Horizonte, MG, 1 CD-ROM.

[22] DASGUPTA, S.; HAMMOND, W. B.; GODDARD, W. A.: Crystal structures and properties of nylon polymers from theory. Journal of American Chemical Society, 118, p. 12291-12301, 1996.

[23] HUANG, L.; YUAN, Q.; JIANG, W. ; AN, L. ; JIANG, S. : Mechanical and thermal properties of glass bead-filled nylon-6. Journal of Applied Polymer Science, Vol. 94, p. 1885-1890, 2004.

[24] L. BRUEGGEMANN KG SPRIT-UND CHEMISCHE FABRIK. D. Lehmann; K. Titzschkau. Process for the condensation of polyamides. US 7005481 B1, 11 jun. 2002.

[25] GASPARIN, A. L. Comportamento mecânico de polímero termoplástico para aplicação em engrenagem automotiva. 2004. Dissertação (mestrado) Universidade Federal do Rio Grande do Sul.

[26] FERRO, W. P.; SILVA, L. G. A.; WIEBECK, H.: Uso da cinza da casca de arroz como carga em matrizes de poliamida 6 e poliamida 6.6. Polímeros: Ciência e Tecnologia, vol. 17, nº 3, p. 240 - 243, 2007.

[27] POLIAMIDA 6.6. Disponível em <http://www.fei.edu.br/textil/webdesign/htm/poliamida66.htm>. Acesso em: 28 jan. 2009. 
[28] KOHAN, M.I.; Nylon Plastics Handbook. Hanser\&Gardner Publications Inc., New York, 631p, 1995.

[29] HEYMANS, N.; SCHMELING, HH. KB.; KAUSCH,H.; PLUMMER, CJ.; DECROLY, $P$. Matériaux polymères: propriétés mécaniques et physiques. PPUR presses polytechniques, 657p, 2001.

[30] COMBETTE, P. ; ERNOULT, I. Physique des polymères : structure, fabrication, emploi. Presses International Polytechnique, 2005.

[31] CIMINELLI, R. R.: Caracterização das propriedades físicas, químicas e estruturais do talco em compostos termoplásticos. $4^{\circ}$ CONGRESSO BRASILEIRO DO PLÁSTICO REFORÇADO, 20-21 maio, 1986, São Paulo.

[32] PONTES, I. F.; ALMEIDA, S. L. M. Rochas \& Minerais Industriais: Usos e Especificações, Talco. 1 ed., Rio de Janeiro: Edil Artes Gráficas, v. 01, p. 607-628, 2005.

[33] CAMARA, A. L. Uso de talco nacional como aditivo adsorvente de piches e materiais pegajosos no processo de fabricação do papel. 2003. Dissertação (mestrado) - Universidade Federal de Minas Gerais.

[34] CAMPOS, L. E. G.; Talco e Pirofilita. Balanço Mineral Brasileiro, 2001.

[35] DALPIAZ, G. Estudo do efeito de cargas minerais em compósitos poliméricos particulados em matriz de polipropileno. 2006. Tese (Doutorado) - Universidade Federal do Rio Grande do Sul.

[36] HOLLAWAY, L. Handbook of Polymer Composites for Engineers. Woodhead Publishing, 338p, 1994.

[37] LIN, T.; JIA, D.; WANG, M.; HE, P.; LIANG, D.: Effects of fibre content on mechanical properties and fracture behavior of short carbon fibre reinforced geopolymer matrix composites. Bull. Mater. Sci., Vol. 32, nº 1, p. 77-81, 2009.

[38] FONSECA, S. B. C.; Materiais compósitos de matriz polimérica reforçada com fibras usados na engenharia civil: Características e aplicações. ITMC 35; LNEC, Lisboa, 2005.

[39] ROY, R.; SARKAR, B. K.; BOSE, N. R.: Effects of moisture on the mechanical properties of glass fibre reinforced vinylester resin composites. Bull. Mater. Sci, Vol. 24, nº1, p. 87-94, 2001.

[40] DE, S. K.; WHITE, J. R. Short Fibre-polymer Composites. Woodhead Publishing, 260p, 1996.

[41] LI, L.; LI, B.; TANG, F.: Influence of maleic anhydride-grafted EPDM and flame retardant on interfacial interaction of glass fiber reinforced PA-66. European Polymer Journal, 43, p. 2604-2611, 2007. 
[42] LEE, S. M. Handbook of Composite Reinforcements. John Wiley \&Sons, New York, 715p, 1992.

[43] OREFICE, R.; HENCH, L. L.; BRENNAN, A. B.: Effect of particle morphology on the mechanical and thermo-mechanical behavior of polymer composites. J. Braz. Soc. Mech. Sci., v.23, nº 1, 2001.

[44] MICRO ESFERA DE VIDRO. Disponível em $<$ http://www.potterseurope.com>. Acesso em 28 jan. 2009.

[45] FERNANDES, A. A. Síntese de zeolitas e wolastonita à partir da cinza da casca do arroz. 2006. Tese (Doutorado) - Instituto de Pesquisas Energéticas e Nucleares, São Paulo.

[46] OHRING, M. Engineering materials science. Academic Press, 827p, 1995.

[47] CARTER, B. C.; NORTON, M. G. Ceramic Materials. Springer, p. 716, 2007

[48] COELHO, J. M.; SUSLICK, S. B.; SOUZA, M. C. A. F.: Uma abordagem da indústria do feldspato no Brasil. Cerâmica Industrial, 5 (1), 2000.

[49] MURRAY, G. T. Introduction to engineering materials: behavior, properties, and selection. CRC Press, 669p, 1993.

[50] ASHBY, M.; BRECHET, Y.; SALVO, L. Sélection des matériaux et des procédés de mise en oeuvre. PPUR presses polytechniques, 478 p, 2001.

[51] LIMA, R. M. R.; FILHO, E. R.: A reciclagem de materiais e suas aplicações no desenvolvimento de novos produtos: Um estudo de caso. $3^{\circ}$ CONGRESSO BRASILEIRO DE GESTÃO DE DESENVOLVIMENTO DE PRODUTO, 25-27 set., 2001, Florianópolis.

[52] TOFFOLI, S.M.; DEMARQUETTE, N. R. ; VALERA, T.S.: Reaproveitamento dos materiais provenientes da reciclagem de vidros laminados. $17^{\circ}$ ENCONTRO TÉCNICO ABIVIDRO, 5-6 abril, 2006, São Paulo.

[53] RECICLAGEM DE VIDRO. Disponível em <http://reciclaveis.com>. Acesso em 6 abr. 2009.

[54] ADAMS, D. F.; CARLSSON, L. A.; PIPES, B. R. Experimental characterization of advanced composite materials, 3 rd ed., CRC Press, 238 p, 2002.

[55] SURAMPADI, N. L.; RAMISETTI, N. K. ; MISRA, R. D. K. : On scratch deformation of glass fiber reinforced nylon 66. Materials Science and Engineering, A 456, p. 230-235, 2007. 
[56] GAY, D.; HOA, S. V.; TSAI, S. W. Composite materials: design and applications. 4 ed., CRC Press, 531p, 2003.

[57] FELTRAN, M. B. Compósitos de PVC reforçados com fibra de vidro: uso de técnicas de processamento convencionais da indústria brasileira. 2008, Dissertação (Mestrado) - Escola Politécnica da Universidade de São Paulo, São Paulo.

[58] SOUZA, M. R. Blenda de Poli(tereftalato de etileno) com Polietileno de baixa densidade. 2007, Dissertação (Mestrado) - Escola Politécnica da Universidade de São Paulo, São Paulo.

[59] A200 NATURAL. Disponível em <http://www.rhodia -ep.com.br>. Acesso em 18 março 2009.

[60] FICHA TÉCNICA FISQ 001/04 - Magnesita - Divisão de Minerais.

[61] FICHA TÉCNICA OWENS CORNING.

[62] WOLLASTONITA. Disponível em <http://www. nycominerals.com. Acesso em 18 março 2009.

[63] COMPOSIÇÃO QUÍMICA DO VIDRO. Disponível em <http://saint-gobainvidros.com.br>. Acesso em 20 março 2009.

[64] GRANUTEST. Disponível em <http://bertel.com.br>. Acesso em 20 março 2009.

[65] WAGNER, D. T.; ARANHA, I. B.: Método para análise de tamanho de partícula por espalhamento de luz para Bentonita Chocolate. XV JORNADA DE INICIAÇÃO CIENTÍFICA - CETEM, 2007, Rio de Janeiro.

[66] PROPRIEDADES MECÂNICAS. Disponível em < http://www.poliuretanos.com.br>. Acesso em 20 abril 2009.

[67] AMERICAN SOCIETY FOR TESTING AND MATERIALS. ASTM D-638: Standard Test Method for Tensile Properties of Plastics. Philadelphia, 1997.

[68] INTERNATIONAL ORGANIZATION FOR STANDARDIZATION. ISO 179: Plastics - Determination of Charpy impact strength. Genebra, 1993, 12 p.

[69] ROTHON, R. N., Mineral Fillers in Thermoplastics: Filler Manufactured and Characterization - Advances in polymer Sciences, New York, 139p, 1999.

[70] AMERICAN SOCIETY FOR TESTING AND MATERIALS. ASTM D-955: Standard Test Method of Measuring Shrinkage from Mold Dimensions of Thermoplastics, 2000, 5p. 
[71] INTERNATIONAL ORGANIZATION FOR STANDARDIZATION. ISO 2577: Plastics - Thermosetting moulding materials - Determination of shrinkage, 2007.

[72] RODRIGUES, A.; CASSEMIRO, A. B.; GUIRAO, A. Z.; SOCREPA, R. Estudo das propriedades mecânicas e térmicas de compósitos de PA 6.6 com micro esferas ocas de vidro e cerâmica. Monografia (TCC), Centro Universitário Fundação Santo André, 2008, Santo André.

[73] ODIAN, O. G; Principles of Polymerization, 4 rd Ed., John Wiley \& Sons Inc. Publication, 812 p, 2004.

[74] COELHO, A. C. V.; SANTOS, S. P: Argilas especiais: argilas quimicamente modificadas - uma revisão. Química Nova, v. 30. n. 5, p. 1282-1294, 2007.

[75] ZUMDAHL, S. S.; GAGNON, J. M.; ROUTEAU, M.; Chimie Générale, De Boeck Université, 512 p., 1999.

[76] ARKEMAN, M. Natureza, estrutura e propriedades do vidro. CETEVCentro Técnico de Elaboração do Vidro. São Paulo, 37 p., 2000.

[77] RABELO, M. Aditivação de Polímeros. São Paulo, Artliber Editora, 2000.

[78] FREIRE, E.; MONTEIRO, E. E. C; CYRINO, J. C. R.: Propriedades mecânicas de compósitos de polipropileno com fibra de vidro. Polímeros: Ciência e Tecnologia, p 25 - 32, jul/set-1994.

[79] BAILLON, J. P.; DORLOT, J. M.; Des matériaux. Presses Inter Polytechnique, 736 p., 2000. 